\title{
Genetic analysis of rainbow trout (Oncorhynchus mykiss): Strain identification via microsatellites and analysis of expressed sequence tags in intestine, liver, kidney, and ovary
}

\author{
Amanda B. Stewart
}

West Virginia University

Follow this and additional works at: https://researchrepository.wvu.edu/etd

\section{Recommended Citation}

Stewart, Amanda B., "Genetic analysis of rainbow trout (Oncorhynchus mykiss): Strain identification via microsatellites and analysis of expressed sequence tags in intestine, liver, kidney, and ovary" (2006). Graduate Theses, Dissertations, and Problem Reports. 4272.

https://researchrepository.wvu.edu/etd/4272

This Dissertation is protected by copyright and/or related rights. It has been brought to you by the The Research Repository @ WVU with permission from the rights-holder(s). You are free to use this Dissertation in any way that is permitted by the copyright and related rights legislation that applies to your use. For other uses you must obtain permission from the rights-holder(s) directly, unless additional rights are indicated by a Creative Commons license in the record and/ or on the work itself. This Dissertation has been accepted for inclusion in WVU Graduate Theses, Dissertations, and Problem Reports collection by an authorized administrator of The Research Repository @ WVU.

For more information, please contact researchrepository@mail.wvu.edu. 
Genetic Analysis of Rainbow Trout (Oncorhynchus mykiss):

Strain Identification via Microsatellites and Analysis of

Expressed Sequence Tags in Intestine, Liver, Kidney, and Ovary

Amanda B. Stewart

Dissertation submitted to the

College of Agriculture, Forestry and Consumer Sciences

at West Virginia University in partial fulfillment of the requirements

for the degree of

\author{
Doctor of Philosophy \\ In \\ Agricultural Sciences
}

\author{
Robert A. Dailey, Ph.D., Chair \\ Kenneth P. Blemings, Ph.D. \\ Patricia M. Mazik, Ph.D. \\ Caird E. Rexroad, III, Ph.D. \\ Daniel Panaccione, Ph.D. \\ Division of Animal and Veterinary Sciences \\ Morgantown, West Virginia \\ 2006
}

Keywords: Rainbow trout, microsatellite, expressed sequence tags

Copyright 2006 Amanda B. Stewart 


\title{
ABSTRACT \\ Genetic Analysis of Rainbow Trout (Oncorhynchus mykiss): Strain Identification via Microsatellites and Analysis of Expressed Sequence Tags in Intestine, Liver, Kidney, and Ovary
}

\begin{abstract}
Amanda B. Stewart
Implementation of modern fishing techniques and hatchery technologies necessitates use of genetics in management of fishery stocks. Genetic analysis of rainbow trout, Oncorhynchus mykiss, will assist development of superior strains of a valuable aquacultured species. This study was to (1) develop polymorphic microsatellite markers to examine for variation among rainbow trout strains and develop an identification panel of microsatellites to distinguish individual strains, and (2) to identify novel genes and estimate relative gene expression profiles (expressed sequence tags from rainbow trout liver, intestine, kidney, and ovary non-normalized libraries). Thirty-seven microsatellites were identified by screening 576 clones from TAGA and ATG-repeat enriched libraries. Allele frequencies were used to determine number of alleles per locus, percentage of variable loci, and mean heterozygosity, and calculation of F-statistics using GenePop and Bisosys software. Further analysis of ten individuals of ten strains with 13 markers was produced unique genotypes. Observed heterozygosity over all loci was less than the expected Hardy-Weinberg values. Mean $\mathrm{F}_{\mathrm{IS}}$ values were high in Wytheville and Ennis strains, suggestive of inbreeding. Between-strain heterogeneity tests were significant $(p<0.001)$ for all pair-wise comparisons of strains, thus each strain is considered unique. Allele frequencies allowed correct assignment of $92 \%$ of individuals to strain of origin. Analysis of expressed sequence tags identified 90, 8, 19, 47 previously unknown genes in intestine, liver, kidney, and ovary, respectively. Overall, Wytheville trout appear to be least diverse. Many genes were in more than one tissue, suggesting potential use as positive-controls in PCR-based studies in these tissues.
\end{abstract}




\section{TABLE OF CONTENTS}

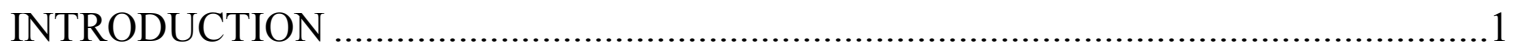

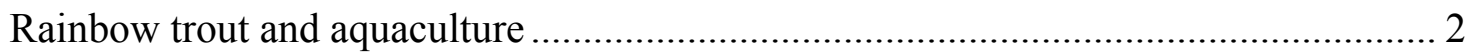

Origins and classifications of rainbow trout ......................................................... 2

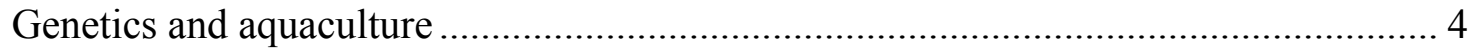

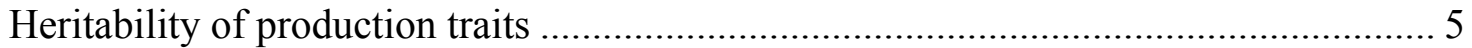

Negative effects of inbreeding .......................................................................... 7

Initial genetic analyses of salmonids ................................................................. 9

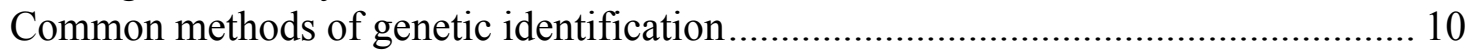

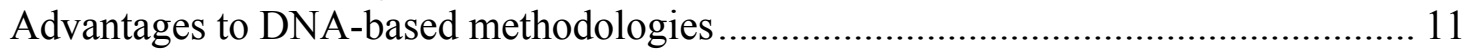

Microsatellites aid identification of quantitative trait loci...................................... 17

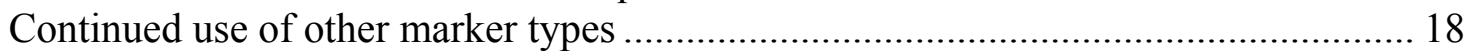

I. Use of Microsatellites for Strain Identification of Rainbow Trout .............................19

Identification and maintenance of wild, naturalized, and hatchery stocks .................. 22

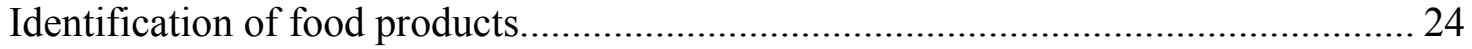

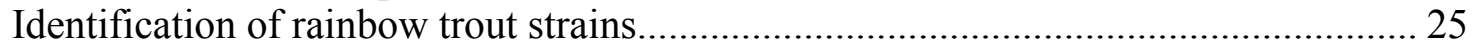

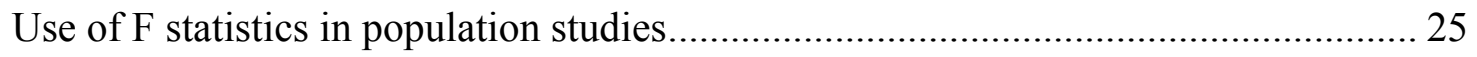

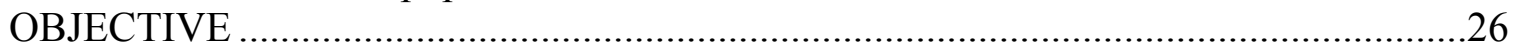

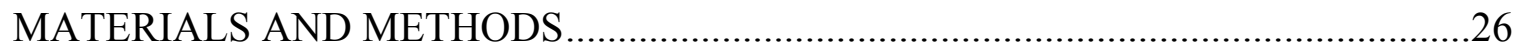

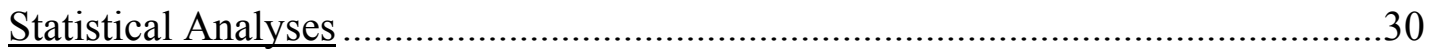

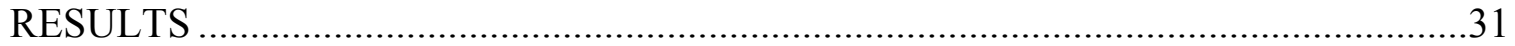

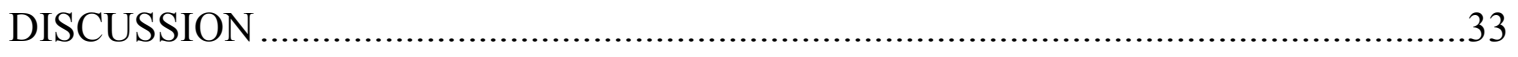

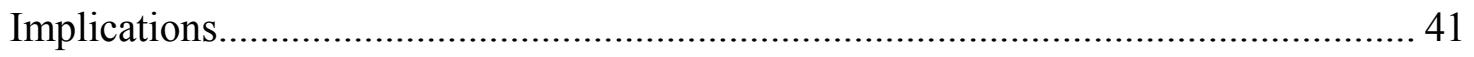

II. Gene Identification and Evaluation of Relative Gene Expression in Rainbow Trout (Oncorhynchus mykiss) Intestine, Liver, Kidney, and Ovary Using Expressed Sequence

Tags .43

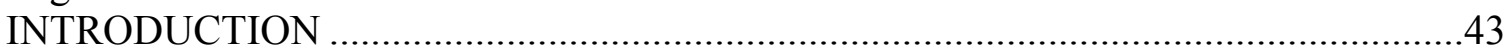

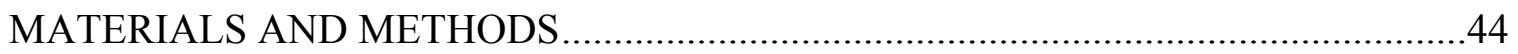

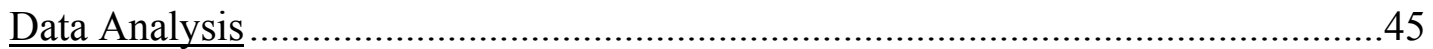

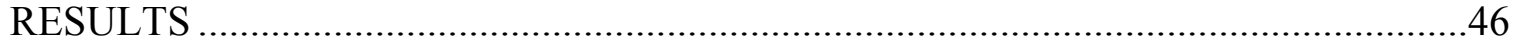

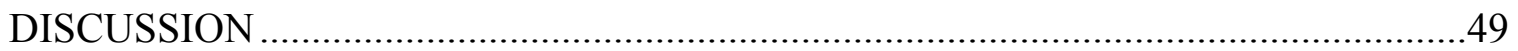

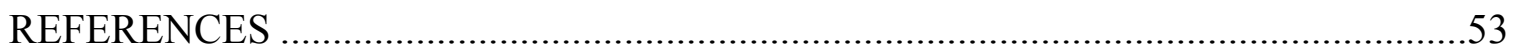




\section{LIST of TABLES}

Table 1. Species of Salmonidae, Fishery and Culture Status ........................................... 101

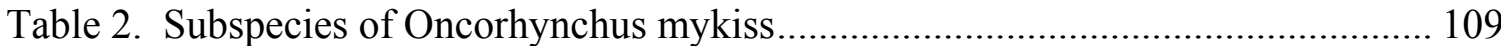

Table 3. A Survey of Literature of Genetic Analysis in Salmonids ............................. 110

Table 4. Strains of Rainbow Trout used in Microsatellite Analysis ............................... 128

Table 5. Microsatellites Identified in Rainbow Trout TAGA and ATG Repeat-Enriched

Libraries

Table 6. The Variety of Alleles Found at Each Microsatellite Locus in 10 Strains of

Rainbow Trout

Table 7. Strains of Rainbow Trout with Unique Alleles at Each Locus.

Table 8. Number of Alleles in Each Rainbow Trout Strain and Average Heterozygosity

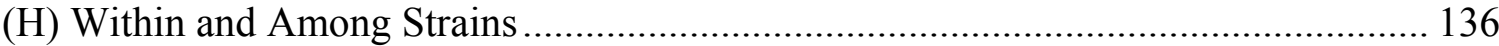

Table 9. Mean Heterozygosity Within Each Strain of Rainbow Trout.......................... 138

Table 10. F IS Values for Each Locus Within Each Strain of Rainbow Trout* ............... 139

Table 11. $\mathrm{F}_{\mathrm{IS}}, \mathrm{F}_{\mathrm{ST}}$, and $\mathrm{F}_{\mathrm{IT}}$ values for Each Microsatellite Locus .................................... 140

Table 12. Mean Strain $F_{I S}$ Values for Each Strain of Rainbow Trout ............................ 141

Table 13. Individual Rainbow Trout Assigned Incorrectly to Strain of Origin............. 142

Table 14. Genetic Differentiation (Pairwise F $_{\mathrm{ST}}$ ) Between Strains of Rainbow Trout.. 142

Table 15. Genetic Distance Between Strains of Rainbow Trout* ................................. 143

Table 16. Summary of BLAST Searches, Clustered Sequences, and Redundant Clones in

Rainbow Trout Expressed Sequence Tags..................................................................... 143

Table 17. Summary of Gene Classifications of Rainbow Trout Expressed Sequence Tags

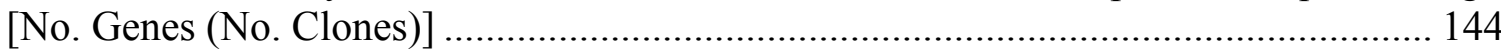

Table 18. Rainbow Trout Expressed Sequence Tags with Putative IDs Matching Other Species 145

Table 19. Expressed Sequence Tag Clones Found in Multiple Tissues of Rainbow Trout 


\section{LIST of FIGURES}

Figure 1. Genetic Distance Among Strains of Rainbow Trout

Figure 2. Number of Expressed Sequence Tag Clones in Identification Categories for Evaluated Tissue in Rainbow Trout.............................................................................. 148

Figure 3. Percentage of Expressed Sequence Tag Clones in Identification Categories for

Evaluated Tissue in Rainbow Trout..... 
APPENDICES

Appendix 1. Genotypes of Individual Rainbow Trout 


\section{INTRODUCTION}

Agricultural production must provide needed nutrients as the world's population increases. The majority of the world depends on fish as a primary food source of protein (Allendorf et al., 1987a). Aquaculture, cultivation of natural produce of water, has been practiced since $2500 \mathrm{BC}$ by the Chinese but did not gain heightened usage by the Western world until the 1960s. As most fish consumed by the human population are harvested from the declining world stocks (Allendorf, 1988; Allendorf et al., 1987a), vast increases in production of highquality protein from aquatic sources, particularly of species suitable for aquaculture (Dunhan et al., 2000), are essential in meeting the world's growing demand. The implementation of modern fishing techniques that severely reduced fish numbers and the development of hatchery technologies that resulted in largescale aquaculture for both re-stocking and human consumption (Allendorf et al., 1987b; Chapman and Mathisen, 1987) necessitate the use of genetics in the management of fishery stocks.

The family Salmonidae includes the genera Acantholingua, Brachymystax, Coregonus, Hucho, Oncorhynchus, Prosopium, Salmo, Salvelinus, and Thymallus (Frose and Pauly, 2005; Table 1). The family includes 190 species, 54 of which are harvested from wild fisheries (42 commercial, ten minor, two subsistence) and 31 are commercially produced (26 commercially, five experimentally). In addition, 42 species are popular gamefishes.

The genus Oncorhynchus contains nine species that are commercially harvested, six of which are designated "highly commercial," nine species that are 
commercially produced, and 12 that are gamefishes. Of these species, the rainbow trout, Oncorhynchus mykiss, has become a widely cultured, valuable species in the aquaculture industry due to ease of culture and transport (MacCrimmon, 1971), its adaptability to various aquatic environments (Ryman, 1983; Hershberger, 1992), and popularity with both anglers and consumers. Currently, there are ten recognized subspecies of rainbow trout (Table 2).

The National Agricultural Statistics Service 2005 report for Trout Production noted that the total value of sales for trout and eggs totaled 68.7 million dollars in 2004. In addition to trout sales, trout distributed by state and federal hatcheries totaled 64.8 million dollars. In West Virginia, there were 31 trout producers, 21 of whom reported selling trout, and 16 distributed trout for recreational or conservation purposes; total value of sold fish was $\$ 694,000$, and total value of distributed fish was $\$ 2,155,000$. For all values, both dollar value and numbers of producers increased from reported values in 2003.

\section{Rainbow trout and aquaculture}

\section{Origins and classifications of rainbow trout}

Rainbow trout are native to the Pacific Ocean, western North America, and northeastern Asia (Behnke, 1979; Bagley and Gall, 1998), and through widespread introduction has become the most common Salmonid world-wide (Hershberger, 1992). In the past, rainbow trout were classified as Salmo rivularis for anadromous steelhead trout, Salmo irideus for rainbow trout, and Salmo shasta for a hatchery strain of the original McCloud River rainbow (Kendall, 1920). Rainbow trout from differing habitats, which may have differed 
phenotypically, were classified as distinct species in many cases. Shortly thereafter, rainbow trout and steelheads were combined into a single classification, Salmo gairdneri, and subdivisions of the species were based on characteristics related to anadromous behavior (Withler, 1966; Millenbach, 1973).

Later, comparison of protein variants supported the division of rainbow trout located on the east versus the west side of the Cascade Mountains into two taxonomic groups; it was suggested that this was due to previous geographic isolation (Allendorf, 1975; Utter et al., 1980). Behnke (1979) cited morphological differences that further suggested that coastal and inland (redband) rainbow trout be classified separately as Salmo gairdneri and Salmo newberri, respectively. Genetic differences were shown between inland redband rainbow trout, and coastal rainbow trout (Gold and Gall, 1975; Berg and Gall, 1988; Reisenbichler and Phelps, 1989; Behnke, 1992; Nielsen et al., 1994; Busby et al., 1996). Data from other studies utilizing protein electrophoresis verified large differences between the two groups (Allendorf and Phelps, 1981). However, chromosomal variation data did not (Thorgaard, 1983a). Because further evidence supported that rainbow trout are more closely related to Pacific salmon (genus Oncorhynchus) than Atlantic salmon (genus Salmo), these fish were reclassified into a single species (Oncorhynchus mykiss; Smith and Stearley, 1989). The phylogenetic relationships of rainbow trout with other Oncorhynchus species were examined by Utter and Allendorf (1994), resulting in a consensus phylogenic tree. Following mitochondrial DNA (mtDNA) and single-copy 
nuclear (scnDNA) analysis, Bagley and Gall (1998) provided evidence to support the division of trout groups as (Table 2 subspecies of O. mykiss).

\section{Genetics and aquaculture}

Many studies have demonstrated the effects of genetics on a variety of production traits, including growth, survival, length, weight, lipid and dry matter content, disease resistance, and temperature tolerance (Table 3). Such studies have utilized a variety of methods, ranging from specific matings and maintenance of individual family groups to quantitative trait loci (QTL) studies, to examine genetic effects on production traits. Rainbow trout have been examined in a wide range of basic science studies, as reviewed by Thorgaard and et al. (2002). As an agricultural pursuit, the study of population genetics is necessary to prevent further damage to the world's fish supply, as proper management and enhancement of existing stocks and populations will require such knowledge (Ryman and Utter, 1987). Thus, the identification of genetic variability and population structure is of critical importance in maintenance of both wild (Blanco et al., 2005) and hatchery stocks (Hershberger, 1992). Hershberger (1992) stated that “...it is important to evaluate the current status of the variability in both the natural and hatchery populations in relation to past practices. Such information can be utilized in future stock development and conservation programs to design programs that will permit the best use of extant genetic resources." In addition, due to the wide variety of aquatic environments in which rainbow trout are successful, adaptation has produced a variety of 
phenotypes (Hershberger et al., 1992), many of which might be advantageous to trout producers.

\section{Heritability of production traits}

Although the general history of rainbow trout aquaculture is documented, Dollar and Katz (1964) cite "lack of information on the procedures used for hatchery broodstock development" as a difficulty in clearly determining the origins of aquacultured strains. Most strains of trout used in aquaculture were initially collected from the McCloud River in Baird, CA (Dollar and Katz, 1964), and a hatchery was established there in 1879 (Overturf et al., 2003). Reportedly, those trout adapted to harsh conditions (Nielsen et al., 1999), however that population is now considered a candidate for the endangered species list (Nature Serve, 2006). Hershberger (1992) reviewed the history of transplantation and hatchery strain development in this species, and it is interesting to note that the rainbow trout came to West Virginia from Wytheville, VA stocks. The Wytheville hatchery was one of the eight direct acquisitions of trout from McCloud River, Baird, CA. Broodstock for this strain were developed from the initial shipment of 25,000 eggs in 1882 and a later shipment of 82,000 eggs in 1883 from the Baird Hatchery, and eggs from Utah (1926) and Montana (1927) (Dollar and Katz, 1964).

Genetic selection of specific strains best suited for aquaculture shows great promise. For example, in selecting for increased growth rate, traditional agriculture species exhibit genetic variation of seven to ten percent, whereas, fish species exhibit variation ranging from 20 to $35 \%$ (Gjedrem, 1997); in some 
species it is even greater (Allendorf, 1988). In rainbow trout, within full-sib groups, distribution of body weight ranged from 1.2 to $3.6 \mathrm{~kg}$ (Gunnes and Gjedrem, 1976), thus selection for less variation in body weight would advantageous to the producer. However, selection for increased body weight is associated with both advantageous traits (increased survival, increased fry survival, increased fecundity, and disease resistance) and disadvantageous traits such as decreased bacterial resistance (Dunham et al., 2000; Dunham and Smitherman, 1983; Smitherman and Dunham, 1985). Molony et al. (2004) reported that selection for growth also selected fishes for heat tolerance. Thus, the ability to select and develop strains that maximize positive traits and minimize negative traits would be of great advantage to the fish producer.

Allendorf and et al. (1987) reported that heritability of economically important traits such as length and weight is much lower in fishes as compared to other vertebrates. It was suggested that environmental factors play the largest role in a fish's phenotype, likely due to a combination of high phenotypic variability and low heritabilities (Allendorf et al., 1987; Fishback et al., 2002). This observation was supported by previous work in which the performance of specific crosses of rainbow trout was decreased in poorer environments, regardless of genetic capability (Klupp et al., 1978). In addition, several studies in rainbow trout have reported low heritabilities with values ranging from 0.06 to 0.30 (Gall, 1975, and as reviewed by Gjedrem, 1976). As such, maintenance of the proper environment, in addition to efforts to improve genetic stocks, is crucial to successful production. 
It is possible that heritabilities might be underestimated in fishes, as most studies evaluate mixed families. For example, examination of factors such as weight, length, and carcass yield showed differing heritabilities between two groups in which maternal effects were either minimized or maximized (Chevassus, 2002). Response to selection for growth rate in Salmonids ranges from 10 to $14 \%$ gain per generation, with rainbow trout gaining 10 to $13 \%$ per generation (as reviewed by Dunham et al., 2000 and Fjalestad et al., 2003). More recent evidence showed that the heritability of body mass and condition factor in rainbow trout was greater than 0.50 (Martyniuk et al., 2003).

Initial differences in phenotype are required for selection, and genetic differences between strains of rainbow trout have been reported for many traits. One study reported significant differences in both dry matter and lipid content, both of which affect product quality; differences in protein content were not significant (Ayles et al., 1979). Although initial differences were present in one year old 300g fish from related families, variation in body weight and length at commercial size (900 g) was not significant (Bonnet et al., 1999).

\section{Negative effects of inbreeding}

In aquacultured strains of rainbow trout, the degree of inbreeding is due to previous inbreeding, selection, and population size (Hynes et al., 1981; Ferguson and Danzmann, 1998). It is important to note that several hatchery stocks were developed from a limited number of founding broodstock (Kendall, 1920). For example, Dollar and Katz (1964) report that the Hot Creek Strain of rainbow trout was developed from four "superior" female trout. Hershberger et al. (1992) stated 
that "genetically sound approaches to management, conservation and hatchery strain development are dependent on the amount of variation in local reproducing units." Allendorf (1975) reported that from evaluation of 32 loci, average heterozygosity was lower in two hatchery strains (0.024 in West Virginia, and 0.020 in University of Washington) as compared to naturalized anadromous populations $(0.039-0.081)$. However, analysis of 24 loci in four hatchery strains in California did not support this observation, although strains with the simplest pedigrees had the least variation (Busack et al., 1979). Several others have discussed the loss of genetic variability in hatchery strains due to inbreeding (Allendorf and Phelps, 1980; Stähl, 1983). Thus, the closed populations present in hatchery strains can affect genetic variability of the stock (Hershberger, 1992.).

Such inbreeding can lead to inbreeding depression, which is the loss of advantageous traits due to mating among related individuals (Ferguson and Danzmann, 1998; Lynch 1995). Inbreeding can also result in the appearance of deleterious traits, such as abnormal body curvature, egg mortality, and mortality of rainbow trout fry (Aulstad and Kittelsen, 1971). Several studies have reported that heterozygosity has a positive effect on desirable traits (rate of development, egg size, developmental stability, growth and survival) (Danzmann et al., 1986; Danzmann et al., 1989; Ferguson and Drahushchak, 1990; Herbinger et al., 1995). This is of particular concern in aquaculture and government-maintained hatcheries, as managers do not commonly introduce unrelated individuals into their breeding programs. In addition, the majority of offspring from a spawning season could arise from a single mating, as many aquacultured species have high 
fecundity (McDonald et al., 2004). This is also likely in the hatchery setting in which gametes are commonly collected and pooled for fertilization, as it has been shown that the contribution of each individual parent is not equal in pooled gamete matings (Gharrett and Shirley, 1985; Withler, 1988; Gile and Ferguson, 1990). In combination, these factors could result in the decline of genetic variation in captive stocks. However, proper hatchery management can produce genetic variability similar to that of naturalized trout (Hynes et al., 1981;

Allendorf and Ryman, 1987; Ferguson et al., 1991; Hershberger, 1992).

Although it was suggested that a loss of genetic variability (Krueger and May (1987) and outbreeding depression, which is the loss of advantageous traits due to introduction of new alleles, can occur following introduction of individuals from other populations (Lynch 1995), Rieseberg et al. (1996) found that introduction of "foreign" genes may interact favorably when producing sunflower hybrids, resulting in increased fitness. From an aquaculture viewpoint, it is interesting that introduction of new alleles into a cultured population might enhance performance in rainbow trout, as suggested by Danzmann et al. (1999).

\section{Initial genetic analyses of salmonids}

Compared to other species, rainbow trout have a high degree of genetic variation (Ferguson and Danzmann, 1998). In rainbow trout, the diploid chromosome number is 60 , however, the number can vary from 58 to 64 (Thorgaard, 1977; Thorgaard, 1983a). In addition, sex chromosomes are absent in some individuals (Thorgaard, 1983a), and natural triploids have been identified (Thorgaard and Gall, 1979). Gene duplication in Salmonids has been well 
documented (Massaro and Markert, 1968; Bailey et al., 1970; Engel et al., 1970; Wolf et al.., 1970; Altukhov et al.,1972; Utter and Hodgins, 1972; Davisson et al., 1972), and this was possibly due to tetraploidy (Ohno et al., 1969). Other reports have provided data to support tetraploid inheritance in rainbow trout (Kingsbury and Masters, 1972). However, Morrison (1970) showed that 30 loci were not inherited in a tetrasomic manner. Allendorf and Utter (1973) suggested that tetrasomic inheritance might exist in some populations, whereas the same loci may be inherited in a disomic fashion in others; the authors stated that further study is necessary to verify this possibility. It was also stated that studies supporting the idea of tetraploid inheritance often confuse allele polymorphism with that of gene duplication. Also, it was reported that gene duplication occurs at some loci, but not all, although polymorphisms were present at all loci examined (Utter and Hodgins, 1972). More recently, McKay stated that further divergence of the chromosomes resulted in a return to disomic inheritance (McKay et al., 2004). Thus, evaluation of new loci could show either disomic or tetrasomic inheritance.

\section{Common methods of genetic identification}

Although the variability of specific proteins has been shown in many studies, overall, heterozygosity in protein-coding loci is low (Ferguson et al., 1995). Also, examination of protein-coding loci is not suitable in all species. For example, Arctic char (Salvelinus alpinus) have a very low level of heterozygosity at protein-coding loci, which limited genetic studies using these methods (Ferguson et al., 1995). Current methods allow the determination of genetic variation by 
examination of several additional types of "molecular markers." Bagley et al. (2002) defined molecular markers as "an easily discerned measure of the genotype of an individual at a locus based on molecular biological methods... usually based on attributes of DNA, but may be based on RNA or protein." Thus genetic variation may be determined by using one or a combination of several different molecular biological tools: examination of allozymes, amplified fragment length polymorphisms (AFLP), denaturing gradient gel electrophoresis (DGGE), mitochondrial DNA sequences, random amplified polymorphic DNA (RAPD), restriction fragment length polymorphisms (RFLP), single-copy nuclear DNA (scnDNA), single-strand conformation polymorphism (SSCP), and simple sequence repeats (SSR). All of these techniques have been employed to examine genetic differences in Salmonids (Table 3; Ferguson and Danzmann, 1998).

\section{Advantages to DNA-based methodologies}

Bagley and et al. (2002) provided an excellent review of the advantages of DNA-based methods of genetic identification, including such factors as the ability to measure genetic diversity without the interference of cellular processes such as transcription, splicing, translation, and post-translational processing. Ferguson et al. (1995) listed several additional benefits of the use of DNA:

- Only a single tissue is needed in DNA analysis. In protein electrophoresis, several tissues must be sampled.

- Tissues may be preserved in alcohol or may be dried, thus historicallycollected scale samples can provide genetic information of Salmonids over the last 100 years. Samples for protein analysis must be obtained from fresh or frozen tissues. 
- Limited sample volumes are required, especially when using PCR-based methods, requiring only small biopsies. In addition, embryos provide sufficient sample to provide genetic information.

- Adipose fin biopsy samples can be quickly taken. Sampled individuals can then be released without harm.

In addition, the non-lethal use of fin biopsies or scales for DNA analysis, as compared to protein-based methods is desirable when working with endangered species or populations (Nielsen et al., 1999).

Mitochondrial DNA (mtDNA) and a variety of DNA regions containing variable number of tandem repeats (VNTRs, includes satellite, minisatellite, and microsatellite DNA) (Epplen, 1992, 1994) have been used in many studies. Mitochondrial DNA is unique in that it is inherited solely maternally and lacks recombination, thus allowing determination of matriarchal lines (Ferguson et al., 1995). Many studies have examined mtDNA via restriction digestion, sequencing, and PCR of specific loci (Table 3), however, Ferguson and Danzmann (1998) determined that sequencing of mtDNA did not provide additional information beyond that of restriction digestion. Mitochondrial DNA and VNTRs have a much higher mutation rate as compared to protein-coding loci, which increases the ability to distinguish populations and individuals (Ferguson et al., 1995), and it has been shown that VNTRs are the most polymorphic (Prodohl et al., 1992).

The first reports to link differences in satellite DNA to differences in phenotype found that lesser amounts of a GATA repeat were present in female versus male Elaphe radiate, the copperhead ratsnake (Singh et al., 1976; Epplen et al., 1982). Subsequently, DNA "fingerprinting" using minisatellites (greater 
than 6 bases per repeat) became available (Jeffreys et al., 1985). Evaluation of minisatellite DNA has been performed in several Salmonid species (Beacham et al., 1996; Miller et al., 1996; Taggart et al., 1995; Galvin et al., 1996; Table 3).

Microsatellites are molecular "markers" composed of short, tandem repeats of 2-6 base pairs located in non-coding regions of DNA. Due to variability in the number of the tandem repeats, microsatellites are highly polymorphic, and thus, informational. In addition, microsatellites are codominant, and are easily analyzed using PCR and automated DNA sequencing technologies. Although minisatellite DNA is more highly polymorphic than microsatellite DNA (Chakraborty \& Jin, 1993; Edwards et al., 1992; Budowle et al., 1991; Odelberg et al., 1989), unlike minisatellites, microsatellites are easy to identify and have a size-range appropriate for use with PCR-based technologies (Blouin et al., 1996; Dietrich et al., 1992; Weissenbach et al., 1992).

The use of microsatellites is fast, simple, detailed, and cost-effective as compared to other methods (Bagley et al. 2002). In a direct comparison study of allozyme and microsatellite data from brown trout, Estoup and et al. (1998b) found that microsatellites provided better resolution as compared to allozyme data. Likewise, examination of genetic diversity in brown trout via analysis of microsatellites revealed greater genetic diversity than that obtained by allozyme analysis (Corujo et al., 2004; Colihueque et al., 2003). As such, the authors suggested that use of microsatellites is preferred to that of allozyme analysis, which is supported by the observation that microsatellite sequences exhibit a much greater rate of mutation as compared to allozymes (Estoup et al., 1998b). In 
rainbow trout, studies have found the greatest amount of genetic differentiation when using microsatellite analysis of six loci as compared to RFLP of mtDNA and allozyme analysis (Ferguson and Danzmann, 1998; O’Connell et al., 1997). In addition, a recent study examined microsatellites developed from expressed sequence tag (EST) libraries, which provided greater success in cross-species amplification and provided greater polymorphism information content (Coulibaly et al., 2005).

Although initial development cost is high and technical expertise required is greater compared to other methods, once developed, analysis of microsatellites can provide needed information on genetic variation. Additional advantages and disadvantages were discussed by Ferguson and et al. (1995); the authors stated that little comparative information from DNA-based studies is available, however, since that time, microsatellite analyses have been rapidly applied to a variety of fish species.

Smouse and Chevillion (1998) provided insight into proper microsatellite loci selection, including such factors as number of loci, number of alleles, and size range of alleles. For best results, the authors suggested that a "modest number of independently segregating, multiallelic, codominant loci, each locus with a small number of alleles, with each allele in moderate frequency." However, it was discussed that although selection of "best" loci based on loci characteristics is possible, there are few practical examples (Beacham et al., 2002). Cornuet and et al. (1999) suggested scoring 10 loci of 30-50 individuals from 10 populations using Bayesian classification. Studies in Salmonids have used as few as six loci 
(Beacham and Wood, 1999; Beacham et al., 2000a, 2000b; Withler et al, 2000). Analysis of many microsatellite loci with few possible alleles and analysis of a few loci with many possible alleles provides equivalent results (Kalinowski, 2002). Likewise, it was determined that the use of highly polymorphic loci (with expected heterozygosities greater than 0.62 ) reduces the number of loci required without sacrificing accurate results (Blouin et al., 1996).

Bernatchez and Duchesne (2000) developed a model to determine the additive contribution of the number of loci and number of alleles; loci with more than six to ten alleles did not provide any additional advantage in assigning individuals to their source population. In contrast, when identification of individual sockeye salmon was achieved using 14 loci, loci with greater numbers of possible alleles improved identification of the population source of individuals, regardless of the $\mathrm{F}_{\text {ST }}$ values of the loci (Beacham et al., 2002). This observation has been supported by additional studies (Beacham et al., 2003; Beacham et al., 2001; Cornuet et al., 1999). In addition, $80 \%$ of individuals were correctly identified with four loci, and 10 additional loci increased successful identification to $90 \%$ (Beacham et al., 2002).

Previous studies have shown that the majority of the total genetic variation in rainbow trout exists within, rather than among, populations (Allendorf and Phelps, 1981; Ryman, 1983; Hershberger 1992). Because microsatellite analysis provides a more detailed examination of genetic variation as compared with other methods, use of microsatellite markers should be the preferred choice to detect variation between populations or strains. In addition, unlike other available 
methods, microsatellites can distinguish closely related individuals by examination of frequencies of shared alleles (Ferguson and Danzmann, 1998). However, microsatellite analysis was reported to underestimate genetic differentiation (Balloux et al., 2000).

Ideally, markers used for population studies should have a verified inheritance and linkage patterns and demonstrate stable germ-line transmission (Ferguson et al., 1995), however, most studies do not provide this information. Verification of such aspects of microsatellite markers is of particular importance in Salmonids, as many protein-coding loci demonstrate abnormal segregation, likely due to the tetraploid nature of the genome (Wright et al., 1983). Although microsatellites are reported to be highly conserved within a species in mammals (Moore et al., 1991), a detailed examination of the dinucleotide microsatellite locus SFO-12 among 12 Salmonid species showed that detectible differences in loci can be due to factors other than differences in repeat number (Angers and Bernatchez, 1997). The authors suggested that caution should be used when only repeat number is used to determine genetic differences, especially when comparing different Salmonid species.

Thus, due to their informational content and ease of use, evaluation of microsatellites has become the preferred method of genome investigation (Epplen et al., 1998), and numerous analyses have been performed in many species, including the rainbow trout. In fishes, studies have been useful in determining parentage, relatedness, development of genetic maps, and detection of loci linked to traits of economic importance (QTLs). In addition, microsatellites have been 
used extensively for comparison of hatchery, wild, and naturalized stocks (Table $3)$.

\section{Microsatellites aid identification of quantitative trait loci}

In 1949, Alm reported production differences between strains of brown trout originally collected from either stream or lake. As early as 1975, Ayles reported that genotype-environment interactions affected growth and survival rates. To determine suitability of different strains for aquaculture, Ayles examined fish from specific matings of both wild and domesticated strains of rainbow trout, and reported that growth and survival were significantly affected by genotypeenvironment interactions. Today, with the use of microsatellites, researchers can more easily quantify the effects of multiple genes and genotype-environment interactions on traits of economic importance, as these markers have an additional advantage in that some sequences have been "linked" to genes of interest. As a molecular "marker," these repeat sequences may be in close proximity to specific genes, such as genes that have been identified or associated with desirable production traits (Lande and Thompson, 1989), thus examination of the genetic basis of an individual's variation in performance is possible (Ferguson and Danzmann, 1998). Succinctly described as "the basis of adaptation and economic productivity" (Ferguson and Danzmann, 1998), these markers can be employed in the identification of specific, desirable alleles that are most often referred to as quantitative trait loci (QTL).

Examination of QTLs would be advantageous in aquaculture, as many desirable traits are quantitative, and examination of single genes or groups of 
genes is not of great benefit in broodstock development (Hershberger, 1992).

Evaluation of QTLs can aid identification of populations, strains, or individuals that express desirable alleles, and subsequent marker assisted selection (MAS) can be used to develop strains better suited for culture in that mating decisions are based on genotype (Ferguson and Danzmann et al., 1998). For example, QTLs affecting upper temperature tolerance, time of spawning, growth, feed efficiency, bacterial disease tolerance, embryonic developmental rates, and cold tolerance, infectious hematopoietic necrosis susceptibility, and the MHC class II beta-chain intron (Table 3) have been identified in rainbow trout.

\section{Continued use of other marker types}

The continued increase in the number of available microsatellite markers, coupled with increased automation resulting in increased ease of use, has led many researchers to abandon previously available techniques. However, not all marker types suit all types of genetic analyses, and the proper type of genetic marker should be carefully chosen. For example, Ferguson and Danzmann (1998) reviewed methods to aid choice of proper markers and examined the effectiveness of mtDNA, RAPD, and hypervariable nuclear loci (including minisatellites and microsatellites). The authors concluded that, "Examples illustrate that no one marker type is appropriate for all applications. Choice should be based on the evolutionary genetic attributes of both the species and the marker loci themselves." The focus of the current study is the use of microsatellites, however, other studies might be better served by "older" types analyses, including examination of allozymes and other regions of DNA. Regardless of type of 
analyses, "the detection of polymorphism remains the key," and the best method to ensure proper marker selection is to test a variety of marker types within the same geographic area (Ferguson and Danzmann, 1998).

The overwhelming majority of studies have been performed on wild stocks and hatchery-developed stocks for enhancement of wild stocks. Because of increasing demand for aquacultured products, the wealth of knowledge gained from the study of wild Salmonids (genetic variability, genetic divergence, stock structure, response to selective breeding, growth responses, and response to a variety of culture-induced challenges) should enhance development of superior stocks for aquaculture use.

\section{USE OF MICROSATELLITES FOR STRAIN IDENTIFICATION OF RAINBOW TROUT}

The development and application of genetic markers to the study of Salmonids, both in hatchery stocks and wild populations, has been extensive. The three primary areas of study have been stock structure analysis of native and naturalized (wild) populations, taxonomic analyses, and development and evaluation of strains suitable for aquaculture and release for maintenance of wild stocks (Ferguson and Danzmann, 1998). Ferguson et al., (1995) expanded this list to include studies of both natural populations and cultured stocks, including applications such as:

- Species and hybrid identification

- Establishing species and population phylogeny and phylogeographic history

- Determination of population (stock) structure

- Identification of proprietary strains 
- Individual stock contribution to mixed stock fisheries

- Measuring level of, and changes in, genetic variation in wild and cultured populations

- Estimation of effective population size

- Identification of key populations for conservation

- Locating source material for supplementation and restoration

- Assessing performance of stocked fish

- Determining genetic impact of deliberate and inadvertent introductions of cultured fish on natural populations

- Establishing gender of individuals

- Determination of breeding strategies

- Comparing relative fitness of life history variants (survival of offspring relative to parental parameters)

- Elimination of "tank effect" in breeding experiments

- Gene mapping

- Quantitative trait linkage analysis

- Assessing success of genomic manipulations

Prior to the availability of DNA sequence information, identification of protein variants (allozymes) via electrophoresis was the principle method of genetic analysis in Salmonids (Utter et al., 1987). This method allowed researchers to quickly and accurately determine population structure and existing genetic variation in wild and hatchery stocks throughout the world (Table 3).

Coupled with the rapid decline in wild populations, it was suggested that surveys of populations using protein electrophoresis should be quickly performed (Ferguson and Fleming, 1983). Although protein electrophoresis was used to distinguish differences in a gene's allele, Allendorf (1977) stated that factors such as sample handling, tissue of origin, and physiological differences can all cause changes in a protein's "electrophoretic phenotype." Although this was a matter of debate at that time, the majority of protein variants were verified as distinct alleles by genetic experimentation (Allendorf, 1977) 
Studies have analyzed hemoglobin, transferrin, and a variety of enzymatic proteins (Ferguson et al., 1995). In one study, analysis of 38 populations of rainbow trout suggested that genetic variation among natural populations was similar (Allendorf, 1975). However, in European brown trout (Salmo trutta), regardless of absence of geographic separation, distinct populations have been identified within a single water body (Ryman, 1995; Ryman et al., 1979; Ferguson and Mason, 1981; Crozier and Ferguson, 1986; Krieg and Guyomard, 1985), and "proximate populations" of steelhead (anadromous rainbow trout) demonstrate genetic differences (Parkinson, 1984). Thus, some studies support the observation that populations within a single water body may be composed of separate, reproductive isolated populations. Overall, studies using protein electrophoresis have demonstrated that species of Salmonids can be divided into genetically distinct groups (Ferguson et al., 1995).

In comparison of wild and hatchery stocks of brown trout, Krueger and May (1987) evaluated polymorphic enzyme expression, and found that wild stocks were less genetically diverse compared to hatchery stocks. The authors suggested that distinct populations form unique gene pools, lead to genetic divergence, and increase overall genetic variability. Similarly, in rainbow trout, introduction and subsequent adaptation of naturalized populations could lead to genetic divergence. Thus, introducing individuals from other populations should be carefully considered, as this could lead to changes in genetic diversity of the species (Krueger and May, 1987; Allendorf and Leary, 1988; Allendorf, 1988). As a means to preserve the existing genetic structure of a population, it was 
suggested that wild-collected gametes should be utilized to produce fish for stocking, as those fish would be most genetically fit for the environment. Thus, the use of genetic information would aid the identification of distinct populations, and proper management, including stocking and angling regulations could be made separately for each population (Krueger and May, 1987).

\section{Identification and maintenance of wild, naturalized, and hatchery stocks}

According to several state and federal hatchery managers (pers. comm.), many "strains" of rainbow trout listed with the National Fish Strain Registry for trout (Kincaid et al., 2002) have been developed from hybridizing existing native and hatchery-developed strains under differing environmental conditions. Some hatchery managers believe that the selective breeding necessary in small, closed hatchery populations may have resulted in decreases in reproductive performance or increases in numbers of abnormal fish. Thus, identification of closely related strains with similar spawning and growth characteristics for out-crossing to improve heterosis, without loss of key characteristics such as time to maturity, size, and time of spawning, is desired.

The degree of population diversity is of primary importance in management of wild and naturalized stocks. Banks (2000) suggested that genetic identification is needed to identify (1) protected stocks in mixed ocean harvests, (2) protected stocks in dammed or water-diverted rivers and estuaries, and (3) broodstock for propagation to avoid hybridization of genetically distinct spawning populations. In addition, identification of the degree of genetic diversity is a useful tool to 
evaluate environmental conditions ( ${ }^{1}$ Bagley et al, 2002), and to identify the presence of evolutionary significant units (ESUs, Waples, 1991), which are the most frequently encountered problem in fisheries management (Ryman and Utter, 1987).

In many instances, re-introduction of hatchery-raised fishes has been necessary to maintain threatened and endangered stocks (Ferguson et al., 1991). For successful maintenance of such stocks, release programs must maintain a level of genetic variability in hatchery stocks comparable to diversity in the wild stocks and must also minimize adaptation of the fishes to a hatchery, rather than wild, environment (Ferguson et al., 1991; Meffe, 1986). Loss of genetic variability in hatchery stocks has been well documented (Allendorf, 1975; Allendorf and Phelps, 1980; Vuorinen, 1982; Cross and King, 1983; Stahl, 1983; Gyllensten and Wilson, 1987; Verspoor, 1988; Ferguson et al., 1991; Hershberger, 1992). Therefore, managers must be able select broodstock to minimize inbreeding (Blouin et al., 1996; Hedrick \& Miller, 1992; Lacey 1989).

The use of molecular techniques to successfully identify genetic diversity can minimize such problems. For example, to avoid improper hybridization of distinct stocks of chinook salmon, selection of broodstock is currently aided by microsatellite analysis (Banks, 2000). Some studies have used morphological/phenotypic traits to estimate genetic diversity in wild stocks (Aparicio et al., 2005). Many such traits are altered by gene interaction and environmental influences, and the use of molecular markers provides an

\footnotetext{
${ }^{1}$ One such study evaluated the environmental impact in coal mined areas on the genetic diversity of creek chub (Semotilus atromaculatus) in WV and western PA using AFLP and sequencing of mitochondrial DNA sequences.
} 
alternative that eliminates such influences (Bagley et al., 2002). In addition, as previously discussed, evaluation of protein and chromosome data presents conflicting explanations of rainbow trout population structure; evaluation of DNA sequences can clarify this discrepancy. In addition, an identity panel of microsatellites capable of distinguishing strains of rainbow trout could be used to determine if poaching and illegal importation has taken place, as demonstrated in cases involving white-tailed deer, moose, and black bear (Guglich et al., 1993; Guglich et al., 1994).

\section{Identification of food products}

Value-added products, such as smoked fish, are produced from a variety of fish species. To prevent mislabeling and misrepresentation of such products, identification of contents can be achieved through the use of specific molecular biology techniques. Researchers have commonly identified fish products by protein analysis, however, molecular biology techniques that utilize DNA can be performed on cooked products in which the representative proteins have been denatured (Carrera et al., 1999a). Smoked Atlantic salmon, rainbow trout, and sea bream can be distinguished by polymerase chain reaction (PCR) amplification of the 5S rDNA nuclear marker (Carrera et al., 2000a). Raw and smoked Atlantic salmon and rainbow trout can be distinguished by PCR-RFLP of the p53 gene (Carrera et al., 2000b), mitochondrial cytochrome oxidase gene (Carrera et al., 1999a), mitochondrial 16S rRNA gene (Carrera et al., 1999b), and mitochondrial cytochrome b gene (Carrera et al., 1998). However, as more specific methods for genetic testing are currently available, development of techniques to distinguish 
strains of rainbow trout would be of great benefit in preventing poaching and illegal importation.

\section{Identification of rainbow trout strains}

As previously discussed, ease of culture and transport (MacCrimmon 1971), adaptability to a variety of environments (Ryman, 1983; Hershberger, 1992), and popularity with both anglers and consumers, has encouraged the development of rainbow trout culture. Many strains of rainbow trout with a variety of performance traits are available (National Fish Strain Registry, Kincaid, 2002). It was suggested that the variety of culture backgrounds in differing strains would lead to detectable differences between strains (Ferguson, 1994).

\section{Use of F statistics in population studies}

In describing genetic differences within groupings (e.g. species and populations), F statistics are the most commonly used. F statistics are a further examination of observed and expected frequencies of heterozygotes at a locus (Avise, 1993). An extension of the inbreeding coefficient, F, proposed by Wright (1922), F statistic values can be used to describe population structure. FST values are a measure of population structure; an FST of zero indicates no population structure whereas an FST equal to one indicates that the population is completely differentiated (McDonald, 2004), and they also represent variance in allele frequencies among populations (Avise, 1993). Pairwise FST values allow comparison of the degree of differentiation between population pairs. FIS values are a measure of the degree of inbreeding within a population; FIS 
equal to one indicates complete inbreeding (McDonald, 2004). FIS values are a measure of the "correlation between homologous alleles within individuals with reference to the local population" (Avise, 1993). FIT values are a measure of the "corresponding allelic correlation with reference to the total population" (Avise, 1993), and is a measure of "total inbreeding averaged across all loci" (Silverstein et al., 2004). Positive values for FIS and FIT indicate the loss of heterozygosity, likely due to local inbreeding (FIS), or local inbreeding plus population subdivision (FIT, Avise, 1993).

\section{OBJECTIVE}

As an important farmed species, genetic identification and analysis of rainbow trout is necessary to (1) be able to easily distinguish rainbow trout in fish products, (2) identify truly unique strains, and (3) utilize marker-assisted selection to develop superior strains of trout for commercial production and to support stocking efforts. The purpose of this study was to develop and utilize polymorphic microsatellites to examine variation among rainbow trout strains and develop a preliminary identification panel of microsatellite markers capable of distinguishing individual U.S. trout strains listed with the National Fish Strain Registry.

\section{MATERIALS AND METHODS}

Two microsatellite-enriched libraries (ATG and TAGA base-pair repeats) were purchased from Genetic Identification Services (Chatsworth, CA). Methods for their construction were similar to those described by Ausubel and et al. (1992) 
and Cheng and Crittenden (1994). Libraries were stored at $-80^{\circ} \mathrm{C}$ as glycerol stocks of the bacterial cells.

A small scraping of each library was removed and recovered by incubation at $37^{\circ} \mathrm{C}$ for $1 \mathrm{hr}$. Cells $(100 \mu \mathrm{l}$ of cell mixture) were then plated onto Luria-Bertani (LB) agar plates containing ampicillin $(100 \mu \mathrm{g} / \mathrm{ml})$, Isopropyl $\beta$-D-1thiogalactopyranoside (IPTG, $0.5 \mathrm{mM}$ ), and x-gal (5-bromo-4-chloro-3-indolyl-bD-galactoside; $40 \mu \mathrm{g} / \mathrm{ml}$ ) and incubated overnight at $37^{\circ} \mathrm{C}$. Individual colonies were selected and cultured in liquid Luria-Bertani culture medium containing ampicillin (VWR Scientific, West Chester, PA) for plasmid preparation.

Double-stranded plasmid DNA templates were prepared from each clone by use of Qiagen Spin Mini-prep Columns using prepared buffers (Qiagen, Valencia, CA, buffer P1: $50 \mathrm{mM}$ glucose, $25 \mathrm{mM}$ Tris- $\mathrm{HCl}$ at $\mathrm{pH}$ 8.0, $10 \mathrm{mM}$ EDTA at $\mathrm{pH}$ 8.0, $100 \mu \mathrm{g} / \mathrm{ml}$ RNase A; buffer P2: $0.2 \mathrm{~N} \mathrm{NaOH}, 1 \%$ SDS; buffer N3: $3 \mathrm{M}$ KOAc at pH 4.8; buffer PB: $3 \mathrm{M}$ guanidine-HCl; buffer PE: $10 \mathrm{mM}$ Tris- $\mathrm{HCl}$ at $\mathrm{pH} 7.0,50 \%$ EtOH; buffer EB: $10 \mathrm{mM}$ Tris-HCl, $\mathrm{pH} 8.5)$. The sequence of the 5' end of each plasmid was examined by single-pass sequencing using M13 universal primers. The Sanger dideoxy termination method (Sanger et al., 1977) and BigDye Terminators (Perkin Elmer, Foster City, CA) were used to sequence 1 $\mu \mathrm{l}$ (approximately 200-500 ng) of the prepared plasmid DNA. Sequencing products were analyzed with an ABI Prism 310 automatic DNA sequencer (Perkin Elmer, Foster City, CA).

To select unique PCR primers for amplification across each microsatellite, data from microsatellite markers that contained adequate single-copy flanking 
sequences to generate usable primers for subsequent amplification of the repeat region were analyzed with Gene Tools 1.0 software (Edmonton, Alberta, Canada). Synthetic primers were obtained from Alpha DNA (Montreal, Quebec, Canada); primers were labeled with FAM, HEX, or NED fluorescent dyes for use in fragment analysis.

Genomic DNA was isolated with an AquaPure Genomic DNA Kit (BioRad, Hercules, CA), according to manufacturer's protocol, from fin tissue of Kamloops, Arlee, Hot Creek, Swanson, Oregon State University (provided by USDA National Center for Cool and Coldwater Aquaculture, Leetown, WV), and Wytheville strains (collected from Petersburg State Fish Hatchery, Petersburg, WV) of rainbow trout. Polymerase chain reaction (PCR) was performed by adding $1 \mu \mathrm{l}$ of the isolated genomic DNA to a tube containing $49 \mu$ of PCR master mix containing $41 \mu 1$ nuclease free water, $5 \mu 1$ Taq buffer, $1 \mu 1$ Taq DNA polymerase, $1 \mu 1$ of a dNTP mixture (final concentration of $1 \mathrm{mM}$ each $\mathrm{dNTP}$ ), $0.5 \mu \mathrm{l}$ each of microsatellite-specific forward and reverse primers (50 $\mu \mathrm{M}$ final concentration of each primer). Proper annealing temperatures for each set of primer pairs were determined by an initial PCR using an annealing temperature gradient from $55^{\circ} \mathrm{C}$ to $70^{\circ} \mathrm{C}$. The resulting PCR products were electrophoresed on an ethidium bromide-stained $2 \%$ agarose gel and visualized using a FluorChem 8000 Imager (Alpha Innotech Corp., San Leandro, CA). Products that showed a single band that could be clearly resolved were sized, and polymorphism was determined by variations in the size of amplified microsatellite region. 
Polymorphic markers that amplified a 100-300 bp fragment were further analyzed using Gene Scan (Applied Biosystems, Chatsworth, CA). Twenty-one markers were chosen for further analysis based on predicted product length that provided the possibility of multiplexing (pooling with other labeled primers with differing fluorescent labels) in future studies; thirteen markers that showed disomic inheritance patterns based on Gene Scan output were used in panel development and determination of genetic variation.

One hundred and sixty fin-tissue sampling kits containing 10 individual tissue-biopsy punches (Salvin Dental Specialties, Charlotte, NC), plastic tubes, and $70 \%$ ethanol were shipped to each location maintaining rainbow trout broodstocks listed in the National Fish Strain Registry for Trout (Kincaid, 2002). Fin punches of 10 individual fish from 55 strains were obtained; DNA was isolated as previously described. Ten strains [Arlee, Big Spring, Colorado River, Eagle Lake, Ennis, Erwin, Kamloops (Lake Superior), Kamloops (Trout Lodge MD), Shasta, and Wytheville (Table 4)], were selected for genetic analysis because of frequent use as broodstock in developing other strains (Kincaid, 2002).

Polymerase chain reaction and gel electrophoresis were performed using fluorescent labeling methods as described by Ashwell and et al. (1998). Approximately $50 \mathrm{ng}$ of genomic DNA were amplified in the presence of $1.5 \mathrm{mM}$ $\mathrm{MgCl}_{2}, 50 \mathrm{mM} \mathrm{KCl}, 10 \mathrm{mM}$ Tris. $\mathrm{HCl}(\mathrm{pH}$ 9.0), $10 \mu \mathrm{M}$ each of dCTP, dGTP, dTTP, and dATP, $0.4 \mu \mathrm{M}$ of a fluorescently tagged forward primer, and $0.4 \mu \mathrm{M}$ of an unlabeled reverse primer, and 0.35 units of Taq DNA polymerase in a total volume of $50 \mu \mathrm{L}$. The MJ Research DNA Engine (Watertown, MA) thermal 
cycler protocol was as follows: $94^{\circ} \mathrm{C}$ for $3 \mathrm{~min}$, followed by 40 cycles of $1 \mathrm{~min}$ at $94^{\circ} \mathrm{C}, 1 \mathrm{~min}$ at the annealing temperature (Table 5), $1 \mathrm{~min}$ at $72^{\circ} \mathrm{C}$, and a final extension period of $5 \mathrm{~min}$ at $72^{\circ} \mathrm{C}$.

Size-scoring and analysis of the amplification products were performed using Gene Scan Analysis on an ABI Prism 310 automated DNA sequencer (Applied Biosystems, Foster City, CA). Each of the products was diluted 1:20 with nuclease-free water (Promega, Madison, WI); one $\mu \mathrm{l}$ of the resulting dilution was combined with $0.5 \mu \mathrm{l}$ of ROX 350 internal standard (Applied Biosystems, Foster City, CA) and $12 \mu \mathrm{L}$ deionized formamide, and subsequently mixed, denatured by heating to $94^{\circ} \mathrm{C}$ for $1 \mathrm{~min}$, and loaded onto the sequencer using manufacturer's standard instrumentation protocols.

Samples failing to produced readable genotypes (unstable baseline, high or low peak amplitude, absence of amplification, appearance of more than two peaks) were subjected to a second series of PCR and Gene Scan analysis.

\section{$\underline{\text { Statistical Analyses }}$}

Assignment of individuals to strain of origin was performed with GeneClass (version 1.0.02). Percent of loci that have multiple alleles (percent loci variable), number of heterozygous individuals, $\mathrm{F}$ statistics, and genetic distances were calculated using Biosys-1 (version 1.7). Between-population heterogeneity tests and pairwise Fst values were calculated using GenePop (version 3.4). Genetic distance was determined by chord distance as in Cavalli-Sforza and Edwards (1967). 


\section{RESULTS}

Three hundred and eighty-four clones from the TAGA-repeat library and 192 clones from the ATG-repeat library were sequenced and examined for the presence of microsatellite repeat sequences, for a total of 576 clones sequenced. Forty-eight percent contained microsatellites, and 58\% of the microsatellitecontaining sequences contained adequate non-repeating flanking regions for possible primer design. Primers were successfully designed for 56 markers (Table 5), and sample information was submitted to National Center for Biotechnology Information (NCBI) GenBank database for all markers that produced PCR products. The initial PCR reaction performed to identify polymorphic markers performed with DNA from one individual each representing Kamloops, Arlee, Hot Creek, Swanson, Oregon State University, and Wytheville strains of rainbow trout was successful for 40 primer pairs, and 37 loci were polymorphic.

Participation by fish hatchery managers (sample collection, providing specific broodstock histories and characteristics) was positive, with a $31 \%$ return rate of the sample collection packets. The majority of managers who failed to participate provided information as to the status of the current strain. In all cases, the strain was no longer maintained at the listed location.

Genotyping was not possible for all twenty-one markers that were chosen for further analysis. Loci OMM1444, OMM1447, OMM1448, OMM1454, OMM1455, OMM1486, OMM1487, and OMM1494 did not produce useable 
Genotyper data, either due to poor amplification, non-repeatable results, or the appearance of amplification of two loci.

For each locus evaluated, allele identifiers for genotypes and length in basepairs are provided in Table 6 . Evaluation of 10 individuals each from ten selected strains (Table 4) produced unique genotypes for each individual (Table 7). The observed genetic diversity for each ranged from four alleles (marker OMM1462) to 24 alleles (marker OMM1483), with an average of 13.5 alleles per locus. The average number of alleles present in each strain ranged from 3.7 (Wytheville strain) to 6.5 (Kamloops Lake Superior) per locus. Each strain contained unique alleles (Table 7), and unique alleles were present for each marker with the exception of marker OMM1462. In addition, no PCR product was obtained for markers OMM1453 and OMM1462 in Ennis, markers OMM1462 and OMM1478 in Kamloops Lake Superior, and OMM1461 and OMM1451 in Wytheville strains. Percent of variable loci was 90.9\% in Wytheville, $92.3 \%$ in Shasta and Arlee, and 100\% in all other strains.

Number of alleles present in each strain, and average heterozygosity within and among strains are presented in Table 9. Mean observed heterozygosity for each strain ranged from $0.393 \pm 0.119$ for Wytheville to $0.724 \pm 0.071$ for Kamloops Lake Superior; for each strain heterozygosity was less than HardyWeinberg expected values (Table 9). Mean observed heterozygosity over all loci for all strains was 0.523 , with a mean Hardy-Weinberg expected value of 0.6717 . The greatest difference between expected and observed values was in Wytheville strain (0.26) as compared to a difference of 0.19 or less in all other strains. The 
observed number of heterozygotes for each locus within strains showed that 81 of $118(68.6 \%)$ were less than expected (Table 10). Between-population heterogeneity tests were significant for all pair-wise comparisons of strains ( $p$ $<0.00001)$.

F-statistics ( $\mathrm{F}_{\mathrm{IS}}, \mathrm{F}_{\mathrm{ST}}, \mathrm{F}_{\mathrm{IT}}$ values) are provided in Table 11. $\mathrm{F}_{\mathrm{IS}}$ values ranged from -0.0639 (locus A-32) to 1 (OMM1478); mean $\mathrm{F}_{\mathrm{IS}}$ was 0.2182 . $\mathrm{F}_{\mathrm{ST}}$ values ranged from 0.0927 (locus OMM1483) to 0.3640 (locus OMM1445); mean $\mathrm{F}_{\mathrm{ST}}$ was 0.1533 . $\mathrm{F}_{\text {IT }}$ values ranged from 0.0982 (locus OMM1459) to 1.0000 (locus OMM1478); mean $\mathrm{F}_{\text {IT }}$ was 0.338. Mean $\mathrm{F}_{\text {IS }}$ values was least in Big Spring (0.0651) and greatest in Wytheville (0.4628; Table 12).

Of the 100 fish surveyed, allele frequencies evaluated by GeneClass correctly assigned 92 individuals to their respective strain of origin. Individuals from Big Spring, Eagle Lake, and Shasta strains were all assigned to the correct strain of origin, two individuals from the Erwin strain were incorrectly assigned, and one misidentified fish was incorrectly assigned in the remaining strains (Table 13). Genetic differentiation between each pair of strains (pair-wise $\mathrm{F}_{\mathrm{ST}}$ values) was least in comparison of Kamloops-Trout Lodge and Erwin (0.0519) and greatest in comparison of Ennis and Arlee (0.2595; Table 14). Genetic distance between strains was least between Erwin and Ennis (0.43855) and greatest between Wytheville and Shasta $(0.73634$, Table 15, Figure 1).

\section{DISCUSSION}

Much genetic research concerned with native and naturalized wild fish populations has been performed (Table 3). Genetic analysis has been of benefit 
in determining population structure in wild and released hatchery populations of rainbow trout, thereby assisting in conservation and restoration decisions. This vast amount of genetic information available concerning native, naturalized, and hatchery-spawned and released Salmonids can be of great use to the aquaculturist. For example, performance of individuals is related to heterosis in that animals with increased heterozygosity out-perform homozygous individuals. In addition, genetic selection of superior individuals requires the identification and exploitation of genetic variation. Likewise, the importance of maintaining withinpopulation genetic variation has been emphasized (Hershberger, 1992). Thus, examination of existing genetic variation and the degree of heterozygosity present in existing strains of rainbow trout is of great importance in developing superior strains for aquaculture.

In the present study, examination of 576 clones from rainbow trout genomic DNA TAGA-repeat and ATG-repeat libraries resulted in identification of thirtyseven polymorphic microsatellite markers. Percentage of successful identification ( 37 of 576 clones sequenced; $6.4 \%$ ) is similar to data previously reported for these libraries (5.7\% Rexroad et al., 2002a). Positive response from hatchery managers demonstrates that samples can be collected in a rapid and cost-effective manner. In addition, as many strains listed in the National Strain Registry are no longer available, updating the registry with the obtained information would be of benefit.

No PCR product was obtained for markers within Ennis, Kamloops Lake Superior, and Wytheville strains. This is likely due to the presence of a null allele within the strains. Null alleles describe the occurrence of a polymorphism in the 
flanking regions to which the complementary base-pairing PCR primers have been designed (Dakin and Avise, 2004), thus failure of the PCR reaction occurs and genotyping individuals for the locus is not possible. Occurrence of null alleles can lead to inaccuracies in the calculated deviation from Hardy-Weinberg expected values (VanOosterhaut et al., 2006).

The presence of possible null alleles in rainbow trout microsatellite markers was discussed by Rodriguez et al. (2003) as a possible reason some primer pairs fail to amplify targeted sequences, and it was reported that as many as $16 \%$ of rainbow trout microsatellite loci may contain null alleles (Arden et al., 1999). A null allele was reported in a rainbow trout microsatellite by Holm and et al. (2001), and it was determined that failure of primer annealing was caused by a deletion of an $\mathrm{AC}$ repeat sequence within a primer recognition site. Thus, the authors suggest that repetitive sequences within primers be avoided. In the present study, primers for markers OMM1461, OMM1453, OMM1462, OMM1478, and OMM1451 failed to produce PCR product in one or more strains; further examination of these primer sequences shows that each contains one or more repeats within the primer sequence. Future use of these markers would require redesign of PCR primer pairs to determine if the failure in amplification was due to the presence of a null allele. However, many additional and useful markers are available for this species. Primers designed for OMM1461 and OMM1451 amplified in all strains but Wytheville, suggesting that PCR reactions failing to amplify these loci and/or sequencing of these regions might serve as an initial screening of Wytheville strain identity. 
The use of thirteen of the identified markers was sufficient to produce unique genotypes for each individual. However, the mean of 13.5 alleles per locus is greater than the number of individuals per strain, thus numbers of animals in the present study were not sufficient to detect all possible alleles for loci in which the number of detected alleles was greater than ten. Likewise, future studies with increased number of individuals might require the use of additional markers to successfully identify unique genotypes and provide a more complete evaluation of allelic variation (T. L. King, pers. comm.). Although unique alleles were identified in each strain, examination of additional numbers would likely decrease the number of unique alleles observed.

The observed genetic diversity ( 4 to 24 alleles) is similar to microsatellite data from Clear Springs, Troutlodge, and University of Washington strains (5 to 17 alleles, Silverstein et al., 2004), from a variety of strains (3 to 19 alleles, Palti et al., 2002), and a double haploid mapping family (2-22 alleles, Rexroad et al., 2002a). In the present study, the range of the mean number of alleles within strains (1.7) is similar to that reported by Silverstein and et al. (1.5). However the mean number of alleles per strain is less in the current study (3.7 - 6.5 as compared to 8.1-9.6 in Silverstein et al., 2004). Likewise, the overall mean number of alleles (overall genetic diversity of the loci) was greater in the current study as compared to Silverstein et al. (8.8). Thus, due to the increased variability in the number of alleles for several loci used in the present study, future use of these loci will require an increase in the number of individuals. 
In all strains, mean observed heterozygosity was less than Hardy-Weinberg expected values, indicating a loss of heterozygosity. However, within strains, some loci demonstrated heterozygosity greater than expected, indicating increased genetic diversity at these loci. Silverstein and et al. (2004) reported a range of mean within-strain heterozygosity of 69.3 to $76.3 \%$, which is greater than that observed in the current study (39.3 to 72.4\%). Rodriguez and et al. (2003) detected a range in heterozygosity of zero to $67 \%$ when examining eighteen unrelated trout, and suggested that this was due to population subdivision. Although the observed heterozygosity by Rodriguez et al.(2003) and the present study might indicate decreased genetic diversity in the hatchery strains evaluated, as previously discussed, examination of fewer individuals in these studies could have failed to detect additional allelic variation. Thus, increased numbers of individuals must be evaluated to substantiate the low heterozygosities detected for these loci. Recommended animal numbers currently range from thirty to fifty individuals (T. L. King, pers. comm.).

Observed heterozygosity over all loci for all strains was less than the expected Hardy-Weinberg value, indicating an overall loss of heterozygosity. Of particular interest is the percentage of loci in which observed heterozygosity values were less than expected (68.6\%), thus, more loci have decreased heterozygosity as compared to those that have greater than expected heterozygosity.

In the present study, $\mathrm{F}_{\text {IS }}$ values ranged from -0.0639 to 1 , and mean $\mathrm{F}_{\text {IS }}$ (over all loci and all strains) was 0.2182. For several loci (OMM1462, OMM1460, OMM1478, OMM1449, OMM1476, and OMM1445), FIS values were greater 
than 0.20 , indicating some degree of inbreeding and/or selection with respect to these loci. For marker OMM1478, FIS was equal to one, indicating complete inbreeding with respect to the locus. Mean $\mathrm{F}_{\text {IS }}$ values were high in both Wytheville (46.3\%) and Ennis (42.1\%) strains. The low number of individuals in the present study could have resulted in lack of detection of all alleles within the strains and subsequently a greater $\mathrm{F}_{\text {IS }}$ value. However, all other strains were below $32 \%$, indicating that a greater degree of inbreeding in Wytheville and Ennis strains might have occurred. The need for additional sampling of these strains is supported by observations made by Silverstein et al. (2004), who reported mean $\mathrm{F}_{\mathrm{IS}}$ values of $7.1 \%$ in an evaluation of 152 fish from three strains.

Population structure, as determined by the mean $\mathrm{F}_{\mathrm{ST}}$ value (15.3\%), was similar to previous reports in this species $(8 \%$, Hershberger, $1992 ; 8.9 \%$, Silverstein et al., 2004; 15\%, Ryman, 1983). The lowest $\mathrm{F}_{\text {ST }}$ was $9.3 \%$ (locus OMM1483), indicating that each of the 10 strains were distinct. For all loci, total inbreeding level (mean $\mathrm{F}_{\text {IT }}$ value of $33.8 \%$ ) is greater than data previously reported in this species (15\%, Silverstein et al., 2004), indicating the combined effects of inbreeding and population subdivision in the strains evaluated (Clear springs, Troutlodge, and University of Washington).

As between-strain heterogeneity tests were significant for all pair-wise comparisons of strains, each strain is considered unique. Allele frequencies allowed assignment of $92 \%$ of individuals to the correct strain of origin, regardless of low animal numbers. Similarly, accuracy of identification of stocks of Oncorhynchus nerka ranged from 89 to $96 \%$ (Beacham et al., 2002). Thus, 
these markers may prove useful in identifying strain of origin when large numbers of individuals are not available. In addition, these markers might prove useful in identification of poaching and enforcement of fishing regulations in West Virginia, as $90 \%$ of Wytheville trout were correctly identified.

As previously discussed, loss of heterozygosity, inbreeding, and a reduction in the number of individuals in a breeding program can increase the incidence of disadvantageous traits. Dollar and Katz (1964) documented the occurrence of selection and differing traits as early as 1925, thus genetic selection, and resulting differences in phenotype, has occurred in rainbow trout for many years. Also, in many strains a limited number of founders contributed to the initial broodstock. Initial selective breeding, few number of founders, combined with a newly introduced stock's response to differing hatchery environments has likely led to previously documented differences. For example, strains evaluated in the current study differ in time of spawning, percent hatch, weight at 90 days and one year, percent survival to 90 days, and tolerance to handling stresses, crowding, and transport (National Fish Strain Registry for Trout). Currently, many hatcheries actively select for traits such as spawning time and time to market (or stocking) weight, and select against undesirable phenotypes (pers. comm. with various hatchery managers). Thus, the increased levels of inbreeding observed in the present study may be due to the combined effects of these practices.

Because of a preponderance of studies conducted on wild stocks, it appears that less emphasis has been placed on genetics and maintenance of genetic variation in "put and take" as compared to restorative stocking. Although overall 
health of hatchery strains appears to be sufficient at this time, many hatchery managers noted a general increase in the incidence of undesirable traits and a decrease in hatching percentage. In addition, several managers desire outcrossing with other strains to improve the health of current stocks (pers. comm. various hatchery managers).

Overall, Wytheville strain trout appear to be the least diverse, as a decrease in genetic diversity in Wytheville trout is indicated by the fewest number of alleles per locus, least percentage of variable loci, least mean heterozygosity, greatest difference between mean observed and expected heterozygosity, and greatest $\mathrm{F}_{\text {IS }}$ values. Prior to this study, the hatchery manager (pers. comm.) expressed concern with the level of inbreeding in the Wytheville strain trout from the Petersburg State Fish Hatchery, since a general increase in the occurrence of undesirable traits (stubbed tails, incompletely formed operculum) has been observed. Selection against these undesirable traits has been ongoing, as fishes with these traits have never been used as broodstock, possibly leading to a further reduction in heterozygosity in the Wytheville strain maintained in West Virginia. In addition, current spawning methods involve pooling of collected eggs and sperm from several randomly caught individuals. This method of spawning could lead to a decrease in the number of individuals producing offspring, as previously discussed.

Examination of additional individuals maintained at the Petersburg, West Virginia hatchery would be of benefit. Comparison to Wytheville-strain rainbow trout maintained at other locations would provide additional information about the 
overall genetic variability of Wytheville rainbows, which would be of benefit to hatchery management, as they desire to integrate new broodstock into their breeding program.

Dollar and Katz (1964) discussed initial selection efforts in 1925 in both Wytheville (Virginia) and Erwin (Tennessee) rainbows, which would have resulted in a change in allele frequencies and a loss of heterozygosity in these strains. The Wytheville strain in the present study is from the West Virginia broodstock, and the Erwin strain was obtained from the Ennis hatchery in Ennis, Montana. The current study detected greater $F_{\text {IS }}$ values in Wytheville (WV) than Erwin (MT). The Wytheville (WV) strain is maintained as a distinct population, and the only introduction of broodstock was a small number of Kamloops in the 1970's. Possibly, as the Ennis hatchery maintains several strains of rainbows, other strains may have contributed to the currently maintained Erwin (MT) strain, either accidentally or intentionally, thus contributing to an increase in genetic variability as compared to the Wytheville (WV) strain. Although additional individuals must be sampled to substantiate the current results, it is likely that inbreeding has occurred in Wytheville (WV) and Ennis strains of rainbow trout, resulting in decreased heterozygosity in these strains.

\section{Implications}

The loss of heterozygosity indicated in the currenty study demonstrates the need for improved hatchery management techniques. For example, the development of distinct lines of each strain within hatcheries, spawning techniques that avoid pooling of groups of gametes, and the addition of fishes 
from either the same strain maintained at other locations and/or different strains could all be utilized to increase existing heterozygosity. Although incorporation of different broodstock into existing stocks could result in changes in stock performance, such changes might be necessary in order to decrease levels of inbreeding in these hatchery stocks. 


\section{GENE IDENTIFICATION AND EVALUATION OF RELATIVE GENE EXPRESSION IN RAINBOW TROUT (ONCORHYNCHUS MYKISS) INTESTINE, LIVER, KIDNEY, AND OVARY USING EXPRESSED SEQUENCE TAGS}

\section{INTRODUCTION}

Expressed sequence tags (ESTs) are partial complementary DNA (cDNA) sequences that represent expressed genes (mRNAs) and are identified by sequencing clones randomly selected from a cDNA library. Single-pass automated DNA sequencing of either or both of the 5' and 3' ends of cDNAs provides sequence data that can be compared readily to gene sequences contained in the National Center for Biotechnology Information (NCBI) GenBank and EST databases (Bethesda, MD). As of December, 2005, 906 species totaling 27,646,726 entries are represented in the NCBI EST database, which was initiated in 1993 (dbEST, Boguski et al., 1993). Human and mouse ESTs are represented most often, with $22 \%$ and $15.7 \%$ of all entries, respectively. Among fish species, the zebrafish (Danio rerio) is most often represented, with $2.3 \%$ of all entries.

Identification and examination of gene expression aids the study of economically important traits in commercially produced animals (Moody, 2001). Analysis of ESTs is a simple and efficient method to identify simultaneously many RNA transcripts (Adams et al., 1991). Analysis of ESTs from nonnormalized libraries (libraries from which repetitive clones have not been removed) produces relative expression profiles by examining the number of redundant clones, as the frequency of cDNAs in the library is a reflection of mRNA abundance (Okubo et al., 1992). Sequence information obtained from ESTs also can be used in micro-array-based studies. 
Much is known about the genetics, physiology, ecology, and culture of rainbow trout (Oncorhynchus mykiss; Thorgaard et al., 2002). In addition, as an aquaculturally important species, more efficient production of rainbow trout would be beneficial to producers. Kinnunen (2000) stated that genetic studies were needed to identify and develop Salmonid strains, particularly rainbow trout, with enhanced growth performance and tolerance to specific temperatures and production systems. Information obtained from rainbow trout research can be applied to other Salmonid species (Thorgaard et al., 2002). Thus, the purpose of this study was to identify novel genes and estimate relative gene expression profiles from rainbow trout liver, intestine, kidney, and ovary.

\section{MATERIALS AND METHODS}

Libraries of rainbow trout ovary libraries were prepared by using a ZAPcDNA synthesis kit (Stragagene, La Jolla, CA). Rainbow trout intestine, liver, and kidney cDNA libraries were provided by Dr. Joe Brunelli, Research Associate, at Washington State University. Libraries were prepared in $\lambda$ Zap II vectors and had a titer of approximately ten million plaque forming units (pfu) per microliter; the mass in vivo excision procedure (Stratagene, La Jolla, CA) was used to convert approximately ten million pfu of each library into a plasmid library. Bacterial cells (XL1-blue MRF') were infected with ten million of the library phage at a 10 cell:1 phage ratio and co-infected with the ExAssist helper phage (Stratagene, La Jolla, CA) at a 1:1 helper phage to cell ratio. Cells were incubated at $37^{\circ} \mathrm{C}$ for phage absorption and subsequently grown in $20 \mathrm{ml} \mathrm{LB}$ broth for 3 hours in a shaking incubator at $37^{\circ} \mathrm{C}$. During this time, phagemids 
were excised and secreted into the medium. Cells were then heated to $70^{\circ} \mathrm{C}$ for 20 min, cellular debris was removed by centrifugation, and the excised phagemids in the supernatant were titered. An overnight culture of SOLR-strain E. coli cells (Stragagene, La Jolla, CA) was infected with $10^{7}$ pfu of phagemids and incubated at $37^{\circ} \mathrm{C}$ for $15 \mathrm{~min}$. Cells were then plated onto LB plates containing $100 \mu \mathrm{g} / \mathrm{ml}$ ampicillin. Individual colonies were selected and subsequently cultured in LB liquid medium for preparation of plasmids.

Double-stranded plasmid DNA templates were prepared from each library using QIAprep Spin Miniprep Kit (Qiagen, Valencia, CA). Single-pass sequencing of the 5' ends of each cDNA clone was performed by the Sanger dideoxy termination method (Sanger et al., 1977) using Big Dye Terminator chemistry (Perkin Elmer, Foster City, CA) and T3 primer (5'AATTAACCCTCACTAAAGGG3'), as the cDNAs were directionally cloned into the $\lambda$ Zap II vectors. Approximately 200-500 ng ( $1 \mu 1)$ of plasmid DNA was used for all sequencing reactions. The profile for cycling was an initial two minute denaturation at $96^{\circ} \mathrm{C}$ followed by $96^{\circ} \mathrm{C}$ for $30 \mathrm{sec}$., $50^{\circ} \mathrm{C}$ for $15 \mathrm{sec}$., and $60^{\circ} \mathrm{C}$ for $4 \mathrm{~min}$ for 25 cycles. Sequencing products were analyzed on an ABI Prism 310 automated DNA sequencer (Perkin Elmer, Foster City, CA).

\section{Data Analysis}

Classification of clones was based on similarity to NCBI GenBank database entries (Benson et al., 1999). Vector sequence and ambiguous sequences were not included in analyses. In general, 400-450 nucleotides following the EcoRI adapter sequence were used for data base comparisons using the BLASTN and 
BLASTX algorithms (NCBI, Bethesda, MD). Matches were considered significant when the expectation value was less than 0.001 . Comparisons and alignments of the EST sequences were performed with Gene Tools 1.0 software (Edmonton, AB, Canada), and cluster analysis was performed with Stackpack 2.2 (StackPACK 2.2, Electric Genetics PTY Ltd., Reston, VA) for all sequences except these from ovarian tissues, which was performed with BioEdit v7.0.1 (Hall, T, Isis Pharmaceuticals, Inc.). To further classify EST sequences, those representing known genes were classified into 11 categories based on predicted or known functions determined by sequence similarity of annotated sequences; sequence functions were determined using NCBI Homologene, Gene Cards, Bioinformatic Harvester, PubMed, and iHOP databases. Relative expression level of genes and functional categories were estimated from the percentage of total clones that were sequenced.

\section{RESULTS}

Single-pass sequencing was performed on 281, 130, 97, and 67 clones from intestine, liver, kidney, and ovary cDNA libraries, respectively. Average length of edited ESTs obtained was $420 \mathrm{bp}$. Orthologues were identified for 68\%, 94\%, $80 \%$, and $30 \%$ of clones from intestine, liver, kidney, and ovary, respectively (Table 17). A summary of BLAST search data, clustered sequences, and redundant clones is shown in Table 17.

One hundred ninety-one clones (68\%) from the intestine cDNA library were from known genes, and 90 clones (32\%) were from unknown genes. Redundant clones were identified for 20 genes. The 191 known ESTs represented gene 
products from 139 genes, 30 of which were previously reported in rainbow trout, and the 90 clones of unknown genes represented products of 90 potential genes. Single genes with the greatest expression were $28 \mathrm{~S}$ ribosomal protein (5\%), $\mathrm{NADH}$ dehydrogenase (2.5\%), the mitochondrion complete genome (2.5\%) and beta actin (2.1\%). After caregorization by function, genes encoded binding or transport (8.5\% of all clones), enzymatic (14\%), immune system (3.5), mitochondrial (4.6\%), ribosomal (11\%), structural (4.9\%), transcriptional or translational $(4.6 \%)$, microsatellite matches $(1.8 \%)$, repeat matches $(1.8 \%)$, miscellaneous (2.8\%), and unknown (43\%) proteins (Table 18 , Figure 3). Subsequently, when all redundant clones were used as subtractants, hybridization of 3,000 randomly selected clones from the non-normalized library removed $23 \%$ of the clones.

Analysis of sequences obtained from the liver cDNA library yielded 122 clones (94\%) from known genes and 8 clones (6\%) from unknown genes. Redundant clones were identified for 13 genes. The 122 known ESTs represented products of 83 genes, 21 of which were previously reported in rainbow trout, and the 8 clones of unknown genes represented products of 6 potential genes. Serum albumin (12.3\%), apolipoprotein (5.4\%), and complement protein C-3 (4.6\%) were the most highly expressed. Genes encoded binding or transport ( $45.4 \%$ of all clones), enzymatic (17.7\%), immune system (7.7\%), mitochondrial (2.3\%), ribosomal (5.4\%), structural (1.5\%), transcriptional or translational (3.8\%), microsatellite matches $(0 \%)$, repeat matches $(0 \%)$, miscellaneous (3.8), and unknown (12.3\%) proteins (Table 19, Figure 3). As previously described for the 
intestine library, when all redundant clones were used as subtractants, hybridization of 3,000 randomly selected clones from the non-normalized library removed $39 \%$ of clones.

Analysis of sequences obtained from the kidney cDNA library yielded 78 clones (80\%) from known genes and 19 clones (20\%) from unknown genes. Redundant clones were identified for 5 genes. The 78 clones represented products of 58 genes, 12 of which were previously reported in rainbow trout, and the unknown genes represented products of 19 potential genes. Genes encoded binding or transport (17.5\% of all clones), enzymatic (8.2\%), immune system (7.2\%), mitochondrial (2.1\%), ribosomal (11.3\%), structural $(12.4 \%)$, transcriptional or translational $(3.1 \%)$, microsatellite matches $(1 \%)$, repeat matches (0\%), miscellaneous (4.1\%), and unknown (33\%) proteins (Table 18, Figure 3). The most abundant genes were beta actin (13\%) and $28 \mathrm{~S}$ ribosomal protein $(6.2 \%)$. Subsequently, when beta actin and $28 \mathrm{~S}$ ribosomal protein were used as subtractants, hybridization of 3,000 randomly selected clones from the non-normalized library removed $21.7 \%$ of clones.

Twenty clones (30\%) from the ovary cDNA library were from known genes and 47 clones (70\%) were from unknown genes. Redundant clones were identified for four genes. The 20 known ESTs represented gene products from 16 genes, four of which were previously reported in rainbow trout, and the 47 clones of unknown genes represented products of 46 potential genes. Genes with the greatest expression were $\mathrm{NAD}(\mathrm{P}) \mathrm{H}$ dehydrogenase $(3 \%)$, ribosomal protein L35 (3\%), G-protein (P-Ras, 3\%), and alpha-2 macroglobulin (3\%). Genes encoded 
binding or transport ( $6 \%$ of all clones), enzymatic (3\%), immune system (1.5\%), ribosomal (3\%), transcriptional or translational (1.5\%), miscellaneous $(6 \%)$, and unknown (79.1\%) proteins (Table 18, Figure 3).

Putative identifications matching those previously reported for other species are shown in Table 20. Many genes were found in two tissues, and clones containing sequences homologous to the mitochondrion genome, polyubiquitin, and ribosomal protein L3 were found in intestine, kidney, and liver (Table 20). For genes previously identified in rainbow trout, for all tissues combined 149 clones represented the products of 54 genes. For individual tissues, 74 clones from the intestine library represented 30 genes, 30 clones from the kidney library represented 12 genes, 38 clones from the liver library represented 21 genes, and 5 clones from the ovary library represented 5 genes.

\section{DISCUSSION}

Expressed sequence tags have proven to be an extremely useful method of gene identification. The rainbow trout is an economically important agricultural species, and its usefulness as an animal model has been clearly documented (Thorgaard et al., 2002). Although large-scale EST identification and annotation for this species is ongoing (Rexroad et al., 2003), the rainbow trout is represented by only $0.8 \%$ of all entries, and over $99 \%$ of those were been added between 2002-2005. Currently, 906 species are represented in the NCBI EST database (dbEST, Boguski et al., 1993), totaling 27,646,726 entries. Species such as Bos taurus (cow), Gallus gallus (chicken), and Sus scrofa (pig) represent 2.2\%, 2\%, and $1.6 \%$ of entries, respectively. Identification of additional ESTs for rainbow 
trout is of benefit, as sequence information from rainbow trout expressed sequence tags contained within the public databases has facilitated additional studies in this species (Douglas et al., 2003; Laing and Secombes, 2004; Hansen et al., 2005; Katoh, 2005; Krasnov et al., 2005; Srivastava et al., 2005; vonSchalburg et al., 2005).

In the present study, the percentage of unknown genes ranged from $6 \%$ (liver) to $70 \%$ (ovary). The percentage of unknown ESTs from the liver library (20\%) is the same as that reported by Kono et al. (2002). As a farmed species, fertility is of great importance in the culture of rainbow trout. Many testis ESTs have been reported and utilized to develop macro-array-based expression profiles during spermatogenesis (Mazurais et al., 2005), however, the present study identified many unknown ESTs in the ovary library and no reports of ovary-derived EST sequences are available. Thus, further examination of ovarian genes, in combination with information provided by Mazurais and et al., might provide information to maximize fertility in farmed stocks.

Non-normalized cDNA libraries can provide relative expression profiles (Patanjali et al., 1991). In the present study of rainbow trout intestine, liver, kidney, and ovary, several genes produced the major transcription products of the respective cell types. For example, in the liver cDNA library, serum albumin ESTs were $12 \%$ of total clones sequenced. This is similar to data reported for Atlantic salmon (Salmo salar), in which serum albumin was represented by $16 \%$ of all clones in a liver cDNA library (Byrnes and Gannon, 1990). In addition, 30 genes were found in more than one tissue, suggesting housekeeping functions for 
these genes. Possibly, PCR primers developed from sequence information in these genes could serve as positive controls in future studies, although Kono and et al. (2000) failed to find common ESTs in both kidney and gill clones. Thus, further evaluation of these ESTs is warranted.

One advantage of analysis of ESTs from non-normalized libraries is the ability to produce relative expression profiles by examining the number of redundant clones, as the frequency of cDNAs in the library is a reflection of mRNA abundance. For the purpose of gene discovery, repeated isolation and subsequent sequencing of highly expressed genes is undesirable, thus normalized or subtracted libraries are needed for characterization of large numbers of unique ESTs (Patanjali et al., 1991; Sasaki et al., 1994). Hybridization of randomly selected clones was $21.7 \%$ when beta actin and $28 \mathrm{~S}$ ribosomal protein were used as subtractants, which is similar to the predicted value of $19 \%$ as estimated from the number of redundant clones. Hybridization performed with non-normalized intestine and liver libraries removed $23 \%$ and $39 \%$ of the 3000 clones respectively. Thus, the construction of subtracted cDNA libraries might facilitate discovery of additional genes and cataloging ESTs for functional genomic studies in this species.

Previous reports have suggested that genetic studies similar to those performed in other meat-producing species were needed to identify and develop Salmonid strains with enhanced growth performance (Kinnunen, 2000). If this is to become a reality, additional rainbow trout genes must be identified, and future 
studies examining the function and differential expression of these genes must be performed. 


\section{REFERENCES}

Adams MD, Kelley JM, Gocayne JD, Dubnick M, Polymeropoulos MH, Xiao H, Merril CR, Wu A, Olde B, Moreno RF, Kerlavage AR, McCombie WR, Venter JC. 1991. Complementary DNA sequencing: expressed sequence tags and human genome project. Science. 252:1651-6.

Akulin VH, Svetaskev FI, Salmenkova EA. 1975. Intraspecies genetic variations of blood serum phospholipids of the red salmon Oncorhynchus nerka and the keta Oncorhynchus keta. Journal of Journal of Evolutionary Biochemistry and Physiology. (USSR). 11: 262-264.

Allendorf FW, Utter FM. 1973. Gene duplication within the family Salmonidae: disomic inheritance of two loci reported to be tetrasomic in rainbow trout. Genetics. 74: 647-654.

Allendorf FW. 1975. Genetic variability in a species possessing extensive gene duplication; genetic interpretation of duplicate loci and examination of genetic variation in populations of rainbow trout. Ph.D. Thesis, University of Washington, Seattle, WA. In. Hershberger WK. 1992. Genetic variability in rainbow trout populations. Aquaculture. 100: 51-71.

Allendorf FW, RymanN, Stenneck A, Stahl G. 1976. Genetic variation in Scandinavian populations of brown trout: Evidence of distict sympatric populations. Hereditas. 83: 73-82.

Allendorf FW, Utter FM. 1976. Gene duplication in the family Salmonidae: III. Linkage between two duplicated loci coding for aspartate aminotransferase in the cutthroat trout. Hereditas. 82: 19-24.

Allendorf FW, Mitchell NJ, Ryman N, Stahl G. 1977. Isozyme loci in brown trout (Salmo trutta L.): detection and interpretation from population data. Hereditas. 86: 179-190.

Allendorf FW. 1977. Electromorphs or alleles? Genetics. 87: 821-822.

Allendorf FW. 1978. Electrophoretic distinction of rainbow trout (Salmo gairdneri) and cutthroat trout (S. clarki). Letter to the editor. Journal of the Fisheries Research Board of Canada. 35: 483.

Allendorf FW, Phelps SR. 1980. Loss of genetic variation in a hatchery stock of cutthroat trout. Transactions of the American Fisheries Society. 109: 537-543.

Allendorf FW, Phelps SR. 1981. Isozymes and the preservation of genetic variation in salmonid fishes. Ecological Bulletin. (Stockholm). 34: 37-52. 
Allendorf FW, Stahl G, Ryman N. 1984. Silencing of duplicate genes: Evidence for a common null allele polymorphism for lactate dehydrogenase in brown trout (Salmo trutta). Molecular Biology and Evolution. 1: 183-194.

Allendorf FW, Seeb JE, Knudsen KL, Thorgaard GH, Leary RF. 1986. Genecentromere mapping of 25 loci in rainbow trout. Journal of Heredity. 77: 307312.

Allendorf FW, Ryman N, Utter FM. 1987b. Genetics and fishery management: past, present, and future. In Ryman N, Utter F, editors. Population Genetics \& Fishery Management. University of Washington Press, Seattle, WA: 1-19.

Allendorf FW, Ryman N. 1987a. Genetic management of hatchery stocks. In Ryman N, Utter F, editors. Population Genetics \& Fishery Management. University of Washington Press, Seattle, WA: 141-159.

Allendorf FW. 1988. Conservation biology of fishes. Conservation Biology. 2: $145-148$.

Allendorf FW, Leary RF. 1988. Conservation of genetic variation in a polytypic species, the cutthroat trout. Conservation Biology. 2: 170-184.

Allendorf FW, Gellman WA, Thorgaard GH. 1994. Sex linkage of two enzyme loci in rainbow trout. Heredity. 72: 498-507.

Allendorf FW, Seeb LW. 2000. Concordance of genetic divergence among sockeye salmon populations at allozyme, nuclear DNA, and mtDNA markers. Evolution. 54: 640-651.

Allendorf FW. 2001. Whirling disease and wild trout: Darwinian fisheries management. Fisheries (Bethesda). 26: 27-29.

Altukhov YP. 1981. The stock concept from the viewpoint of population genetics. Canadian Journal of Fisheries and Aquatic Sciences. 38: 1523-1528.

Alm G. 1949. Influence of heredity and environment on various forms of trout. Reports of the Institute for Freshwater Research, Drottingholm. 29: 29-34.

Anderson L, Ryman N, Stahl G. 1983. Protein loci in the Arctic char, Salvelinus alpinus L.: electrophoretic expression and genetic variability patterns. Journal of Fish Biology. 23: 75-94.

Angers B, Bernatchez L, Angers A, Desgroseillers L. 1995. Specific microsatellite loci for brook char reveal strong population subdivision on a microgeographic scale. Journal of Fish Biology. 47 (suppl A), 177-185. 
Angers B, Bernatchez L. 1996. Usefulness of heterologous microsatellites obtained from brook char, Salvelinus fontiinalis Mitchill, in other Salvelinus species. Molecular Ecology. 5: 317-319.

Angers B, Bernatchez L. 1997. Complex evolution of a salmonid microsatellite locus and its consequences in inferring allelic divergence from size information. Molecular Biology and Evolution. 14: 230-238.

Aparicio E, Garcia-Berthou E, Araguas RM, Martinez P, Garcia-Marin JL. 2005. Body pigmentation pattern to assess introgression by hatchery stocks in native Salmo trutta from Mediterranean streams. Journal of Fish Biology. 67: 931-949.

Apostolidis A, Karakousis Y, Triantaphyllidis C. 1996, Genetic differentiation and phylogenetic relationships among Greek Salmo truttai L. (brown trout) populations as revealed by RFLP analysis of PCR amplified mitochondrial DNA segments. Heredity. 77: 608-618.

Apostolidis A, Triantaphyllidis C, Kouvatsi A, Economidis PS. 1997. Mitochondrial DNA sequence variation and phylogeography among Salmo trutta L. (Greek brown trout) populations. Molecular Ecology. 6: 531-542.

Arden WR, Borer S, Thrower F, Joyce JE, Kapuscinski AR. 1999. Inheritance of 12 microsatellite loci in Oncorhynchus mykiss. Journal of Heredity. 90: 529536.

Arias J, Sanchez L, Martinez P. 1995. Low stocking incidence in brown trout populations from north-western Spain monitored by LDH-5* diagnostic marker. Journal of Fish Biology. 47 (Suppl. A), 170-176.

Ashwell MS, Da Y, Vanraden PM, Rexroad CE Jr., Miller RH. 1998. Detection of putative loci affecting conformational type traits in an elite population of United States Holsteins using microsatellite markers. Journal of Dairy Science. 81: 1120-1125.

Aspinwall N. 1973a. Inheritance of alpha-glycerophosphate dehydrogenase in the pink salmon, Oncorhynchus gorbuscha (Walbaum). Genetics. 73: 639-641.

Aspinwall N. 1974. Genetic analysis of North American populations of the pink salmon (Oncorhynchus gorbuscha): Possible evidence for the neutral mutationrandom drift hypothesis. Evolution. 28: 295-305.

Aulstad D, Kittlesen A. 1971. Abnormal body curvatures of rainbow trout (Salmo gairdneri) inbred fry. Journal of the Fisheries Research Board of Canada. 28: 1918-1920. 
Avise JC. 1994. Molecular Markers, natural history and Evolution. New York, NY: Chapman \& Hall.

Ayles GB. 1975. Influence of genotype and the environment on growth and survival of rainbow trout (Salmo gairdneir) in central Canadian aquaculture lakes. Aquaculture. 6: 181-188.

Ayles GB. 1979. Genetic differences in lipid and dry matter content between strains of rainbow trout (Salmo gairdneri) and their hybrids. Aquaculture. 18: 253-262.

Ayala FJ. 1984. Molecular polymorphism: How much is there and why is there so much? Developmental Genetics. 4: 379-391.

Bagley MJ. 1994. A genetic evaluation of the influence of stocking density on the early growth of rainbow trout (Oncorhynchus mykiss). Aquaculture. 121: 313-326.

Bagley MJ. 1997. Polymorphic molecular markers from anonymous nuclear DNA for genetic analysis of populations. Molecular Ecology. 6: 309-320.

Bagley MJ, Gall GAE. 1998. Mitochondrial and nuclear DNA sequence variability among populations of rainbow trout (Oncorhynchus mykiss). Molecular Ecology. 7: 945-961.

Bagley MJ, Franson SE, Christ SA, Waits ER, Toth GP. 2002. Genetic diversity as an indicator of ecosystem condition and sustainability: utility for regional assessments of stream condition in the eastern United States. U. S. Environmental Protection Agency, Cincinnati, OH. EPA/600/R-03/056

Bailey GS, Tsuyuki H, Wilson AC. 1968. The number of genes for lactate dehydrogenase in salmonid fishes. Journal of the Fisheries Research Board of Canada. 33: 760-767.

Bailey GS, Wilson AC, Halver JE, Johnson CL. 1970. Multiple forms of supernatant malate dehydrogenase in salmonid fishes. Journal of Biological Chemistry. 245: 5927-5940.

Balloux F, Brunner H, Lugon-Moulin N, hausser J, Goudet J. 2000.

Microsatellites can be misleading: an empirical and simulation study. Evolution. 54: 1414-1422.

Banks MA, Baldwin BA, Hedgecock D. 1996. Research on chinook salmon (Oncorhynchus tshawytscha) stock structure using microsatellite data. Bulletin of the National Research Institute of Aquaculture. 2 (Suppl.): 5-9. 
Banks MA, blouin MS, Baldwin BA, Rashbrook VK, Fitzgerald HA, Blankenship SM, Hedgecock D. 1999. Isolation and inheritance of novel microsatellites in chinook salmon (Oncorhynchus tshawytscha). Journal of Heredity. 90: 281-288.

Banks MA, Rashbrook VK, Calavetta MJ, Dean CA, Hedgecock D. 2000. Analysis of microsatellite DNA resolves genetic structure and diversity of Chinook salmon (Oncorhynchus tshawytscha) in California's Central Valley. Canadian Journal of Fisheries and Aquatic Sciences. 57: 1-12.

Bartholomew JL. 2001. Inheritance of resistance to Ceratomyxa shasta in progeny from crosses between high- and low-susceptibility strains of rainbow trout (Oncorhynchus mykiss). Bulletin of National Research Institute of Aquaculture. Supplement 5, pp. 71-75.

Bartley D. 1992. Use of linkage disequilibrium data to estimate effective size of hatchery and natural fish populations. Conservation Biology. 6: 365-375.

Beacham TD, Withler RE, Goupd AP. 1985. Biochemical genetic stock identification of chum salmon (Oncorhynchus keta) in southern British Columbia. Canadian Journal of Fisheries and Aquatic Sciences. 42: 437-448.

Beacham TD, Gould AP, Withler RE, Murray CB, Barner LW. 1987. Biochemical genetic survey and stock identification of chum salmon (Oncorhynchus keta) in British Columbia. Canadian Journal of Fisheries and Aquatic Sciences. 53: 380-394.

Beacham TD, Withler RE, Wood CC. 1995. Stock identification of chinook salmon using minisatellite DNA variation. North American Journal of Fisheries Management. 15: 249-265.

Beacham TD, Withler RE, Stephens TA. 1996. Stock identification of chinook salmon (Oncorhynchus tshawytscha) using minisatellite DNA variation. Canadian Journal of Fisheries and Aquatic Sciences. 53: 380-394.

Beacham TD, Miller KM, Withler RE. 1996. Minisatellite DNA variation and stock identification of coho salmon. Journal of Fish Biology. 49: 411-429.

Beacham TD, Dempson JB. 1998. Population structure of Atlantic salmon from the Conne River, Newfoundland as determined from microsatellite DNA. Journal of Fish Biology.. 52: 665-676.

Beacham TD, Le KD, Raap MR, Hyatt K, Luedke W, Wither RE. 2000a. Microsatellite DNA variation and estimation of stock composition of sockeye salmon, Oncorhynchus nerka, in Barkley Sound, British Columbia. Fishery Bulletin. 98: 14-24. 
Beacham TD, Wood CC, Withler RE, Miller KM. 2000b. Application of microsatellite DNA variation to estimation of stock composition and escapement of Skeena River sockeye salmon (Oncorhynchus nerka). North Pacific Anadromous fish Commission Bulletin. 2: 263-276.

Beecham TD, Candy JR, Supernault KJ, Ming T, Deagle B, Schultz A, Tuck D, Kaukinen K, Irvine JR, miller KM, Withler RE. 2001. Evaluation and application of microsatellite and major histocompatability complex in variation for stock identification of coho salmon in British Columbia. Transactions of the American Fisheries Society. 130: 1116-1155.

Beacham TD, McIntosh B, MacConnachie C. 2002. Microsatellite identification of individual sockeye salmon in Barkley Sound, British Columbia. Journal of Fish Biology. 61: 1021-1032.

Beacham T, Supernault KJ, Wetklo M, Deagle B, Labaree L, Irvine J, Candy J, Miller k, Nelson RJ, Withler R. 2003a. The geographic basis for population structure in Fraser River chinook salmon (Oncorhynchus tshawytscha) Fishery Bulletin 101, 229-242.

Beacham TD, Candy JR, supernault KJ, Wetklo M, Deagle B, Labaree K, Irvine JR, Miller KM, Nelson RJ, Withler RE. 2003b. Evaluation and application of microsatellites for population identification of Fraser river chinook salmon (Oncorhynchus tshawytscha). Fishery Bulletin. 101: 243-259

Behnke RJ. 1979. The native trouts of the genus Salmo of western North America. Monograph for U.S.D.A., Forest Service, Fish and Wildlife Service, and Bureau of Land Management, Lakewood, CO.

Behnke RJ. 1992. Native trout of western North America. American Fisheries Society, Bethesda, MD.

Bensen DA, Boguski MS, Lipman DJ, Ostell, J, Francis Ouellette, BF, Rapp, BA, Wheeler, DL. 1999. GenBank. Nucleic Acids Research. 27: 38-43.

Bentzen P, Wright JM. 1993. Nucleotide sequence and evolutionary conservation of a minisatellite variable number tandem repeat cloned from Atlantic salmon, Salmo salar. Genome. 36: 271-277.

Bernatchez L, Guyomard R, Bonhomme F. 1992. DNA sequence variation of the mitochondrial control region among geographically and morphologically remote European brown trout Salmo trutta populations. Molecular Ecology. 1: 161-173.

Bernatchez L, Danzmann RG. 1993. Congruence in control-region sequence and restriction site variation in mitochondrial DNA of brook charr (Salvelinus fontinalis Mitchell). Molecular Biology and Evolution. 10: 1002-1014. 
Bernatchez L, Osinov A. 1995. Genetic diversity of trout (genus Salmo) from its most eastern native range based on mitochondrial DNA and nuclear gene variation. Molecular Ecology. 4: 285-297

Bernatchez L, Glemet H, Wilson CC, Danzmann RG. 1995. Introgression and fixation of Arctic char (Salvelinus alpinus) mitochondrial genome in allopatric population of brook trout (Salvelinus fontinalis). Canadian Journal of Fisheries and Aquatic Sciences. 52: 179-185.

Bernatchez L, Duchesne P. 2000. Individual-based genotype analysis in studies of parentage and population assignment: how many loci, how many alleles? Canadian Journal of Fisheries and Aquatic Sciences. 57: 1-12

Bernatchez L. 2001. The evolutionary history of brown trout (Salmo trutta L.) inferred from phylogeographic, nested clade and mismatch analyses of mitochondrial DNA variation. Evolution. 55: 351-379.

Berrebi P, Poteaux C, Fissier M, Cattaneo-Berrebi G. 2000. Stocking impact and allozyme diversity in brown trout from Mediterranean southern France. Journal of Fish Biology. 56: 949-960.

Bickham JW, Wood CC, Patton JC. 1995. Biogeographic implications of cytochrome b sequences and allozymes in sockeye (Oncorhynchus nerka). Journal of Heredity. 86: 140-144.

Blanco G, Sanchez JA, Vazquez E, Rubio J, Utter FM. 1992. Genetic differentiation among natural European populations of Atlantic salmon (Salmo salar) from drainages of the Atlantic Ocean. Animal Genetics. 23: 11-18.

Blanco G, Ramos MD, Vazquez E, Sanchez JA. 2005. Assessing temporal and spatial variation in wild populations of Atlantic salmon with particular reference to Asturias (Northern Spain) rivers. Journal of Fish Biology. 169-184.

Blouin MS, Parsons M, Lacaille V. Lotz S. 1996. Use of microsatellite loci to classify individuals by relatedness. Molecular Ecology. 5: 393-401.

Boguski MS, Lowe TM, Tolstoshev CM. 1993. dbEST--database for "expressed sequence tags." Nature Genetics. 4: 332-3.

Bonnet S, Vauchez C, Faure A, Fauconneau B, Haffray P, Blanc JM, Vallee F. 1999. Genetic variation in growth parameters until commercial size in diploid and triploid freshwater rainbow trout (Oncorhynchus mykiss). And seawater brown trout (Salmo trutta). Aquaculture. 173: 359-375. 
Bourke EA, Coughlan J, Jansson H, Galvin P, Cross TF. 1997. Allozyme variation in populations of Atlantic salmon located throughout Europe: diversity that could be compromised by introductions of reared fish. ICES Journal of Marine Science. 54: 974-985.

Broman KW. 2001. Review of statistical methods for QTL mapping in experimental crosses. Lab Animal 30: 44-52.

Bruford MW, Bradley DG, Luikart G. 2003. DNA markers reveal the complexity of livestock domestication. Nature Reviews-Genetics. 4: 900-910.

Brykov VA, Polyakova N, Skurikhina LA, Kukhlevsky AD, Kirillova ON, Churikov D, Pudovkin AI, Charrett AJ. 1999. Analysis of mtDNA indicates weak temporal genetic heterogeneity in pink salmon spawning runs in two rivers on Sakhalin Island. Journal of Fish Biology. 55: 617-635.

Busack CA, Halliburton R, Gall GAE. 1979. Electrophoretic variation and differentiation in four strains of domesticated rainbow trout (Salmo gairdneri). Can. J. Genet. Cytol. 21: 81-94.

Busack CA, Thorgaard GH, Bannon MP, Gall GAE. 1980. An electrophoretic, karyotypic and meristic characterization of the Eagle Lake trout, Salmo gairdneri aquilarum. Copeia. 1980: 418-424.

Busack CA, Gall GAE. 1981. Introgressive hybridization in populations of Paiute cutthroat trout (Salmo clarki seleniris). Canadian Journal of Fisheries and Aquatic Sciences 38: 939-951.

Byrnes L, Gannon F. 1990. Atlantic salmon (Salmo salar) serum albumin: cDNA sequence, evolution, and tissue expression. DNA and Cell Biology. 9: 647-55.

Campton DE, Johnson JM. 1985. Electrophoretic evidence for a genetic admixture of native and nonnative rainbow trout in the Yakima River, Washington. Transactions of the American Fisheries Society. 114: 782-793.

Campton DE, Utter FM. 1987. Genetic structure of anadromous cutthroat trout (Salmo clarki clarki) populations in the Puget Sound area: Evidence for restricted gene flow. Canadian Journal of Fisheries and Aquatic Sciences 44: 573-582.

Campton DE, Allendorf FW, Behnke RJ, Utter FM. 1991. Reproductive success of hatchery and wild steelhead: A reanalysis. Transactions of the American Fisheries Society. 120: 816-822

Carrera E, Sanz B, Hernandez PE, Martin R, Garcia T, Cespedes A, Gonzalez I. 1998. Identification of Atlantic salmon (Salmo salar) and rainbow trout 
(Oncorhynchus mykiss) by using polymerase chain reaction amplification and restriction analysis of the mitochondrial cytochrome b gene. Journal of Food Protection. 61: 482-486.

Carrera E, Garcia T, Cespedes, A, Gonzalez I, Fernandez A, Hernandez PE, Martin R. 1999a. PCR-RFLP of the mitochondrial cytochrome oxidase gene: a simple method for discrimination between Atlantic salmon (Salmo salar) and rainbow trout (Oncorhynchus mykiss). Journal of the Science of Food and Agriculture. 79: 1654-1658.

Carrera E, Fernandez A, Hernandez PE, Martin R, Garcia T, Cespedes A, Gonzales I. 1999b. Salmon and trout analysis by PCR-RFLP for identity authentication. Journal of Food Science. 64: 410-413.

Carrera E, Garcia T, Cespedes, A, Gonzalez I, Fernandez A, Asensio LM, Hernandez PE, Martin R. 2000a. Differentation of smoked Salmo salar, Oncorhynchus mykiss, and Brama raii using nuclear marker 5S rDNA. International Journal of Food Science and Technology. 35: 401-406.

Carrera E, Garcia T, Cespedes, A, Gonzalez I, Fernandez A, Asensio LM, Hernandez PE, Martin R. 2000b. Identification of smoked Atlantic salmon (Salmo salar) and rainbow trout (Oncorhynchus mykiss) using PCR-restriction fragment length polymorphism of the p53 gene. Journal of the AOAC International. 83: 341-346.

Cavalli-Sforza LL, Edwards AWF. 1967. Phylogenic analysis: models and estimation procedures. Evolultion 21: 550-570.

Cederbaum SD, Yoshida A. 1972. Tetrazolium oxidase polymorphism in rainbow trout. Genetics. 72: 363-367.

Chakraborty R, Haag M, Ryman N, Stahl G. 1982. Hierarchical gene diversity analysis and its application to brown trout populations data. Hereditas. 97: 1721.

Chakraborty R, Jin L. 1993. Determination of relatedness between individuals using DNA fingerprinting. Human Biology. 65: 875-895.

Chapman DG, Mathisen OA. 1987. Foreward. Population Genetics and Fishery Management. pp. vii. Ryman N, Utter F, eds. University of Washington Press, Seattle, WA.

Chevassus B, Dupont-Nivet M, Mauger S, Haffray P, Vandeputte M. 2002. Estimation of heritabilities in two groups of rainbow trout (Oncorhynchus mykiss) with families mixed together since eyed stage. Proceedings of the $7^{\text {th }}$ World Congress on Genetics Applied to Livestock Production, Montpellier, France. 
Chilcote MN, Crawford BA, Leider SA. 1980. A genetic comparison of sympatric populations of summer and winter steelheads. Transactions of the American Fisheries Society. 109: 203-208.

Chilcote MW, Leider SA, Loch JJ. 1986. Differential reproductive success of hatchery and wild summer-run steelhead under natural conditions. Transactions of the American Fisheries Society. 115: 726-735.

Chilcote MW, Leider SA, Loch JJ. 1991. Comments: Reproductive success of hatchery and wild steelhead. Transactions of the American Fisheries Society. 120: $822-827$.

Clifford SL, McGinnity P, Ferguson A. 1998. Genetic changes in an Atlantic salmon population resulting from escaped juvenile farm salmon. Journal of Fish Biology. 52: 118-127.

Colihueque N, Vergara N, Parraguez M. 2003. Genetic characterization of naturalized populations of brown trout Salmo trutta L. in southern Chile using allozyme and microsatellite markers. Aquaculture Research. 34: 525-533.

Cordes JF, Perkins DL, Kincaid HL, May B. 2005. Genetic analysis of fish genomes and populations: allozyme variation within and among Atlantic salmon from Downeast rivers of Maine. Journal of Fish Biology. 67: (suppl. A): 104117.

Cornuet JM, Piry S, Luikart G, Estoup A, Solignac M. 1999. New methods employing multilocus genotypes to select or exclude populations as origins of individuals. Genetics. 153: 1989-2000.

Corujo M, Blanco G, Vazquez E, Sanchez JA. 2004. Genetic structure of northwestern Spanish brown trout (Salmo trutta L.) populations, differences between microsatellite and allozyme loci. Hereditas. 141: 258-271.

Coulibaly I, Gharbi K, Danzmann RG, Yao J, Rexroad CE. 2005.

Characterization and comparison of microsatellites derived from repeat-enriched libraries and expressed sequence tags. Animal Genetics. 63: 309-315.

Crandell PA, Gall GAE. 1993a. The genetics of body weight and its effect on early maturity based on individually tagged rainbow trout (Oncorhynchus mykiss). Aquaculture. 117: 77-93.

Crandell PA, Gall GAE. 1993b. The genetics of age and weight at sexual maturity based on individually tagged rainbow trout (Oncorhynchus mykiss). Aquaculture. 117: 95-105. 
Crawford BA. 1979. A study of the contribution of hatchery-reared summer steelhead to wild steelhead recruitment through the use of genetic markers. 1619.

Crespi BJ, Fulton MJ. 2004. Molecular systematics of Salmonidae: combined nuclear data yields a robust phylogeny. Molecular Phylogenetics and Evolution. 31: $658-679$.

Cronin MA, Spearman WJ, Wilmot RL, Patton JC, Bickhan JW. 1993. Mitochondrial DNA variation in chinook (Oncorhynchus tshawytscha) and chum salmon $(O$. keta) detected by restriction enzyme analysis of polymerase chain reaction (PCR) products. Canadian Journal of Fisheries and Aquatic Sciences. 50: $708-714$.

Cross TF, Ward RD. 1980. Protein variation and duplicate loci in the Atlantic salmon, Salmo salar L. Genetical Research. 36: 147-165

Cross TF, King J. 1983. Genetic effects of hatchery rearing in Atlantic salmon. Aquaculture. 33: 33-40.

Crozier WW. 1984. Electrophoretic identification and comparative examination of naturally occurring $\mathrm{F}_{1}$ hybrids between brown trout (Salmo trutta $\mathrm{L}$.) and Atlantic salmon (S. salar L.). Comparative Biochemistry and Physiology. Vol. 78B: 785-790.

Crozier WW, Fergson A. 1986. Electrophoretic examination of the population structure of brown trout, Salmo trutta L., from the Louth Neagh catchment, Northern Ireland. Journal of Fish Biology. 28: 459-477.

Crozier WW, Moffett IJ. 1989. Amount and distribution of biochemical genetic variation among wild populations and hatchery stocks of Atlantic salmon (Salmo salar) from north-east Ireland. Journal of Fish Biology. 35: 665-677. [too old for online]

Currens KP, Schreck CB, Li HW. 1990. Allozyme and morphological divergence of rainbow trout (Oncorhynchus mykiss) above and below waterfalls in Deschutes River, Oregon. Copeia. 730-746.

Dakin EE, Avise JC. 2004. Microsatellite null alleles in parentage analysis. Heredity. 93: 504-509.

Danielsdottir AK, Marteinsdottir G, arnasson F, Gudjonsson S. 1997. Genetic structure of wild and reared Atlantic salmon (Salmo salar) populations in Iceland. ICES Journal of marine Science. 54: 986-997. 
Danzmann RG, Ferguson MM, Allendorf FW. 1985a. Does enzyme heterozygosity influence developmental rate in rainbow trout? Heredity. 56: 417-425.

Danzmann RG, Ferguson MM, Allendorf FW. 1985b. Allelic differences in initial expression of paternal alleles at an isocitrate dehydrogenase locus in rainbow trout. Developmental Genetics. 5: 117-127.

Danzmann RG, Ferguson MM, Allendorf FW, Knudsen KL. 1986. Heterozygosity and development rate in a strain of rainbow trout (Salmo gairdneri). Evolution. 40: 86-93.

Danzmann RG. 1988a. Temperature-dependent genotypic selection and embryonic survival of rainbow trout. Biochemical Genetics. 26: 69-81.

Danzmann RG. 1988b. Developmental rates of heterozygous and homozygous rainbow trout reared at three temperatures. Biochemical Genetics. 26: 53-67.

Danzmann RG, Ferguson MM, Allendorf FW. 1989. Genetic variability and components of fitness in hatchery strains of rainbow trout. Journal of Fish Biology. 35(Suppl. A): 313-319.

Danzmann RG. 1991. Mitochondrial DNA diversity among four sympatric morphs of Arctic charr, Salvelinus alpinus L., from Thingvallavatn, Iceland. Journal of Fish Biology. 39: 649-659.

Danzmann RG. 1993. Mitochondrial DNA variability in Ontario and New York rainbow trout (Oncorhynchus mykiss). Canadian Journal of Zoology. 71: 19231933.

Danzmann RG, Ferguson MM, Heculuck DM. 1994. Heterogeneity in the distribution of mitochondrial DNA haplotypes in female rainbow trout spawning in different seasons. Canadian Journal of Fisheries and Aquatic Sciences. 51 (suppl 1): 284-289.

Danzmann RG, Ihssen PE. 1995. A phylogeographic survey of brook charr (Salvelinus fontinalis) in Algonquin Park, Ontario based upon mitochondrial DNA variation. Molecular Ecology. 4: 681-697.

Danzmann RG, Ferguson MM, Jackson TR. 1999. Epistasis in allelic expression at upper temperature tolerance QTL in rainbow trout. Aquaculture. 173: 45-58.

Danzmann RG, Gharbi K. 2001. Gene mapping in fishes: a means to an end. Genetics. 111: 3-23. 
Daugherty DJ, Sutton TM, Greil RW. 2003. Life-history characteristics, population structure, and contribution of hatchery and wild steelhead in a Lake Huron tributary. Journal of Great Lakes Research. 29: 511-520.

Delany ME, Bloom SE. 1984. Replication banding patterns in the chromosomes of the rainbow trout. Journal of Heredity. 75: 431-434.

Dietrich W, katz H, Lincoln et al., 1992. A genetic map of the mouse suitable for typing intraspecific crosses. Genetics. 131: 423-447.

Digby TJ, Gray MW, Lazier CB. 1992. Rainbow trout mitochondrial DNA: sequence and structural characteristics of the non-coding control region and flanking tRNA genes. Gene. 118: 197-204.

Docker MF, Dale A, Heath DD. 2003. Erosion of interspecific reproductive barriers resulting from hatchery supplementation of rainbow trout sympatric with cutthroat trout. Molecular Ecology. 12: 3515-3521.

Dollar AM, Katz M. 1964. Rainbow trout brood stocks and strains in American hatcheries as factors in the occurrence of hepatoma. Progressive Fish Culturist. 26: $167-174$.

Douglas SE, Gallant JW, Liebscher RS, Dacanay A, Tsoi SCM. 2003. Identification and expression analysis of hepcidin-like antimicrobial peptides in bony fish. Developmental \& Comparative Immunology. 27: 589-602.

Dueck LA, Danzmann RG. 1996. Matriarchal population structure of introduced rainbow trout (Oncorhynchus mykiss) in the Lake Ontario watershed. Canadian journal of Fisheries and Aquatic Sciences. 53: 2100-2114.

Dunham RA, Smitherman RO. 1983. Response to selection and realized heritability for body weight in three strains of channel catfish, Ictalurus punctatus, grown in earthen ponds. Aquaculture. 33: 88-96.

Dunham RA, Majumdar K, Hallerman E, Bartley D, Mair G, Hulata G, Liu, Z, Pongthana N, Bakos J, Penman D, Gupta M, Rothlisberg P \& Hoerstgen-Schwark G. 2001. In R.P. Subasinghe, P. Bueno, M.J. Phillips, C. Hough, S.E. McGladdery \& J.R. Arthur, eds. 2000. Review of the status of aquaculture genetics. Aquaculture in the Third Millennium. Technical Proceedings of the Conference on Aquaculture in the Third Millennium, Bangkok, Thailand..137166. NACA, Bangkok and FAO, Rome.

Epplen JT, McCarrey JR, Sutou S, Ohno S. 1982. Base sequence of a cloned snake W-chromosome DNA fragment and identification of a male-specific putative mRNA in the mouse. Proceedings of the National Academy of Sciences, USA. 79: 3798-3802. 
Epplen JT, Melmer G, Schmidt P, Roewer L, Hundrieser J, Epplen C, Buitkamp J. 1992. On the potential of simple repetitive DNA for fingerprinting in clinical, forensic, and evolutionary dynamic studies. Clinical Investigation. 70: 10431051 .

Epplen JT. 1994. DNA fingerprinting. Simple repeat loci as tools for genetic identification. Ancient DNA: recovery and analysis of genetic materials from paleontological, archeological, museum, medical, and forensic specimens. New York: Springer Verlag. pp. 13-30.

Epplen JT, Mäueler, Santos EJM. 1998. On GATAGATA and other "junk" in the barren stretch of the genomic desert. Cytogeneics and Cellular Genetics. 80: 75-82.

Estoup A. 1993. (CT)n and (GT)n microsatellites: a new class of genetic markers for Salmo trutta L. (brown trout). Heredity. 71: 488-496.

Estoup A, Rousset F, Michalakis Y, Cornuet JM, Adriamanga M, Guyomard R. 1998b. Comparative analysis of microsatellite and allozyme markers: a case study investigating microgeographic differentiation in brown trout (Salmo trutta). Molecular Ecology. 7: 339-353.

Estoup A, Gharbi K, SanCristobal M, Chevalet C, Haffray P, Guyomard R. 1998a. Parentage assignment using microsatellites in turbot (Scophthalmus maximus) and rainbow trout (Oncorhynchus mykiss) hatchery populations. Canadian Journal of Fisheries and Aquatic Sciences. 55: 715-725.

Fan B, Wang ZG, Li YJ, Zhao KL, Liu B, Zhao SH, Yu M, Li MH, Chen SL, Ziong TA, Li K. 2002. Genetic variation analysis within and among Chinese indigenous swine populations using microsatellite markers. Animal Genetics. 33: 422-427.

Faundez V, Blanco G, Vazquez E, Sanchez JA. 1997. Allozyme variability in brown trout Salmo trutta in Chile. Freshwater Biology. 37: 507-514.

Favro LD, Kuo PK, McDonald JF. 1979. Population-genetic study of the effects of selective fishing on the growth rate of trout. Journal of the Fisheries Research Board of Canada. 36: 552-561.

Favro LD, Kuo PK, McDonald JF, Favro DD, Kuo AD. 1982. A multi-locus genetic model applied to the effects of selective fishing on the growth rate of trout. Canadian Journal of Fisheries and Aquatic Sciences. 39: 1540-1543. 
Ferguson A, Mason FM. 1981. Allozyme evidence for reproductively isolated sympatric populations of brown trout Salmo trutta L in Lough Melvin, Ireland. Journal of Fish Biology. 18: 629-642.

Ferguson A, Fleming CC. 1983. Evolutionary and taxonomic significance of protein variation in the brown trout (Salmo trutta L.) and other salmonid fishes. Systematics Association Special Volume 24: 85-99.

Ferguson A. 1995b. Molecular approaches to the study of genetic variation in salmonid fishes. Nordic Journal of Freshwater Research 71: 23-32 .

Ferguson A. 1995a. The application of molecular markers to the study and conservation of fish populations, with special reference to Salmo. Journal of Fish Biology. 47 (Suppl A): 103-126.

Ferguson MM, Danzmann RG, Allendorf FW. 1988a. Developmental success of hybrids between two taxa of salmonid fishes with moderate structural gene divergence. Canadian Journal of Zoology. 66: 1389-1395.

Ferguson MM, Knudsen KL, Danzmann RG, Allendorf FW. 1988 b. Developmental rate and viability of rainbow trout with a null allele at a lactate dehydrogenase locus. Biochemical Genetics. 26: 177-189.

Ferguson MM, Drahuschak LR. 1990. Disease resistance and enzyme heterozygosity in rainbow trout. Heredity. 64: 413-417.

Ferguson MM, Ihssen PE, Hynes JD. 1991. Are cultured stocks of brown trout (Salmo trutta) and rainbow trout (Oncorhynchus mykiss) genetically similar to their source populations? Canadian Journal of Fisheries and Aquatic Sciences. 48: $118-123$.

Ferguson MM, Danzmann RG, Arndt SKA. 1993. Mitochondrial DNA and allozyme variation in Ontario cultured rainbow trout spawning in different seasons. Aquaculture. 117: 237-259.

Ferguson MM, Danzmann RG. 1998. Role of genetic markers in fisheries and aquaculture: useful tools or stamp collecting? Canadian Journal of Fisheries and Aquatic Sciences. 55: 1553-1563.

Fessler JL. 1977. Adult returns from smolts originating from the matings of wild and hatchery summer steelhead. Journal of the Fisheries Research Board of Canada. 34: 56.

Fishback AG, Danzmann RG, Sakamoto T, Ferguson MM. 1999. Optimization of semi-automated microsatellite multiplex polymerase chain reaction systems for rainbow trout (Oncorhynchus mykiss). Aquaculture. 172: 247-254. 
Fishback AG, Danzmann RG, Ferguson MM. 2000. Microsatellite allelic heterogeneity among hatchery rainbow trout maturing in different seasons. Journal of Fish Biology. 57: 1367-1380.

Fishback AG, Danzmann RG, Ferguson MM, Gibson JP. 2002. Estimates of genetic parameters and genotype by environment interactions for growth traits of rainbow trout (Oncorhynchus mykiss) as inferred using molecular pedigrees. Aquaculture. 206: 137-150.

Fisher PW, Browne D, Cameron DG, Vyse ER. 1982. Genetics of rainbow trout in a geothermally heated stream. Transactions of the American Fisheries Society. 111: $312-316$.

Fjalestad KT, Moen T, Gomez-Raya L. 2003. Prospects for genetic technology in salmon breeding programmes. Aquaculture Research. 34: 397-406.

Foote CJ, Wood CC, Withler RE. 1989. Biochemical genetic comparison of sockeye salmon and kokanee, the anadromous and nonanadromous forms of Oncorhynchus nerka. Canadian Journal of Fisheries and Aquatic Sciences. 46: $149-158$

Fontaine PM, Dodson JJ. 1999. An analysis of the distribution of juvenile Atlantic salmon (Salmo salar) in nature as a function of relatedness using microsatellites. Molecular Ecology. 8: 189-198.

Forbes SH, Allendorf FW. 1991a. Associations between mitochondrial and nuclear genotypes in cutthroat trout hybrid swarms. Evolution. 45: 1332-1349.

Forbes SH, Allendorf FW. 1991b. Mitochondrial genotypes have no detectable phenotypic effects in cutthroat trout hybrid swarms. Evolution. 45: 1350-1359.

Forbes SH, Knudsen KL, Allendorf FW. 1994. Genetic variation in coho salmon detected by PCR amplification of growth hormone gene introns. NOAA Tech. Mem. NMFS-NWFSC-17: 29-33.

Franck JPC, Harris AS, Bentzen P, Denovan-Wright EM, Wright JM. 1991. Organization and evolution of satellite, minisatellite, and microsatellite DNAs in teleost fishes. Oxford Surveys on Eukaryotic Genes 7: 51-82.

Fritzner NG, Hansen MM, Madsen SS, Kristiansen K. 2001. Use of microsatellite markers for identification of indigenous brown trout in a geographical region heavily influenced by stocked domesticated trout. Journal of Fish Biology. 58: 1197-1210. 
Frose R, Pauly D. 2005. FishBase. World Wide Web electronic publication. www.fishbase.org, version (10/2005)

Funk WC, Tyburczy JA, Knudsen KL, Linder KR, Allendorf FW. 2005. Genetic basis of variation in morphological and life-history traits of a wild population of pink salmon. Journal of Heredity. 96: 24-31.

Gall GA. 1975. Genetics of reproduction in domesticated rainbow trout. Journal of Animal Science. 40: 19-28.

Gall GAE, Gross SJ. 1978. A genetic analysis of the performance of three rainbow trout broodstocks. Aquaculture. 15: 113-127.

Gall GA. 1981. Para-albumin polymorphism: an unlinked two-locus system in rainbow trout. Journal of Heredity. 72: 22-26.

Gall GA, Baltodano J, Huang N. 1988. Heritability of age at spawning for rainbow trout. Aquaculture. 68: 93-102.

Gall GA. 1993. Estimating genetic change from selection. Aquaculture. 111: 75-88.

Galvin P, McKinnell S, Taggart JB, Ferguson A, O'Farrell M, Cross TF. 1995. Genetic stock identification of Atlantic salmon using single locus minisatellite DNA profiles. Journal of Fish Biology. 47 (Suppl. A): 186-199.

Galvin P, Taggart J, FergusonA, O’Farrell M, Cross T. 1996. Population genetics of Atlantic salmon (Salmo salar) in the River Shannon system in Ireland: an appraisal using single locus minisatellite (VNTR) probes. Canadian Journal of Fisheries and Aquatic Sciences. 53: 1933-1942.

Garcia de Leaniz C, Verspoor E, Hawkins AD. 1989. Genetic determination of the contribution of stocked and wild atlantic salmon (Salmo salar) to the angling fisheries in two Spanish rivers. Journal of Fish Biology. 35 (Suppl. A): 261-270.

Garcia-Marin JL, Jorde PE, Ryman N, Utter F, Pla C. 1991. Management implications of genetic differentiation between native and hatchery populations of brown trout (Salmo trutta) in Spain. Aquaculture. 95: 235-249.

Garcia-Marin JL, Utter FM, Pla C. 1999. Postglacial colonization of brown trout in Europe based on distribution of allozyme variants. Heredity. 82: 46-56.

Garrison RL. 1977. Progress report on selective breeding experiments with winter steelhead on the Alsea river and their management implications In: Hassler TJ, VanKirk RR, editors. Genetic Implications of Steelhead Management. California Coop. Fish. Res. Unit Spec. Rep. 77-1: 43. 
Gharbi K, Semple JW, Ferguson MM, Schulte PM, Danzmann RG. 2004.

Linkage arrangement of $\mathrm{Na}, \mathrm{K}$-ATPase genes in the tetraploid-derived genome of the rainbow trout (Oncorhynchus mykiss). Animal Genetics. 35: 321-325.

Gharrett AJ, Shirley SM. 1985. A genetic examination of spawning methodology in a salmon hatchery. Aquaculture. 47: 245-256.

Gilbey J, Verspoor E, McLayA, Houlihan D. 2003. A microsatellite linkage map for Atlantic salmon (Salmo salar). Animal Genetics. 35: 98-105.

Gilbey J, Verspoor E, McLay A, Houlihan D. 2004. A microsatellite linkage map for Atlantic salmon (Salmo salar). Animal Genetics. 35: 98-105.

Gilbey J, McLay A, Houlihan D, Verspoor E. 2005. Individual-level analysis of pre- and post first-feed growth and development in Atlantic salmon. Journal of Fish Biology. 67: 1359-1369.

Gile SR, Ferguson MM. 1990. Crossing methodology and genotypic diversity in a hatchery strain of rainbow trout (Oncorhynchus mykiss). Canadian Journal of Fisheries and Aquatic Sciences. 47: 719-724.

Giuffra E, Guyomard R, Forneris G. 1996. Phylogenic relationships and introgression patterns between incipient parapatric species of Italian brown trout (Salmo trutta L. complex). Molecular Ecology. 5: 207-220.

Gjedrem T, Aulstad D. 1974. selection experiments with salmon. 1. Differences in resistance to vibrio disease of salmon parr (Salmo salar). Aquaculture. 3: 5159.

Gjedrem T. 1976. Possibilities for genetic improvements in salmonids. Journal of the Fisheries Research Board of Canada. 33: 1094-1099.

Gjedrem T. 1983. Genetic variation in quantitative traits and selective breeding in fish and shellfish. Aquaculture. 33: 51-72.

Gjedrem T. 1991. Genetic variation in susceptibility of Atlantic salmon to furunculosis. Aquaculture. 97: 1-6.

Gjedrem T. 1997. Flesh quality improvement in fish through breeding. Aquaculture International. 5: 197-206.

Gjedrem T. 2000. Genetic improvement of cold-water fish species. Aquaculture Research. 31: 25-33. 
Gjerde B. 1983. Effects of inbreeding on survival and growth in rainbow trout. Aquaculture. 34: 327-332.

Gjerde B. 1984. Estimates of phenotypic and genetic parameters for carcass traits in Atlantic salmon and rainbow trout. Aquaculture. 36: 97-110.

Gregg RE, Rhodes OE, Armstrong G. 2001. A genetic analysis of the London strain of rainbow trout. Animal Genetics. 32: 210-214.

Grewe PM, Krueger CC, MarsdenJE, Aquadro CF, May b. 1994. Hatchery origins of naturally produced lake trout fry captured in Lake Ontario: temporal and spatial variability based on allozyme and mitochondrial DNA data. Transactions of the American Fisheries Society. 123: 309-320.

Guglich EA, Wilson PJ, White BN. 1993. Application of DNA fingerprinting to enforcement of hunting regulations in Ontario. Journal of Forensic Sciences. 38: 48-59.

Guglich EA, Wilson PJ, White BN. 1994. Forensic application of repetitive DNA markers to the species identification of animal tissues. Journal of Forensic Sciences. 39: 353-361.

Gunnes K, Gjedrem T. 1976. Genetic variation in growth and meat quality traits in rainbow trout.

Gunnes K. 1981. A genetic analysis of body weight and length in rainbow trout reared in seawater for 18 months. Aquaculture. 24: 161-174.

Guyomard R. 1981. Electrophoretic variation in four French populations of domesticated rainbow trout (Salmo gairdneri). Canadian Journal of Genetics and Cytology. 23: 33-47.

Guyomard R, Kreig F. 1983. Electrophoretic variation in six populations of brown trout (Salmo trutta L.). Canadian Journal of Genetics and Cytology. 25: 403-413.

Gyllensten U, Leary RF, Allendorf FW, Wilson AC. 1985. Introgression between two cutthroat trout subspecies with substantial karyotypic, nuclear, and mitochondrial genomic divergence. Genetics. 111: 905-915.

Gyllensten U, Wilson AC. 1987. Mitochondrial DNA of salmonids. In: population genetics and fishery management. Ryman N, Utter F, eds. pp. 301317. University of Washington Press,Seattle, WA. 
Hamilton KE, Ferguson A, Taggart JB, Tomason T, Walker A, Fahy E. 1989. Post-glacial colonization of brown trout, Salmo trutta L.: Ldh-5 as a phylogeographic marker locus. Journal of Fish Biology. 35: 651-664.

Hansen JD, Landis ED, Phillips RB. 2005. Discovery of a unique Ig heavy-chain isotype (IgT) in rainbow trout: Implications for a distinctive B cell developmental pathway in teleost fish. Proceedings of the National Academy of Sciences, U.S. A. 102: 6919-6924.

Hansen MM, Loeschcke V. 1996. Genetic differentiation among Danish brown trout populations, as detected by RFLP analysis of $\mathrm{PCr}$ amplified mitochondrial DNA segments. Journal of Fish Biology. 48: 422-436.

Hansen MM, Mensberg KLD. 1998. Genetic differentiation and relationship between genetic and geographical distance in Danish sea trout (Salmo trutta L.) populations. Heredity. 81: 493-504.

Hansen MM. 2002. Estimating the long-term effects of stocking domesticated trout into wild brown trout (Salmo trutta) populations: an approach using microsatellite DNA analysis of historical and contemporary samples. Molecular Ecology. 11: 1003-1015.

Hartley SE, McGowan C, Greer RB, Walker AF. 1992. The genetics of sympatric Arctic charr [Salvelinus alpinus (L.)] populations from Loch Rannoch, Scotland. Journal of Fish Biology. 41: 1021-1031.

Heath DD, Busch C, Kelly J, Atagi DY. 2002. Temporal change in genetic structure and effective population size in steelhead trout (Oncorhynchus mykiss). Molecular Ecology. 11: 197-214.

Hedrick P, Miller PS. 1992. Conservation genetics: techniques and fundamentals. Ecological Applications. 2: 30-46.

Hedrick PW. 1999. Perspective: highly variable genetic loci and their interpretation in evolution and conservation. Evolution. 53: 313-318.

Hendry AP, Quinn TP, Utter FM. 1996. Genetic evidence for the persistence and divergence of native and introduced sockeye salmon (Oncorhynchus nerka) within Lake Washington, Washington. Canadian Journal of Fisheries and Aquatic Sciences. 53: 823-832.

Herbinger CM, Doyle RW, Pitman ER, Paquet D, Mesa KA, Morris DB, Wright JM, Cook D. 1995. DNA fingerprint passed analysis of paternal and maternal effects on offspring growth and survival in communally reared rainbow trout. Aquaculture. 137: 245-256. 
Hershbergr WK. 1990. Genetic changes in the growth of coho salmon (Oncorhynchus kisutch) in marine net-pens, produced by ten years of selection. Aquaculture. 84: 187-197.

Hershberger WK. 1992. Genetic variability in rainbow trout populations. Aquaculture. 100: 51-71.

Hitt NP, Frissell CA, Muhlfeld C, Allendorf FW. 2003. Spread of hybridization between native westslope cutthroat trout, Oncorhynchus mykiss lewisi, and nonnative rainbow trout, O. mykiss. Canadian Journal of Fisheries and Aquatic Sciences. 60: 1440-1451.

Holm LE, Brusgaard K. 1999. Two polymorphic dinucleotide repeats in rainbow trout (Oncorhynchus mykiss). Animal Genetics. 30: 162-163.

Holm LE, Loeschcke V, Bendixen C. 2001. Elucidation of the molecular basis of a null allele in a rainbow trout microsatellite. Marine Biotechnology. 3: 555560 .

Hudzyk L, Tsuyuki H. 1974. Distribution of LDH-"B" gene in resident and anadromous rainbow trout (Salmo gairdneri) from streams in British Columbia. Journal of the Fisheries Research Board of Canada. 31: 106-108.

Hurrell RH, Price DJ. 1993. Genetic variation in Atlantic salmon, Salmo salar L., within the Tamar catchment in south-west England. Journal of Fish Biology. 42: $153-156$.

Hynes JD, Brown EH, Helle JH, Ryman NR, Webster DA. 1981. Guidelines for the culture of fish stocks for resource management. Canadian Journal of Fisheries and Aquatic Sciences. 38: 1867-1876.

Hynes RA, Ferguson A, McCann MA. 1996. Variation in mitochondrial DNA and the pattern of post-glacial colonization in north-west European populations of brown trout (Salmo trutta L.). Journal of Fish Biology. 48: 54-67.

Ibarra AM. 1994. Genetic analysis of rainbow trout susceptibility to the myxosporean, Ceratomyxa Shasta. Aquaculture. 120: 239-262.

Ihssen PE, Casselman JM, Martin GW, Phillips RB. 1988. Biochemical genetic differentiation of lake trout (Salvelinus namaycush) stocks of the Great Lakes Region. Canadian Journal of Fisheries and Aquatic Sciences. 45: 1018-1029.

Ishikawa A, Sakamoto T, Okamato N, Ikeda Y. 1996. Variable number of tandem repeat marker, RVF9405, in rainbow trout. Journal of Animal Science. 74: 1737. 
Jackson TR, Ferguson MM, Danzmann RG, Fishback AG, Ihssen PE, O'Connell M, Crease TJ. 1998. Identification of two QTL influencing upper temperature tolerance in rainbow trout. Heredity. 80: 143-151.

Jeffreys AJ. 1985. Hypervariable 'minisatellite' regions in human DNA. Nature. 314: $67-73$.

Jonasson J. 1997. Genetic correlation for body weight of Atlantic salmon grilse between fish in sea ranching and land-based farming. Aquaculture. 157: 205214.

Johnson KR. 1987. Linkage relationships reflecting ancestral tetraploidy in salmonid fish. Genetics. 116, 579-91

Johnson, OW, Waples RS, Wainwright TC, Neely KG, Waknitz FW, Parker LT. 1994. Status review for Oregon's Umpqua River Sea-Run Cutthroad Trout. NOAA Technical Memorandum NMFS-NWFSC-15. National marine Fisheries Service, Northwest Fisheries Science Center, Seattle, WA.

Jordan WC, Youngson AF. 1992. The use of genetic marking to assess the reproductive success of mature male Atlantic salmon parr (Salmo salar L.) under natural spawning conditions. Journal of Fish Biology. 41: 613-618.

Jordan WC, Youngson AF, Hay DW, Fertuson A. 1992. Genetic protein variation in natural populations of Atlantic salmon (Salmo salar) in Scotland: temporal and spatial variation. Canadian Journal of Fisheries and Aquatic Sciences. 49: 1863-1872.

Jordan WC, Verspoor E, Youngson AF. 1997. The effect of natural selection on estimates of genetic divergence among populations of the Atlantic salmon. Journal of Fish Biology. 51: 546-560

Jordan WC, Cross TF, Crozier WW, Ferguson A, Galvin P, Hurrell RH, McGinnity P, Martin SAM, Moffett IJJ, Price DJ, Youngson AF, Verspoor E. 2005. Allozyme variation in Atlantic salmon from the British Isles: associations with geography and the environment. Journal of Fish Biology. 67 (Suppl. A): 146-168.

Jug T, Berrebi P, Snoj A. 2005. Distribution of non-native trout in Solvenia and their introgression with native populations as observed through microsatellite DNA analysis. Biological Conservation. 123: 381-388.

Kalinowski ST. 2002. How many alleles per locus should be used to estimate genetic distances? Heredity. 88: 62-65. 
Kanda N, Allendorf FW. 2001. Genetic population structure of bull trout from the Flathead River basin as shown by microsatellites and mitochondrial DNA markers. Transactions of the American Fisheries Society. 130: 92-106.

Kanda N, Leary RF, Allendorf FW. 2002b. Evidence of introgressive hybridization between bull trout and brook trout. Transactions of the American Fisheries Society. 131: 772-782.

Kanda N. 2002a. Molecular genetic markers identifying hybridization between the Colorado River-Greenback cutthroat trout complex and yellowstone cutthroat trout or rainbow trout. Transactions of the American Fisheries Society. 131: 312319.

Katoh MM. 2005. Identification and characterization of human HESL, rat Hesl and rainbow trout hesl genes in silico. International Journal of Molecular Medicine. 14: 747-751.

Kause A, Ritola O, Paananen T. 2004. Breeding for improved appearance of large rainbow trout in two production environments. Aquaculture Research. 35: 924-930.

Kendall WC. 1920. What are rainbow trout and steelhead trout? Trans. Am. Fish. Soc. 50: 187-199

Khatkar MS, Thomson PC, Tammen I, Paadsma HW. 2004. Quantitative trait loci mapping in dairy cattle: review and meta-analysis. Genetics, Selection, Evolution. 36: 163-190.

Khoo SK, Ozaki A, Sakamoto T, Okamoto N. 2000. Four highly polymorphic dinucleotide microsatellites in rainbow trout (Oncorhynchus mykiss). Animal Genetics. 31: 73-74.

Khoo SK, Ozaki A, Sakamoto T, Okamoto N. 2000. Two highly polymorphic dinucleotide microsatellites in rainbow trout (Oncorhynchus mykiss): OmyRGT18TUF and OmyRGT23TUF. Journal of Animal Science. 78: 490491.

Khoo SK, Ozaki A, Nakamura F, Arakawa T, Ishimoto S, Nickolov R, Sakamoto T, Akutsu T, Mochizuki M, Denda I, Okamoto N. 2004. Identification of a novel chromosomal region associated with infectious haematopoietic necrosis factor (IHN) resistance in rainbow trout Oncorhynchus mykiss. Gyobyo Kenkyu (Fish Pathology). 39: 95-101.

Kim JT, Parker KM, Hedrick PW. 1999. MHC differentiation in Sacramento River chinook salmon. Genetics. 151: 1115-1122. 
Kincaid HL, Mengel LJ, Brimm S. 2002. National fish strain registry - Trout. (NFSR-T): Species tables of reported strains and broodstocks. U.S. Fish and Wildlife Service and U.S. Geological Survey. Springfield, Virginia.

Kinnunen RE. 2000. A White Paper on the Status and Needs of Salmonid Aquaculture in the North Central Region. North Central Regional Aquaculture Center. http://ag.ansc.purdue.edu/aquanic/ncrac/wpapers/salmonid32900.pdf

Kinunen W, Moring JR. 1978. Origin and use of rainbow trout brood stocks. Progressive Fish Culturist. 40: 87-89.

King TL, Spidle AP, Eackles MS, Lubinski BA, Schill WB. 2000. Mitochondrial DNA diversity in North American and European Atlantic salmon with emphasis on the Downeast rivers of Maine. Journal of Fish Biology. 57: 614-630.

Klupp R, Heil G, Pirchner F. 1978. Effects of interaction between strains and environment on growth traits in rainbow trout (Salmo gairdneri). Aquaculture. 14: $271-275$.

Koljonen JL, McKinnell S. 1996. Assessing seasonal changes in stock composition of Atlantic salmon catches in the Baltic Sea with genetic stock identification. Journal of Fish Biology. 49: 998-1018.

Koljonen M, Tahtinen J, Saisa M, Koskiniemi J. 2002. Maintenance of genetic diversity of Atlantic salmon (Salmo salar) by captive breeding programmes and the geographic distribution of microsatellite variation. Aquaculture212: 69-92.

Kolstad K. 2005. Genetic variation in resistance of Atlantic salmon (Salmo salar) to the salmon louse Lepeophtheirus salmonis. Aquaculture. 247: 145-151.

Kono T, Sakai M, LaPatra SE. 2000. Expressed sequence tag analysis and gill tissues from rainbow trout (Oncorhynchus mykiss) infected with infectious hematopoietic necrosis virus. Marine Biotechnology. 2: 493 - 498

Krasnov A, Koskinen H, Afanasyev S, Molsa H. 2005. Transcripted Tc1-like transposons in salmonid fish. BMC Genomics. 6: 107.

Kreig F, Guyomard R. 1985. Population genetics of French brown trout Salmo trutta L.: large geographical differentiation of wild populations and high similarity of domesticated stocks. Genetique, Selection, Evolution. 17: 255-242.

Krueger CC, May B. 1987a. Stock identification of naturalized brown trout in Lake Superior tributaries: differentiation based on allozyme data. Transactions of the American Fisheries Society. 116: 785-794. 
Krueger CC, May B. $1987 \mathrm{~b}$ Genetic comparison of naturalized rainbow trout populations among Lake Superior tributaries: differentiation based on allozyme data. Transactions of the American Fisheries Society 116: 795-806.

Krueger CC, May B. 1991. Ecological and genetic effects of salmonid introductions in North America. Canadian Journal of Fisheries and Aquatic Sciences. 48 (Suppl 1): 66-77.

Lande R, Thompson R. 1989. Efficiency of marker-assisted selection in the improvement of quantitative traits. Genetics. 124: 743-756.

Landry C, Bernatchez L. 2001. Comparative analysis of population structure across environments and geographical scales at major histocompatability complex and microsatellite loci in Atlantic salmon (Salmo salar). Molecular Ecology. 10: 2525-2539.

LaPatra SE, Lauda KA, Jones GR, Shewmaker WD, Groff JM, Routledge D. 1996. Susceptibility and humoral response of brown trout $\mathrm{x}$ lake trout hybrids to infectious hematopoietic necrosis virus: a model for examining disease resistance mechanisms. Aquaculture. 146: 179-188.

Largiader CR, Scholl A. 1996. Genetic introgression between native and introduced brown trout Salmo trutta L. populations in the Rhone River Basin. Molecular Ecology. 5: 417-426.

Leary RF, Allendorf FW, Knudsen KL. 1983. Developmental stability and enzyme heterozygosity n rainbow trout. Nature. 301: 71-72.

Leary RF, Allendorf FW, Knudsen KL. 1984. Superior developmental stability of enzyme heterozygotes in salmonid fishes. American Naturalist. 124: 540551 .

Leary RF, Allendorf FW, Knudsen KL, Thorgaard GH. 1985a. Heterozygosity and developmental stability in gynogenetic diploid and triploid rainbow trout. Heredity. 54: 219-225.

Leary RF, Allendorf FW, Knudsen KL. 1985b. Developmental instability as an indicator of reduced genetic variation in hatchery trout. Transactions of the American Fisheries Society. 114: 230-235.

Leary RF, Allendorf FW, Phelps SR, Knudsen KL. 1987a. Genetic divergence and identification of seven subspecies of cutthroat trout and rainbow trout. Transactions of the American Fisheries Society. 116: 580-587. 
Leary RF, Allendorf FW, Knudsen KL. 1987b. Differences in inbreeding coefficients do not explain the association between heterozygosity at isozyme loci and developmental stability in rainbow trout. Evolution. 41: 1413-1415.

Leary RF, Allendorf FW, Knudsen KL. 1989. Genetic differences among rainbow trout spawned on different days within a single season. Progressive Fish Culturist.. 51: 10-19.

Leary RF, Allendorf FW, Forbes SH. 1993a. Conservation genetics of bull trout in the Columbia and Klamath River drainages. Conservation Biology. 7: 856865 .

Leary RF, Allendorf FW. 1997. Genetic confirmation of sympatric bull trout and Dolly Varden in western Washington. Transactions of the American Fisheries Society. 126: 715-720.

Leder EH, Danzmann RG, Ferguson MM. 2004. Comparison of GNRH3 genes across salmonid genera. Animal Genetics. 35: 126-129.

Leider SA, Chilcote MW, Loch JJ. 1986. Comparative life history characteristics of hatchery and wild steelhead trout (Salmo gairdneri) of summer and winter races in the Kalama River, Washington. Canadian Journal of Fisheries and Aquatic Sciences. 43: 1398-1409.

Leider SA, Hulett PL, Loch JJ, Chilcote MW. 1990. Electrophoretic comparison of the reproductive success of naturally spawning transplanted and wild steelhead trout through the returning adult stage. Aquaculture. 88: 239-252.

Liang KJ, Seacombes CJ. 2004. Trout CC chemokines: comparison of their sequences and expression patterns. Molecular Immunology. 41: 793-808.

Linder KR, Seeb JE, Habicht C, Kretschmer E, Reedy DJ, Spruell P, Allendorf FW. 2000. gene-centromere mapping of 312 marker loci in pink salmon by halftetrad analysis. Genome. 43: 538-549.

Liu Z, Cordes JF. 2004. DNA Marker Technologies and Their Applications in Aquaculture Genetics. Aquaculture 238: 1-37.

Loudenslager EJ, Thorgaard GH. 1979. Karyotypic and evolutionary relationships of Yellowstone (Salmo clarki bouvieri) and west-slope (S. c. lewisi) cutthroat trout. Journal of the Fisheries Research Board of Canada 36: 630-635.

Lund T. 1995. Genetic variation in immune parameters and associations to survival in Atlantic salmon. Journal of Fish Biology. 46: 748-758. 
Lundrigan TA, Reist JD, Ferguson MM. 2005. Microsatellite genetic variation within and among Arctic charr (Salvelinus alpinus) from aquaculture and natural populations in North America. Aquaculture. 244: 63-75.

Lynch JC, Vyse ER. 1979. Genetic variability and divergence in grayling (Thymallus articus). Genetics. 92: 263-278.

Lynch M. 1995. Inbreeding depression and outbreeding depression. In: Genetic effects of straying of non-native hatchery fish into natural populations. NOAA Tech Memo NMFS NWFSC-30.

MacCrimmon HR. 1971. World distribution of rainbow trout (Salmo gairdneri). Journal of the Fisheries Research Board of Canada. 28: 663-704.

Marnell LF, Behnke RJ, Allendorf FW. 1987. Genetic identification of the cutthroat trout (Salmo clarki) in Glacier National Park, Montana. Canadian Journal of Fisheries and Aquatic Sciences. 44: 1830-1839.

Marshall AR, Knudsen KL, Allendorf FW. 2004. Linkage disequilibrium between the pseudoautosomal PEPB-1 locus and the sex-determining region of chinook salmon. Heredity. 93: 85-97.

Martinez P, Arias J, Castro J, Sanchez L. 1993. Differential stocking incidence in brown trout (Salmo trutta) populations from Northwestern Spain. Aquaculture. 114: $203-216$.

Martyniuk CJ, Perry GML, Mogahadam HK, Ferguson MM, Danzmann RG. 2003. The genetic architecture of correlations among growth-related traits and male age at maturation in rainbow trout. Journal of Fish Biology. 63: 746-764.

Matsuoka MP, Gharrett AJ, Wilmot RL, Smoker WW. 2004 Genetic Linkage Mapping of Allozyme Loci in Even- and Odd-year Pink Salmon (Oncorhynchus gorbuscha). Journal of Heredity. 95: 421-429.

May B, Stoneking M, Wright JE. 1979a. Joint segregation of malate dehydrogenase and diaphorase loci in brown trout (Salmo trutta). Transactions of the American Fisheries Society 108: 373-377.

May B, Wright JE, Stoneking M. 1979b. Joint segregation of biochemical loci in Salmonidae: Results from experiments with Salvelinus and review of the literature on other species. Journal of the Fisheries Research Board of Canada. 36: $1114-1128$.

May B, Stoneking M, Wright JE. 1980. Joint segregation of biochemical loci in Salmonidae. II. Linkage associations from a hybridized Salvelinus genome (S. namaycush x S. fontinalis). Genetics. 95: 707-726. 
May B, Wright JE, Johnson KR. 1982. Joint segregation of biochemical loci in Salmonidae. II. Linkage associations in Salmonidae including data from rainbow trout (Salmo gairdneri). Biochemical Genetics. 20: 29-40.

Mazurais D, Montfort J, Delalande C, LeGac F. 2005. Transcriptional analysis of testis maturation using trout cDNA macroarrays. General and Comparative Endocrinology. 142: 143-154.

McAndrew BJ, Penman DJ, Frank-Lawale A, Brown C, Schmidt JU, Herlin M. 2004. Applying genetics in aquaculture. Fish Farmer. 27: 10-13.

McConnell SKJ, O’Reilly P, Hamilton L, Wright JM, Bentzen P. 1995a. Polymorphic microsatellite loci from Atlantic salmon (Salmo salar): genetic differentiation of North American and European populations. Canadian Journal of Fisheries and Aquatic Sciences. 52: 1863-1872.

McConnell SK, Hamilton L, Morris D, Cook D, Paquet D, Bentzen P, Wright JM. 1995b. Isolation of salmonid microsatellite loci and their application to population genetics of Canadian east coast stocks of Atlantic salmon. Aquaculture. 137: 1930 .

McDonald D. 2004. Population Genetics IV: Genetic distances -- biological vs. geometric approaches. World Wide Web document. http://www.uwyo.edu/dbmcd/molmark/lect06/lect6.html [Accessed June 2006]

McDonald GJ, Ferguson MM, Danzmann RG. 2004. Relatedness determination in the absence of pedigree information in three cultured strains of rainbow trout (Oncorhynchus mykiss). Aquaculture. 233: 65-78.

McElligott EA, Cross TF. 1991. Protein variation in wild Atlantic salmon, with particular reference to sourthern Ireland. Journal of Fish Biology. 39: (suppl. A). $35-42$.

McElhany P, Ruckelshaus MH, Ford MJ, Wainwright TC, Bjorkstedt EP. 2000. Viable salmonid populations and the recovery of evolutionary significant units. U. S. Dept. Commer, NOAA Technical Memorandum NMFS-NWFSC-42. National marine Fisheries Service, Northwest Fisheries Science Center, Seattle, WA.

McGinnity P, Prodohl P, Maoileidigh O, Hynes R, Cotter D, Baker N, O’Hea B, Ferguson A. 2004. Differential lifetime success and performance of native and non-native Atlantic salmon examined under communal natural conditions. Journal of Fish Biology. 65 (suppl. A): 173-187. 
McGowan CR, Davidson EA, Woram RA, Danzmann RG, Ferguson MM, Davidson WS. Ten polymorphic microsatellite markers from Arctic charr (Salvelinus alpinus): linkage analysis and amplification in other salmonids. Animal Genetics. 35: 462-504.

McKay SJ, Devlin RH, Smith MJ. 1996. Phylogeny of Pacific salmon and trout based on growth hormone type 2 and mitochondrial NADH dehydrogenase subunit 3 DNA sequences. Canadian journal of Fisheries and Aquatic Sciences. 53: $1165-1176$

McKay SJ, Trautner J, Smith MJ, Koop BF, Devlin RH. 2004. Evolution of duplicated growth hormone genes in autotetraploid salmonid fishes. Genome. 47: 714-723.

McLean JE, Bentzen P, Quinn TP. 2003. Differential reproductive success of sympatric, naturally spawning hatchery and wild steelhead trout (Oncorhynchus mykiss) through the adult stage. Canadian Journal of Fisheries and Aquatic Sciences. 60: 433-440.

McLean JE, Bentzen P, Quinn TP. 2004. Differential reproductive success of sympatric, naturally spawning hatchery and wild steelhead (Oncorhynchus mykiss). Environmental Biology of Fishes. 69: 359-369.

McMeel OM, Hoey EM, Ferguson A. 2001. Partial nucleotide sequences, and routine typing by polymerase chain reaction-restriction fragment length polymorphism of the brown trout (Salmo trutta) lactate dehydrogenase, LDHC1*90 and *100 alleles. Molecular Ecology. 10: 29-34.

McVeigh HP, Davidson WP. 1991. A salmonid phylogeny inferred from mitochondrial cytochrome b gene sequences. Journal of Fish Biology. (Suppl. A): $277-282$.

McVeigh HP. 1995. Mitochondrial DNA differentiation of sympatric populations of brown trout, Salmo trutta L., from Lough Melvin, Ireland. Canadian Journal of Fisheries and Aquatic Sciences. 52: 1617-1622.

Millenbach C. 1973. Genetic selection of steelhead for management purposes. In Smith MW, carter WM, editors. The International Atlantic Salmon Foundation, Special Publication Series. 4: 253-257.

Miller KM, Withler RE, Beacham TD. 1996. Stock identification of coho salmon (Oncorhynchus kisutch) using minisatellite DNA variation. Canadian Journal of Fisheries and Aquatic Sciences. 53: 181-195. 
Milner GB. 1977. Biochemical variation: Its use in mixed fishery analysis. Proceedings of the Genetic Implications of Steelhead Management Symposium, 20-21 May 1977. Calif. Coop. Fish. Res. Unit, Spec. Rep. 77-1.

Milner GB, Teel DJ, Utter FM. 1979. Electrophoretic survey of protein variation in eight strains of rainbow trout (Salmo gairdneri) from the U.S. Fish and Wildlife Service Genetics Laboratory. Report of Research (FY 79) to the U.S. Fish and Wildlife Service, Cooperative Agrteement No. 14-16-0009-79-911.

Milner et al., 1980. Columbia River stock identification study. NOAA National Marine Fisheries Service. Final Report of Research, FY 1979.

Molony BW, Maguire GB, Church AR. 2004. A comparison of the heat tolerance and growth of a selected and non-selected line of rainbow trout, (Oncorhynchus mykiss), in Western Australia. Aquaculture. 214: 655-665.

Moody DE. 2001. Genomics techniques: an overview of methods for the study of gene expression. Journal of Animal Science. 79 (E. Suppl.): E128-E135.

Moran P. Pendas AM, Garcia-Vazquez E, Izquierdo J. 1991. Failure of a stocking policy of hatchery reared brown trout, Salmo trutta L., in Asturias, Spain, detected using LDH-5* as a genetic marker. Journal of Fish Biology. 39: (suppl A): 117-121.

Moran P, Pendas AM, Garcia-Vazquez E, Izquierdo JI. 1994a. Genetic variation among Atlantic salmon in six Spanish rivers. Journal of Fish Biology.: 45: 831837.

Moran P, Pendas AM, Garcia-Vazquez E, Izquierdo JI, Rutherford T. $1994 \mathrm{~b}$. Electrophoresis assessment of the contribution of transplanted Scottish Atlantic salmon (Salmo salar) to the Esva river (Northern Spain). Canadian Journal of Fisheries and Aquatic Sciences. 51: 248-252.

Moran P, Pendas AM, Garcia-Vasquez E, Izquierdo JI, Lobon-Cervia J. 1995. Estimates of gene flow among neighbouring populations of brown trout. Journal of Fish Biology. 46: 593-602.

Moran P, Perez J, Dumas J, Beall E, Garcia-Vazquez E. 2005. Stocking-related patterns of genetic variation at enzymatic loci in south European Atlantic salmon populations. Journal of Fish Biology. 67 (suppl. A): 185-199.

Morris DB, Richard KR, Wright JM. 1996. Microsatellites from rainbow trout (Oncorhynchus mykiss) and their use for genetic study of salmonids. Canadian Journal of Fisheries and Aquatic Sciences. 53: 120-126. 
Murata S, Gakasaki N, Saitoh M, Okada N. 1993. Determination of the phylogenetic relationships among Pacific salmonids by using short interspersed elements (SINEs) as temporal landmarks of evolution. Proceedings of the National Academy of Sciences, USA. 90L: 6995-6999.

National Agricultural Statistics Service. 2005. Trout Production. Agricultural Statistics Board, U.S. Dept. of Agriculture. Publ. Aq 2. www.usda.gove/nass

Nakamura K, Ozaki A, Akutsu T, Iwai K, Sakamoto T, Yoshizaki G, Okamoto N. 2001. Genetic mapping of the dominant albino locus in rainbow trout (Oncorhynchus mykiss). Molecular Genetics and Genomics. 265: 687-693.

Narum SR, Contor C, Talbot A, Powell MS. 2004. Genetic divergence of sympatric resident and anadromous forms of Oncorhynchus mykiss in the Walla Wall River, U. S. A. Journal of Fish Biology. 65: 471-488.

NatureServe. 2006. NatureServe Explorer: An online encyclopedia of life [web application]. Version 4.7. NatureServe, Arlington, Virginia. Available http://www.natureserve.org/explorer. (Accessed: June, 2006 ). http://www.natureserve.org/explorer/servlet/NatureServe?searchName=ONCORH $\underline{\text { YNCHUS+MYKISS }}$

Nelson RJ, Beacham TD. 1999. Isolation and cross species amplification of microsatellite loci useful for study of pacific salmon. Animal Genetics. 30: 228229.

Nichols KM, Bartholomew J, Thorgaard GH. 2003. Mapping multiple genetic loci associated with Ceratomyxa shasta resistance in Oncorhynchus mykiss. Diseases of Aquatic Organisms. 56: 145-154.

Nichols KM, Young WP, Danzmann RG, Robison BD, Rexroad C, Noakes M, Phillips RB, Bentzen P, Spies I, Knudsen K, Allendorf FW, Cummingham BM, Brunelli J, Zhang H, Ristow S, Drew R, Brown KH, Wheeler PA, Thorgaard GH. 2003. A consolidated linkage map for rainbow trout (Oncorhynchus mykiss). Animal Genetics. 34: 102-115.

Nielsen EE, Hansen MM, Loeschcke V. 1997. Analysis of microsatellite DNA from old scale samples of Atlantic salmon (Salmo salar) using microsatellites. Animal Genetics. 29: 363-370.

Nielsen EE, Hansen MM, Loescheke V. 1999. Genetic variation in time and space: microsatellite analysis of extinct and extant populations of Atlantic salmon. Evolution. 53: 261-268. 
Nielson JL, Tupper D, Thomas WK. 1994. Mitochondrial DNA polymorphism in unique runs of chinook salmon (Oncorhynchus tshawytscha) from the Sacramento-San Joaquin River basin. Conservation Biology. 8: 882-884.

Nielsen JL, Crow KD, Fountain MC. 1999. Microsatellite diversity and conservation of a relic trout population: McCloud River redband trout. Molecular Ecology. 8: S129-S142.

Norris AT, Bradley DG, Cunningham EP. 1999. Microsatellite genetic variation between and within farmed and wild Atlantic salmon (Salmo salar) populations. Aquaculture. 180: 247-264.

Norris AT, Bradley DG, Cunningham EP. 2000. Parentage and relatedness determination in farmed Atlantic salmon (Salmo salar) using microsatellite markers. Aquaculture. 182: 73-83.

Northcote TG, Williscroft SN, Tsuyuki H. 1970. Meristic and lactate dehydrogenase genotype differences in stream populations of rainbow trout below and above a waterfall. Journal of the Fisheries Research Board of Canada. 27: 1987-1995.

O’Connell M, Danzmann RG, Cornuet J, Wright JM, Ferguson MM. 1997. Differentiation of rainbow trout (Oncorhynchus mykiss) populations in Lake Ontario and the evaluation of the stepwise mutation and infinite allele mutation models using microsatellite variability. Canadian Journal of Fisheries and Aquatic Sciences. 54: 1391-1399.

Okubo K, Hori N, Matoba R, Niiyama T, Fukushima A, Kojima Y, Matsubara K. 1992. Large scale cDNA sequencing for analysis of quantitative and qualitative aspects of gene expression. Nature Genetics. 2: 173-9

O’Malley KG, Sakamoto T, Danzmann RG, Ferguson MM. 2002. Quantitative trait loci for spawning date and body weight in rainbow trout: testing for conserved effects across ancestrally duplicated chromosomes. Journal of Heredity. 94: 273-284.

O’Reilly PT, Herbinger C, Wright JM. 1998. Analysis of parentage determination in Atlantic salmon (Salmo salar) using microsatellites. Animal Genetics. 29: 363-370.

Ostberg CO, Rodriguez RJ. 2002. Novel molecular markers differentiate Oncorhynchus mykiss (rainbow trout and steelhead) and the O. clarkia (cutthroat trout) subspecies. Molecular Ecology Notes. 2: 197-202.

O’Connell M, Danzmann RG, Cornuet JM, Wright JM, Ferguson MM. 1997. Differentiation of rainbow trout populations in Lake Ontario and the evaluation of the stepwise mutation and infinite allele mutation models using microsatellite 
variability. Canadian Journal of Fisheries and Aquatic Sciences. 54: 13911399.

Okazaki T. 1984. Genetic divergence and its zoogeographic implications in closely related species Salmo gairdneri and Salmo mykiss. Japanese Journal of Ichthyology. 31: 297-309.

Olsen JB, Seeb LW, Bentzen P, Seeb J. 1998. Genetic interpretation of broadscale microsatellite polymorphism in odd-year pink salmon. Transactions of the American Fisheries Society. 127: 535-350

O’Malley KG, Sakamot T, Danzmann RG, Ferguson MM. 2002. Quantitative trait loci for spawning date and body weight in rainbow trout: testing for conserved effects across ancestrally duplicated chromosomes. Journal of Heredity. 94: 273-284.

O'Reilly PT, Hamilton LC, McConnell SK, Wright JM. 1996. Rapid analysis of genetic variation in Atlantic salmon (Salmo salar) by PCR multiplexing of dinucleotide and tetranucleotide microsatellites. Canadian Journal of Fisheries and Aquatic Sciences. 53: 2292-2298.

O’Reilly PT, Herbinger C, Wright JM. 1998. Analysis of parentage determination in Atlantic salmon (Salmo salar) using microsatellites. Animal Genetics.. 29: 363-370.

Ostberg CO, Rodriguez RJ. 2002. Novel molecular markers differentiate Oncorhynchus mykiss (rainbow trout and steelhead) and the O. clarki (cutthroat trout) subspecies. Molecular Ecology Notes. 2: 197-202.

Overturf K, Rexroad C, Hardy RW, Casten MT, LaPatra SL. 2003. Comparison of growth performance, immunological response and genetic diversity of five strains of rainbow trout (Oncorhynchus mykiss). Aquaculture. 217: 93-106.

Ozaki A, Khoo SK, Sakamoto T, Okamoto N. 1999. Two highly polymorphic dinucleotide microsatellites in rainbow trout (Oncorhynchus mykiss): OmyRGT7TUF and OmyRGT8TUF. Animal Genetics. 30: 393-394.

Ozaki A, Sakamoto T, Khoo S, Nakamura K, Coimbra MRM, Akutsu T, Okamoto N. 2001. Quantitative trait loci (QTLs) associated with resistance/susceptibility to infectious pancreatic necrosis virus (IPNV) in rainbow trout (Oncorhynchus mykiss). Molecular Genetics and Genomics. 265: 23-31.

Ozaki A, Khoo SK, Sakamoto T, Okamoto N. 2003. Thirty-one polymorphic microsatellite markers for genetic mapping in rainbow trout (Oncorhynchus mykiss). Animal Genetics. 34: 315-317. 
Palti Y, Parsons JE, Thorgaard GH. 1996. Assessment of genetic variability among strains of rainbow and cutthroat trout using multilocus DNA fingerprints. Aquaculture. 149: 47-56.

Palti Y, Parsons JE, Thorgaard GH. 1997. Assessment of genetic variability among strains of rainbow and cutthroat trout using multilocus DNA fingerprints. Aquaculture. 149: 47-56.

Palti Y, Thorgaard GH, Parsons JE. 1999. Identification of candidate DNA markers associated with IHN virus resistance in backcrosses of rainbow (Oncorhynchus mykiss) and cutthroat trout (O. clarki). Aquaculture. 173: 81-94.

Palti Y, Parsons JE, Thorgaard GH, Nichols KM, Waller KI. 2001. Association between DNA polymorphisms tightly linked to MHC class II genes and IHN virus resistance in backcrosses of rainbow and cutthroat trout.. Aquaculture. 194: 283289.

Palti Y, Danzmann RG, Rexroad CE III. 2002a. Characterization and mapping of 19 polymorphic microsatellite markers for rainbow trout (Oncorhynchus mykiss). Animal Genetics. 34: 146-160.

Palti Y, Fincham MR, Rexroad CE III. 2002b. Characterization of 38 polymorphic microsatellite markers for rainbow trout (Oncorhynchus mykiss). Molecular Ecology Notes. 2: 449-452.

Palti Y, Danzmann RG, Rexroad CE. 2003. Characterization and mapping of 19 polymorphic microsatellite markers for rainbow trout (Oncorhynchus mykiss). Animal Genetics. 34: 153-156.

Palti Y, Gahr SA, Hansen JD, Rexroad CE III. 2004. Characterization of a new BAC library for rainbow trout: evidence for multi-locus duplication. Animal Genetics. 35: 130-133.

Palva TK, Lehvaslaiho H, Palva ET. 1989. Identification of anadromous and non-anadromous salmon stocks in Finland by mitochondrial DNA analysis. Aquaculture. 81: 237-244.

Pante MJR, Gjerde B, McMillan I. 2001a. Effect of inbreeding on body weight at harvest in rainbow trout, Oncorhynchus mykiss. Aquaculture. 192: 201-211.

Pante MJR, Gjerde B, McMillan I. 2001b. Inbreeding levels in selected populations of rainbow trout Oncorhynchus mykiss.. Aquaculture. 192: 213-224.

Pante JR, Gjerde B, McMillan I, Misztal I. 2002. Estimation of additive and dominance genetic variances for body weight at harvest in rainbow trout, Oncorhynchus mykiss. Aquaculture. 204: 383-392. 
Parkinson EA. 1984. Genetic variation in populations of steelhead trout (Salmo gairdneri) in British Columbia. Canadian Journal of Fisheries and Aquatic Sciences. 41: 1412-1420.

Patanjali SR, Parimoo S, Weissman SM. 1991. Construction of a uniformabundance (normalized) cDNA library. Proceedings of the National Academy of Sciences, USA. 88: 1943-7.

Peacock MM, Neville H, Kirchoff VS. 2004. Ten species specific microsatellite marker for Lahontan cutthroat trout, Oncorhynchus clarki henshawi. Molecular Ecology Notes. 4: 557-559.

Pendas AM, Moran P, Martinez JL, Garcia-Vazquez E. 1995. Applications of 5S rDNA in Atlantic salmon, brown trout, and in Atlantic salmon X brown trout hybrid. Molecular Ecology. 4: 275-276.

Perry GML, Danzmann RG, Ferguson MM, Gibson JP. 2001. Quantitative trait loci for upper thermal tolerance in outbred strains of rainbow trout (Oncorhynchus mykiss). Heredity. 86: 333-341.

Perry GML, Ferguson MM, Danzmann RG. 2003. Effects of genetic sex and genomic background on epistasis in rainbow trout (Oncorhynchus mykiss). Genetica. 119: 35-50.

Perry GML, Ferguson MM, Sakamoto T, Danzmann RG. 2005. Sex-linked quantitative trait loci for thermotolerance and length in the rainbow trout. Journal of Heredity. 96: 97-107.

Phillips RB, Zimmermann A, Noakes MA, Palti Y, Morasch MRW, Eiben L, Ristow SS, Thorgaard GH, Hansen JD. 2003. Physical and genetic mapping of the rainbow trout major histocompatability regions: evidence for duplication of the class I region. Immunogenetics. 55: 561-569.

Phillips RB, Pleyte KA, Brown MR. 1992. Salmonid phylogeny inferred from ribosomal DNA restriction maps. Canadian Journal of Fisheries and Aquatic Sciences. 49: 2345-2353.

Presa P, Guyomard R. 1996. Conservation of microsatellites in three species of salmonids. Journal of Fish Biology. 49: 1326-1329.

Primmer CR, Landry PA, Ranta E, Merila J, Piironen J, Tiira K, Peuhkuri N, Pakkasmaa S, Eskelinen P. 2003. Prediction of offspring fitness based on parental genetic diversity in endangered salmonid populations. Journal of Fish Biology. 63: 909-927. 
Prodöhl PA, Taggart JB, Ferguson A. 1992. Genetic variability within and among sympatric brown trout (Salmo trutta) populations: multi-locus DNA fingerprint analysis. Hereditas. 177: 45-50.

Prodöhl PA, Taggart JB, Ferguson A. 1994. Single locus inheritance and joint segregation analysis of minisatellite (VNTR) DNA loci in brown trout (Salmo trutta L.) Heredity. 73: 556-566.

Prodöhl PA, Taggart JB, Ferguson A. 1995. A panel of minisatellite (VNTR) DNA locus specific probes for potential application to problems in salmonid aquaculture. Aquaculture, 137, 87-97

Prodöhl PA, Walker AF, Hynes R, et al., 1997. Genetically monomorphic brown trout (Salmo trutta L.) populations, as revealed by mitochondrial DNA, multilocus and single-locus minisatellite (VNTR) analyses. Heredity. 79: 208213.

Purvis IW, Franklin IR. 2005. Major genes and QTL influencing wool production and quality: a review. Genetics, Selection, Evolution. 37 (Suppl 1): S97-S107.

Queller DC, Goodnight KF. 1989. Estimating relatedness using genetic markers. Evolution. 43: 258-275.

Ramstad KM, Woody CA, Sage GK, Allendorf FW. 2004. Founding evens influence genetic population structure of sockeye salmon (Oncorhynchus nerka) in Lake Clark, Alaska. Molecular Ecology. 13: 277-290.

Reid D, Szanto A, Glebe B, Danzmann RG, Ferguson MM. 2005. QTL for body weight and condition factor in Atlantic salmon (Salmo salar): comparative analysis with rainbow trout (Oncorhynchus mykiss) and Arctic charr (Salvelinus alpinus). Heredity. 94: 166-172.

Reinitz GL. 1977a. Electrophoretic distinction of rainbow trout (Salmo gairdneri), west-slope cutthroat trout (S. clarkii), and their hybrids. Journal of the Fisheries Research Board of Canada. 34: 1236-1239.

Reinitz GL, Orme LE, Hitzel FN. 1979. Variations in body composition and growth among strains of rainbow trout. Transactions of the American Fisheries Society. 108: 204-207.

Reisenbichler RR, McIntyre JD. 1977. Genetic differences in growth and survival of juvenile hatchery and wild steelhead trout. Journal of the Fisheries Research Board of Canada. 34: 123-128. 
Reisenbichler RR, Phelps SR. 1989. Genetic variation in steelhead (Salmo gairdneri). from the north coast of Washington. Canadian Journal of Fisheries and Aquatic Sciences. 46: 66-73.

Reisenbichler RR, McIntyre JD, Solazzi MF, Landino SW. 1992. Genetic variation in steelhead of Oregon and northern California. Transactions of the American Fisheries Society. 121: 158-169.

Rexroad CE III, Coleman RL, Martin AM, Hershberger WK, Killefer J. 2001. Thirty-five polymorphic microsatellite markers for rainbow trout (Oncorhynchus mykiss). Animal Genetics. 32: 317-319.

Rexroad CE III, Coleman RL, Gustafson AL, Hershberger WK, Killefer J. 2002a. Development of rainbow trout microsatellite markers from repeat enriched libraries. Marine Biotechnology. 3: 12-16.

Rexroad, CE III, Coleman RL, Hershberger WK, Killefer J. 2002b. Eighteen polymorphic microsatellite markers for rainbow trout (Oncorhynchus mykiss). Animal Genetics. 33: 76-78.

Rexroad, CE III, Coleman RL, Hershberger WK, Killefer J. 2002c. Rapid communication: Thirty-eight polymorphic microsatellite markers for mapping in rainbow trout. Journal of Animal Science. 80: 541-542.

Rexroad CE III, Palti Y. 2003. Development of ninety-seven polymorphic microsatellite markers for rainbow trout. Transactions of the American Fisheries Society. 132: 1214-1221.

Rexroad C, Thorgaard G, Palti Y, Hansen J et al. 2004. A proposal advocating draft sequencing the genome of the rainbow trout Oncorhynchus mykiss. Community Sequencing Program Project Proposal. USDA/ARS National Center for Cool and Cold Water Aquaculture. http://www.animalgenome.org/aquaculture/salmonids/RainbowProposal.pdf

Rexroad CE, Rodriguez MF, Coulibaly I, Gharbi K, Danzmann RG, DeKoning J, Phillips R, Palti Y. 2005. Comparative mapping of expressed sequence tags containing microsatellites in rainbow trout (Oncorhynchus mykiss). BMC Genomics. 6: 54.

Rezk MA, Smitherman RO, Williams JC, Nichols A, Kucuktas H, Dunham RA. 2003. Response to three generations of selection for increased body weight in channel catfish, Ictalurus punctatus, grown in earthen ponds. Aquaculture. 228: 69-79. 
Rieseberg LH, Sinervo B, Linder CR, Ungerer MC, Arias DM. 1996. Role of gene interactions in hybrid speciation: evidence from ancient and experimental hybrids. Science, News Series, 272: 741-745.

Rodriguez MF, LaPatra S, Williams S, Famula T, May B. 2004. Genetic markers associated with resistance to infectious hematopoietic necrosis in rainbow and steelhead trout Oncorhynchus mykiss) backcrosses. Aquaculture. 241: 93-115.

Rodriguez F, Palti Y, Rexroad CE III. 2003. Characterization of twenty-four microsatellite markers for rainbow trout (Oncorhynchus mykiss). Molecular Ecology Notes. 3: 619-622.

Rossi CMR, Lessa EP, Pascual MA. 2004. The origin of introduced rainbow trout (Oncorhynchus mykiss) in the Santa Cruz River, Patagonia, Argentina, as inferred from mitochondrial DNA. Canadian Journal of Fisheries and Aquatic Sciences. 64: 1095-1101.

Rubridge E, Corbett P, Taylor EB. 2001. A molecular analysis of hybridization between native westslope cutthroat trout and introduced rainbow trout in southeastern British Columbia, Canada. Journal of Fish Biology. 59: (Suppl. A): $42-54$.

Ruzzante DE, Hansen MM, Meldrup D, Ebert KM. 2004. Stocking impact and migration pattern in anadromous brown trout (Salmo trutta) complex: where have all the stocked spawning sea trout gone? Molecular Ecology. 13: 1433-1445.

Ryman N, Allendorf FW, Ståhl G. 1979. Reproductive isolation with little genetic divergence in sympatric populations of brown trout (Salmo trutta). Genetics. 92: 247-262.

Ryman N, Stahl G. 1980. Genetic changes in hatchery stocks of brown trout (Salmo trutta). Canadian Journal of Fisheries and Aquatic Sciences. 37: 82-87.

Ryman N. 1983. Patterns of distribution of biochemical variation in salmonids: differences between species. Aquaculture. 33: 1-21

Ryman N, Utter F. 1987. Preface. Population Genetics and Fishery Management. pp. ix. Ryman N, Utter F, eds. University of Washington Press, Seattle, WA.

Ryman N, Utter F, Allendorf FW, Busack C, Shaklee J. 1993. Genetic concerns about hatchery populations - A comment on conclusions of Nyman and Ring. Journal of Fish Biology. 42: 471-419.

Ryman N. 1995. Genetic population structure. In: Genetic Effects of Straying of Non-Native Hatchery Fish into Natural Populations. NOAA Tech Memo 
NMFS NWFSC-30:

Sajedi RH, Aminzadeh S, haderi-Manesh H, sadeghizadeh M, abdolhay $\mathrm{H}$, Naderi-Manesh M. 2003. Genetic variation within and among rainbow trout, Oncorhynchus mykiss, hatchery populations from Iran assessed by PCR-RFLP analysis of mitochondrial DNA segments. Journal of Food Science. 68: 870873.

Sakamoto T, Okamoto N, Ikeda Y, nakamura Y, Sato T. 1994. Dinucleotiderepeat polymorphism in DNA of rainbow trout and its application in fisheries sciences. Journal of Fish Biology. 44: 1093-1096.

Sakamoto T, Ferguson MM, Ihssen PE, Danzmann RG, Okamoto N. 1999. Linkage analysis of quantitative trait loci associated with spawning time in rainbow trout (Oncorhynchus mykiss). Aquaculture. 173: 33-43.

Sakamoto T, Danzmann RG, Gharbi K, Howard P, Ozaki A, Khoo SK, Woram RA, Okamoto N, Ferguson MM, Holm LE, Guyomard R, Hoyheim B. 2000. A microsatellite linkage map of rainbow trout (Oncorhynchus mykiss) characterized by large sex-specific differences in recombination rates. Genetics. 155: 13311345.

Sakamoto T. 2004. Construction of genetic linkage maps and QTL analysis using microsatellite markers in fish. Nippon Suisan Gakkaishi. 70: 496-499.

Sanchez JA, Blanco G, Vazquez E, Garcia E, Rubio J. 1991. Allozyme variation in natural population of Atlantic salmon in Asturias (Northern Spain). Aquaculture. 93: 23-32.

Sanchez JA, Clabby C, Ramos D, Blanco G, Flavin F, Vasquez E, Powell R. 1996. Protein and microsatellite single locus variability in Salmo salar L. (Atlantic salmon). Heredity. 77: 423-432.

Sanger F, Nicklen, S, Coulson, AR. 1977. DNA sequencing with chainterminating inhibitors. Proceedings of the National Academy of Sciences, USA. 74: 5463-7.

Sanz N, Garcia-Marin JL, Pla C. 2002. Managing fish population under mosaic relationships. The case of the brown trout (Salmo trutta) in peripheral Mediterranean populations. Conservation Genetics. 4: 385-400.

Sasaki YF, Iwasaki T, Kobayashi H, Tsuji S, Ayusawa D, Oishi M. 1994. Construction of an equalized cDNA library from human brain by semi-solid selfhybridization system. DNA Research. 1: 91-6. 
Scheerer PD, Thorgaard GH, Allendorf FW. 1991. Genetic analysis of androgenetic rainbow trout. Journal of Experimental Zoology. 260: 382-390.

Scribner KT, Gust JR, Fields RL. 1996a. Isolation and characterization of novel microsatellite loci: cross-species amplification and population genetics applications. Canadian Journal of Fisheries and Aquatic Sciences. 53: 841-883.

Scribner KT, Gust JR, Fields RL. 1996b. Isolation and characterization of novel salmon microsatellite loci: cross-species amplification and population genetics applications. Canadian Journal of Fisheries and Aquatic Sciences. 53: 833-841.

Seamons TR, Bentzen P, Quinn TP. 2004. The mating system of steelhead, Oncorhynchus mykiss, inferred by molecular analysis of parents and progeny. Environmental Biology of Fishes. 69: 333-344.

Seelbach PW, Whelan GE. 1988. Identification and contribution of wild and hatchery steelhead stocks in Lake Michigan tributaries. Transactions of the American Fisheries Society. 117: 444-451.

Shaklee JB, Klaybor DC, Young S, White B. 1991. Genetic stock analysis of odd-year pink salmon, Oncorhynchus gorbuscha, Walbaum, from Washington and British Columbia and potential mixed-stock fisheries applications. Journal of Fish Biology. 39 (suppl A): 21-34.

Shaklee JB, Ames J, LaVoy L. 1996. Genetic diversity units and major ancestral lineages for sockeye salmon in Washington. Technical report RAD 95-02. WDFW, Fish Management program, Resource Assessment Division. Olympia, WA.

Siitonen L, Gall GAE. 1989. Response to selection for early spawn date in rainbow trout, Salmo gairdneri. Aquaculture. 78: 153-161.

Silverstein JT, Rexroad CE III, King TL. 2004. Genetic variation measured by microsatellites among three strains of domesticated rainbow trout (Oncorhynchus mykiss, Walbaum). Aquaculture Research. 35: 40-48.

Skaala Ø, Jorstad KE, Borgstrom R. 1996. Genetic impact on two wild brown trout (Salmo trutta) populations after release of non-indigenous hatchery spawners. Canadian Journal of Fisheries and Aquatic Sciences. 53: 2027-2035.

Skaala Ø, Makhrov AA, Karlsen T, Jorstad KE, Altukhov YO, Politov DV, Kuzishin KV, Novikov GG. 1998. Genetic comparison of salmon from the White Sea and north-western Atlantic Ocean. Journal of Fish Biology. 53: 569580 . 
Skilbrei OT, Wennevik V. 2004. A comparative study of the performance of family groups of Atlantic salmon reared in tanks and released in a river. Journal of Fish Biology. 65 (suppl. A): 322 (abstract).

Skulason S, Snorrason SS, Noakes DLG, Ferguson MM, Malmquist HJ. 1989. Segregation in spawning and early life history among polymorphic Arctic charr, Salvelinus alpinus, in Thingvallavtn, Iceland. Journal of Fish Biology. 35 (Suppl. A): 225-232.

Small MP, Beacham TD, Withler RE, Nelson RJ. 1998. Discriminating coho salmon (Oncorhynchus kitsutch) populations within the Frasier River, British Columbia, using microsatellite DNA markers. Molecular Ecology. 7: 41-155.

Smith GR, Stearley RF. 1989. The classification and scientific names of rainbow and cutthroat trouts. Fisheries. 14: 4-10.

Smith CT, Koop BF, Nelson RJ. 1998. Isolation and characterization of coho salmon (Oncorhynchus kisutch) microsatellites and their use in other salmonids. Molecular Ecology. 7: 1613-1621.

Smouse PE, Chevillon C. 1998. Analytical aspects of population-specific DNA fingerprinting for individuals. Journal of Heredity. 89: 143-150.

Somorjai KML, Danzmann RG, Ferguson MM. 2003. Distribution of temperature tolerance quantitative trait loci in Artcic charr (Salvelinus alpinus) and inferred homologies in rainbow trout (Oncorhynchus mykiss). Genetics. 165: 1443-1456.

Spruell P, Green BA, Habicht C, Knudsen KL, Lindner KR, Olsen JB, Pilgrim KL, Sage GK, Seeb JE, Allendorf FW. 1999a. Inheritance of nuclear DNA markers in gynogenetic haploid pink salmon (Oncorhynchus gorbuscha). Journal of Heredity. 90: 289-296.

Spruell P, Bartron ML, Kanda N, Allendorf FW. 2001. Detection of hybrids between bull trout (Salvelinus confluentus) and brook trout (S. fontinalis) using PCR primers complementary to interspersed nuclear elements. Copeia. 2001: 1093-1099.

Spruell P, Hemmingsen AR, Howell PJ, Kanda N, Allendorf FW. 2003. Conservation genetics of bull trout: Geographic distribution of variation at microsatellite loci. Conservation Genetics. 4: 17-29.

Srivastava R, Kitambi SS, Goyal A. 2005. In silico analysis of thioredoxins and glutaredoxins. Journal of Plant Biochemistry and Biotechnology 14: 121-126 
Stahl G. 1983. Differences in the amount and distribution of genetic variation between natural populations and hatchery stocks of Atlantic salmon.

Aquaculture. 33: 23-32.

Stahl G. 1987. Genetic population structure of Atlantic salmon. In: Population genetics and fishery management. pp. 121-140. Ryman N, Utter F, eds. University of Washington Press, Seattle, WA.

Stearley RF, Smith GR. 1993. Phylogeny of the Pacific trouts and salmons (Oncorhynchus) and genera of the family Salmonidae. Transactions of the American Fisheries Society. 122: 1-33.

Steinberg EK, Linder KR, Gallea J, Maxwell A, Meng J, Allendorf FW. 2002. Rates and patterns of microsatellite mutations in pink salmon. Molecular Biology and Evolution. 19: 1198-1202.

Stoneking B, May B, Wright JE. 1981. Loss of duplicate gene expression in salmonids: evidence for a null allele polymorphism at the duplicate aspartate aminotransferase locus in brook trout (Salvelinus fontinalis). Biochemical Genetics. 19: 1063-1077.

Su GS, Liljedahl LE, Gall GAE. 1996a. Effects of inbreeding on growth and reproductive traits in rainbow trout (Oncorhynchus mykiss). Aquaculture. 142: 139-148.

Su G. 1996b. Genetics and environmental variation of body weight in rainbow trout (Oncorhynchus mykiss). Aquaculture. 1244: 71-80.

Su G. 1997. Genetic and environmental variation of female reproductive traits in rainbow trout (Oncorhynchus mykiss). Aquaculture. 154: 115-124

Taggart JB, Ferguson A. 1990. Hypervariable single locus DNA probes for the Atlantic salmon, Salmo salar L. Journal of Fish Biology. 37: 991-993.

Taggart JB, Prodöhol PA, Ferguson A. 1995a. Genetic markers for Atlantic salmon (Salmo salar L.) single locus inheritance and joint segregation analysis of minisatellite (VNTR) DNA loci. Animal Genetics. 26: 13-20.

Taggart JB, Verspoor E, GalvinPT, Moran P, Ferguson A. 1995b. A minisatellite DNA marker for discriminating between European and North American Atlantic salmon (Salmo salar). Canadian Journal of Fisheries and Aquatic Sciences. 52: 2305-2311.

Taylor EB. 1991. A review of local adaptation in Salmonidae, with particular reference to Pacific and Atlantic salmon. Aquaculture. 98: 185-207. 
Taylor EB, Beacham TD, Kaeriyama M. 1994. Population structure and identification of North Pacific Ocean chum salmon (Oncorhynchus keta) revealed by an analysis of minisatellite DNA variation. Canadian Journal of Fisheries and Aquatic Sciences. 51: 1430-1442.

Taylor EB. 1995. Genetic variation of minisatellite DNA loci among North Pacific populations of steelhead and rainbow trout (Oncorhynchus mykiss). Journal of Heredity. 86: 354-363.

Taylor EB, Foote CJ, Wood CC. 1996. Molecular genetic evidence for parallel life history evolution within a Pacific salmon (sockeye salmon and kokanee, Oncorhynchus nerka). Evolution. 50: 401-416.

Tessier N, Bernatchez L, Presa P, Angers B. 1995. Gene diversity analysis of mitochondrial DNA, microsatellites and allozymes in landlocked Atlantic salmon. Journal of Fish Biology. 47 (Suppl. A): 156-163.

Tessier N, Bernatchez L. 1999. Stability of population structure and genetic diversity across generations assessed by microsatellites among sympatric populations of landlocked Atlantic salmon (Salmo salar L.). Molecular Ecology. 8: $169-179$.

Thelen GC, Allendorf FW. 2001. Heterozygosity-fitness correlations in rainbow trout: effects of allozyme loci or associative overdominance? Evolution. 55: $1180-1187$.

Thomas WK, Withler RE, Beckenbackh AT. 1986. Mitochondrial DNA analysis of Pacific salmonid evolution. Canadian Journal of Zoology. 64: 1058-1064.

Thompson D. 1985. Genetic identification of trout strains. Aquaculture. 46: $341-351$.

Thorgaard GH. 1977. Chromosome studies of steelhead. In Hassler, TJ, VanKirk RR, editors. Proceedings of the Genetic Implications of Steelhead management Symposium, May 20-21, Arcata, CA; Special Report 7701. Calif. Coop. Fish. Res. Unit. Pp.. 20-25.

Thorgaard GH, Gall GAE. 1979. Adult triploids in a rainbow trout family. Genetics. 93: 961-973.

Thorgaard GH. 1983a. Chromosomal differences among rainbow trout populations. Copecia. pp 650-662.

Thorgaard GH. 1983b. Chromosome set manipulation and sex control in fish. In: Hoar WS, Randall DJ, Donaldson EM, editors. Fish Physiology. Vol. 9B. Academic Press, New York, NY. pp. 405-534. 
Thorgaard GH, Allendorf FW, Knudsen KL. 1983c. Gene-centromere mapping in rainbow trout: High interference over long map distances. Genetics. 103: 771-783.

Thorgaard GH, Allendorf FW. 1988. Developmental genetics of fishes. In: Developmental Genetics of Animals and Plants. Malacinski GM, editor. Macmillan Publishing Company. pp. 363-391.

Thorgaard GH. 1992. Application of genetic technologies to rainbow trout. Aquaculture. 100: 85-97.

Thorgaard GH, Bailey GS, Williams D, Buhler DR, Kaattari SL, Ristow SS, Hansen JD, Winton JR, Bartholomew JL, Nagler JJ, Walsh PJ, Vijayan MM, Devlin RH, Hardy RW, Overturf KE, Young WP, Robison BD, Rexroad C III, Palti Y. 2002. A white paper advocating complete sequencing of the genome of the rainbow trout.

http://www.animalgenome.org/aquaculture/salmonids/RainbowWhitePaper.pdf

Thorgaard GH, Winton JR, Hansen JD, Nagler JJ, Bartholomew JL, Ristow SS, Williams D, Bailey GS, Kaattari SL, Buhler DR. 2002. Status and opportunities for genomics research with rainbow trout. Comparative Biochemistry and Physiology. Part B, Biochemistry and Molecular Biology. 133B: 609-646.

Tipping JM. 1991. Heritability of age at maturity in steelhead. North American Journal of Fisheries Management. 11L 105-108.

Tymchuk WE, Devlin RH. 2005. Growth differences among first and second generation hybrids of domesticated and wild rainbow trout (Oncorhynchus mykiss). Aquaculture. 245: 295-300.

United States Department of Agriculture. NASS Fact Finder for Agriculture: Trout Production. http://usda.mannlib.cornell.edu/reports/nassr/other/ztp-bb/trpr0205.pdf

Utter FM. 1971. Tetrazolium oxidase phenotypes of rainbow trout. (Salmo gairdneri) and Pacific salmon (Oncorhynchus sp.). Comparative Biochemistry and Physiology. 39B: 891-895.

Utter FM, Hodgins H. 1972. Biochemical genetic variants at six loci in four stocks of rainbow trout. Transactions of the American Fisheries Society. 101: 494-502.

Utter FM, Allendorf FW. 1994. Phylogenetic relationships among species of Oncorhynchus: A consensus view. Conservation Biology. 8: 864-867. 
Van Oosterhaut C, Weetman D, Hutchinson WF. 2006. Estimation and adjustment of microsatellite null alleles in non equilibrium populations. Molecular Ecology Notes. 6: 255-256.

Varnavskaya NV, Wood CC, Everett RJ. 1994. Genetic variation in sockeye (Oncorhynchus nerka) populations of Asia and North America. Canadian Journal of Fisheries and Aquatic Sciences. 51: (Suppl. 1): 132-146.

Vazquez E, Presa P, Sanchez JA, Blanco G, Utter F. 1993. Genetic characterization of introduced populations of Atlantic salmon, Salmo salar, in Asturias (Northern Spain). Hereditas. 119: 47-51.

Verspoor E. 1988. Reduced genetic variability in first-generation hatchery populations of Atlantic salmon (Salmo salar). Canadian Journal of Fisheries and Aquatic Sciences. 45: 1686-1690.

Verspoor E, Jordan WC. 1989. Genetic variation at the Me-2 locus in the Atlantic salmon within a Scottish river: evidence for its selective maintenance. Journal of Fish Biology. 35 (Suppl. A): 205-230.

Verspoor E, Fraxier NH, Youngson AF. 1991. Protein polymorphism in Atlantic salmon within a Scottish river: evidence for selection and estimates of gene flow between tributaries. Aquaculture. 98: 227-230.

Verspoor E, McCarthy E. 1997. Genetic divergence at the NAD+-dependent malic enzyme locus in Atlantic salmon from Europe and North America. Journal of Fish Biology. 51: 155-163.

Verspoor E, Beardmore JA, Consuegra S, Garcia de Leaniz C, Hindar K, Jordan WC, Koljonen ML, Mahkrov AA, Paaver T, Sanchez JA, Skaala Ø, Titov S, Cross TF. 2005. Population structure in the Atlantic salmon: insights from 40 years of research into genetic protein variation. Journal of Fish Biology. 67: 354.

Verspoor E. 2005. Regional differentiation of North American Atlantic salmon at allozyme loci. Journal of Fish Biology. 67 (suppl. A): 80-103.

von Schalburg KR, Rise ML, Cooper GA, Brown GD, Gibbs AR, Nelson CC, Davidson WS, Koop BF. 2005 Fish and chips: various methodologies demonstrate utility of a 16,006-gene salmonid microarray. BMC Genomics. (6): 126.

Vuorinen J. 1982. Little genetic variation in the Finnish Lake salmon, Salmo salar sebago (Girard). Hereditas. 97: 189-192. 
Wagner HH, Walace RL, Campbell HJ. 1963. the seaward migration and return of hatchery-reared steelhead trout, Salmo gairdneri Richardson, in the Alsea River, Oregon. Transactions of the American Fisheries Society. 92: 202-210.

Waples RS. 1990. Temporal changes of allele frequency in Pacific salmon: implication for mixed-stock fishery analysis. Canadian Journal of Fisheries and Aquatic Sciences. 47: 968-976.

Waples, RS. 1991. Definition of "species" under the endangered species act: application to pacific salmon. NOAA Technical Memorandum NMFS F/NWC194. National marine Fisheries Service, Northwest Fisheries Science Center, Seattle, WA.

Waples RS, Gustafson RG, Weitkamp LA, Myers JM, Johnson OW, Busby PJ, Hard JJ, Bryant GJ, Waknitz FW, Neely K, Teel D, Grant WS, Winans GA, Phelps S, Marshall A, Baker BM. 2001. Characterizing diversity in salmon from the Pacific Northwest. Journal of Fish Biology. 59 (suppl. A): 1-41.

Wanglia BCC, Dick TA. 1988. Influence of genotype and temperature on the relationship between specific growth rate and size of rainbow trout. Transactions of the American Fisheries Society. 117: 560-564.

Ward RD, Maguire GB, Jorstad KE. 2003. Microsatellite diversity in rainbow trout (Oncorhynchus mykiss) introduced to Western Australia. Aquaculture. 219: 169-179.

Weissenbach J, Gyapay G, Dib C et al., 1992. A second-generation map of the human genome. Nature. 359: 794-801.

Whiteley AR, Spruell P, Allendorf FW. 2004. Ecological and life history characteristics predict population genetic divergence of two salmonids in the same landscape. Molecular Ecology. 13: 3675-3688.

Williams RN, Powell MS. 2000. Genetic analysis of rainbow trout (Oncorhynchus mykiss) from Silver Creek Preserve of the Nature Conservancy, Idaho. Lab Report HAG-00-2. Center for Salmonid and Freshwater Species at Risk, HFCES, University of Idaho.

Wilmot RL, Everett RJ, Spearman WJ, Baccus R, Varnavaskaya NV, Putivkin SV. 1994. Genetic stock structure of western Alaska chum salmon and a comparison with Russian Far East stocks. Canadian Journal of Fisheries and Aquatic Sciences. 51 (suppl. 1): 84-94.

Wilson AJ, Gislason D, Skulason S, Snorrason SS, Adams CE, Alexander G, Danzmann RG, Ferguson MM. 2004. Population genetic structure of Artic 
Charr, Salvelinus alpinus from northwest Europe on large and small spatial scales. Molecular Ecology. 13: 1129-1142.

Wilson GM, Thomas WK, Beckenbach AT. 1985. Intra- and inter-specific mitochondrial DNA sequence divergence in Salmo: rainbow, steelhead, and cutthroat trouts. Canadian Journal of Zoology. 63: 2088-2094.

Wilson GM, Thomas WK, Beckenbach AT. 1987. Mitochondrial DNA analysis of Pacific northwest populations of Oncorhynchus tshawytscha. . Canadian Journal of Fisheries and Aquatic Sciences. 51 (suppl. 1): 95-113.

Winans GA, Aebersold PB, Urawa S, Varnavskaya N. 1994. Determining continent of origin of chum salmon using genetic stock identification techniques: status of allozyme baseline in Asia. Canadian Journal of Fisheries and Aquatic Science 51(Supplement 1): 95113.

Winans GA, Aebersold PB, Waples RS. 1996. Allozyme variability of Oncorhynchus nerka in the Pacific Northwest, with special consideration to populations of Redfish Lake, Idaho. Transactions of the American Fisheries Society. 125: 645-663.

Withler IL. 1966. Variability in the life history characteristics of steelhead trout (Salmo gairdneri) along the Pacific coast of North America. Journal of the Fisheries Research Board of Canada. 23:365-392.

Withler RE. 1988. Genetic consequences of fertilizing chinook salmon (Oncorhynchys tshawytscha) eggs with pooled milt. Aquaculture. 68: 15-25.

Withler RE, Le KD, Nelson RJ, Miller KM, Beacham TD. 2000. Intact genetic structure and high levels of genetic diversity in bottlenecked sockeye salmon, Oncorhynchus nerka, populations of the Frasier River, British Columbia, Canada. Canadian Journal of Fisheries and Aquatic Sciences. 57: 1985-1998.

Wood CC, Rutherford DT, McKinnell S. 1989. Identification of sockeye salmon (Oncorhynchus nerka) stocks in mixed-stock fisheries in British Columbia and Southeast Alaska using biological markers. Canadian Journal of Fisheries and Aquatic Sciences. 46: 2108-2120.

Wood CC, Foote CJ. 1996. Evidence for sympatric genetic divergence of anadromous and non-anadromous morphs of sockeye salmon (Oncorhynchus nerka). Evolution. 50: 1265-1279.

Woodward CC, Strange RJ. 1987. Physiological stress responses in wild and hatchery-reared rainbow trout. Transactions of the American Fisheries Society. 116: $574-579$. 
Woram, RA, Kharbi K, Sakamoto T, Hoyheim B, Holm LK, Naish K, McGowan C, Ferguson MM, Phillips RB, Stein J, Guyomard R, Cairney M, Taggart JB, Powell R, Davidson W, Danzmann RG. 2003a. Comparative genome analysis of the primary sex-determining locus in salmonid fishes. Genome Research. 13: 272-280.

Woram RA, McGowan C, Stout JA, Gharbi K, Ferguson MM, Hoyheim B, Davidson EA, Davidson WS, Rexroad C, Danzmann RG. 2003b. A genetic linkage map for Arctic char (Salvelinus alpinus): evidence for higher recombination rates and segregation distortion in hybrid versus pure strain mapping parents. Genome. 47: 304-315.

Woram RA, McGowan C, Stout JA, Gharbi K, Ferguson MM, Hoyheim B, Davidson EA, Davidson WS, Rexroad C, Danzmann RG. 2004. A genetic linkage map for Arctic char (Salvelinus alpinus): evidence for higher recombination rates and segregation distortion in hybrid versus pure strain mapping parents. Genome. 47: 304-315.

Wright S. 1922. The effects of inbreeding and crossbreeding on guinea pigs. III. Crosses between highly inbred families. USDA Bull. 1121: 1-60.

Wright JE, Atherton LM. 1968. Polymorphism for LDH and transferring loci in brook trout populations. Transactions of the American Fisheries Society. 99: 179-192.

Wright JE, May B, Stoneking M, Lee G. 1981. Pseudolinkage of the duplicate loci for supernatant aspartate aminotransferase in brook trout, Salvelinus fontinalis. Journal of Heredity. 71: 223-228.

Young WP, Wheeler PA, Fields RD, Thorgaard GH. 1996. DNA fingerprinting confirms isogenicity of androgenetically derived rainbow trout lines. Journal of Heredity. 87: 77-80.

Young WP, Wheeler PA, Coryell VH, Keim P, Thorgaard GH. 1998. A detailed linkage map of rainbow trout produced using doubled haploids. Genetics. 148: 839-850.

Youngson AF, Martin SAM, Jordan WC, Verspoor E. 1991. Genetic protein variation in Atlantic salmon in Scotland: comparison of wild and farmed fish. Aquaculture. 98: 231-242.

Zimmerman AM, Evenhuis JP, Thorgaard GH, Ristow SS. 2004. A single major chromosomal region controls natural killer cell-like activity in rainbow trout. Immunogenetics. 55: 825-835. 
Table 1. Species of Salmonidae, Fishery and Culture Status

\begin{tabular}{|l|c|c|c|}
\hline \multicolumn{1}{|c|}{ Scientific Name } & fishery & aquaculture & gamefish \\
\hline Acantholingua ohridana & commercial & experimental & - \\
\hline Brachymystax lenok & commercial & - & - \\
\hline Brachymystax savinovi & - & - & - \\
\hline Coregonus zenithicus & - & - & - \\
\hline Coregonus zuerichensis & - & - & - \\
\hline Coregonus zugensis & - & - & - \\
\hline Coregonus albellus & - & - & - \\
\hline Coregonus albula & commercial & experimental & - \\
\hline Coregonus alpenae & - & - & - \\
\hline Coregonus alpinus & - & - & - \\
\hline Coregonus arenicolus & - & - & - \\
\hline Coregonus artedi & commercial & - & yes \\
\hline Coregonus atterensis & - & - & - \\
\hline Coregonus autumnalis autumnalis & commercial & - & - \\
\hline Coregonus autumnalis migratorius & commercial & - & - \\
\hline Coregonus bavaricus & - & - & - \\
\hline Coregonus bezola & - & - & - \\
\hline Coregonus candidus & - & - & - \\
\hline Coregonus chadary & - & - & - \\
\hline Coregonus clupeaformis & commercial & - & yes \\
\hline Coregonus clupeoides & - & - & - \\
\hline Coregonus confusus & - & - & - \\
\hline Coregonus danneri & - & - & - \\
\hline Coregonus fatioi & - & - & - \\
\hline
\end{tabular}




\begin{tabular}{|l|c|c|c|}
\hline Scientific Name & fishery & aquaculture & gamefish \\
\hline Coregonus fera & - & - & - \\
\hline Coregonus fontanae & - & - & - \\
\hline Coregonus gutturosus & - & - & - \\
\hline Coregonus heglingus & - & - & - \\
\hline Coregonus hiemalis & - & - & - \\
\hline Coregonus hoferi & - & - & - \\
\hline Coregonus hoyi & - & - & - \\
\hline Coregonus huntsmani & - & - & - \\
\hline Coregonus johannae & - & - & - \\
\hline Coregonus kiyi & - & - & - \\
\hline Coregonus laurettae & subsistence & - & - \\
\hline Coregonus lavaretus baicalensis & - & - & - \\
\hline Coregonus lavaretus lavaretus & commercial & commercial & yes \\
\hline Coregonus lucidus & - & - & - \\
\hline Coregonus lucinensis & - & - & - \\
\hline Coregonus macrophthalmus & minor & commercial & - \\
\hline Coregonus maraena & - & - & - \\
\hline Coregonus maxillaris & - & - & - \\
\hline Coregonus megalops & - & - & - \\
\hline Coregonus muksun & commercial & - & yes \\
\hline Coregonus nasus & subsistence & - & yes \\
\hline Coregonus nelsoni & - & - & - \\
\hline Coregonus nigripinnis & - & - & - \\
\hline Coregonus nilssoni & - & - & - \\
\hline Coregonus nobilis & - & - & - \\
\hline
\end{tabular}




\begin{tabular}{|l|c|c|c|}
\hline Scientific Name & fishery & aquaculture & gamefish \\
\hline Coregonus oxyrinchus & commercial & commercial & - \\
\hline Coregonus palaea & - & - & - \\
\hline Coregonus pallasii & - & - & - \\
\hline Coregonus peled & commercial & commercial & - \\
\hline Coregonus pennantii & - & - & - \\
\hline Coregonus pidschian & commercial & commercial & - \\
\hline Coregonus pollan & commercial & - & - \\
\hline Coregonus reighardi & - & - & - \\
\hline Coregonus renke & - & - & - \\
\hline Coregonus restrictus & - & - & - \\
\hline Coregonus sardinella & commercial & - & yes \\
\hline Coregonus stigmaticus & - & - & - \\
\hline Coregonus subautumnalis & - & - & - \\
\hline Coregonus suidteri & - & - & - \\
\hline Coregonus trybomi & - & - & - \\
\hline Coregonus tugun lenensis & - & - & - \\
\hline Coregonus tugun tugun & - & - & - \\
\hline Coregonus ussuriensis & - & - & - \\
\hline Coregonus vandesius & minor & - & - \\
\hline Coregonus wartmanni & experimental & - \\
\hline Coregonus widegreni & - & - & - \\
\hline Hucho bleekeri & commercial & - & - \\
\hline Hucho hucho & - & - & yes \\
\hline Hucho ishikawae & - & - & - \\
\hline Hucho perryi & - & - & - \\
\hline
\end{tabular}




\begin{tabular}{|l|c|c|c|}
\hline Scientific Name & fishery & aquaculture & gamefish \\
\hline Hucho taimen & commercial & experimental & yes \\
\hline Oncorhynchus aguabonita & - & - & yes \\
\hline Oncorhynchus apache & - & - & yes \\
\hline Oncorhynchus chrysogaster & minor & - & - \\
\hline Oncorhynchus clarkii clarkii & commercial & commercial & yes \\
\hline Oncorhynchus clarki lewisi & - & - & yes \\
\hline Oncorhynchus clarki pleuriticus & - & - & - \\
\hline Oncorhynchus gilae & - & - & - \\
\hline Oncorhynchus gorbuscha & - & - & yes \\
\hline Oncorhynchus ishikawai & highly commercial & commercial & - \\
\hline $\begin{array}{l}\text { Oncorhynchus rhoduru; Oncorhynchus } \\
\text { masu ishikawai }\end{array}$ & - & & \\
\hline Oncorhynchus iwame & - & - & - \\
\hline Oncorhynchus keta & highly commercial & commercial & yes \\
\hline Oncorhynchus kisutch & highly commercial & commercial & yes \\
\hline Oncorhynchus masou formosanum & - & - & - \\
\hline Oncorhynchus masou macrostomus & - & commercial & yes \\
\hline Oncorhynchus masou masou & commercial & commercial & yes \\
\hline Oncorhynchus masou rhodurus & commercial & - & - \\
\hline Oncorhynchus mykiss & highly commercial & commercial & yes \\
\hline Oncorhynchus nerka & highly commercial & commercial & yes \\
\hline Oncorhynchus tshawytscha & highly commercial & commercial & yes \\
\hline Prosopium abyssicola & - & - & - \\
\hline Prosopium coulteri & of no interest & - & yes \\
\hline Prosopium cylindraceum & & - & yes \\
\hline
\end{tabular}




\begin{tabular}{|l|c|c|c|}
\hline Scientific Name & fishery & aquaculture & gamefish \\
\hline Prosopium gemmifer & - & - & - \\
\hline Prosopium spilonotus & - & - & - \\
\hline Prosopium williamsoni & minor & - & yes \\
\hline Salmo akairos & - & - & - \\
\hline Salmo aphelios & - & - & - \\
\hline Salmo balcanicus & - & - & - \\
\hline Salmo carpio & commercial & commercial & - \\
\hline Salmo cettii & - & - & - \\
\hline Salmo dentex & commercial & - & yes \\
\hline Salmo ezenami & - & - & - \\
\hline Salmo ferox & - & - & - \\
\hline Salmo fibreni & - & - & yes \\
\hline Salmo ischchan & commercial & - & yes \\
\hline Salmo labrax & - & - & - \\
\hline Salmo letnica & commercial & commercial & yes \\
\hline Salmo lumi & - & - & - \\
\hline Salmo macedonicus & - & - & - \\
\hline Salmo marmoratus & commercial & commercial & yes \\
\hline Salmo nigripinnis & - & - & - \\
\hline Salmo obtusirostris & commercial & - & yes \\
\hline Salmo pallaryi & of no interest & - & - \\
\hline Salmo pelagonicus & - & - & - \\
\hline Salmo peristericus & - & - & - \\
\hline Salmo platycephalus & - & - & - \\
\hline Salmo rhodanensis & commercial & - \\
\hline
\end{tabular}




\begin{tabular}{|l|c|c|c|}
\hline Scientific Name & fishery & aquaculture & gamefish \\
\hline Salmo salar & highly commercial & commercial & yes \\
\hline Salmo schiefermuelleri & - & - & - \\
\hline Salmo stomachicus & - & - & - \\
\hline Salmo taleri & - & - & - \\
\hline Salmo trutta aralensis & commercial & - & - \\
\hline Salmo trutta fario & commercial & commercial & yes \\
\hline Salmo trutta lacustris & minor & - & yes \\
\hline Salmo trutta macrostigma & - & - & - \\
\hline Salmo trutta oxianus & - & - & - \\
\hline Salmo trutta trutta & commercial & commercial & yes \\
\hline Salmo visovacensis & - & - & - \\
\hline Salmo zrmanjaensis & - & - & - \\
\hline Salvelinus agassizi & - & - & - \\
\hline Salvelinus albus & - & - & - \\
\hline Salvelinus alpinus alpinus & minor & commercial & yes \\
\hline Salvelinus alpinus erythrinus & - & - & - \\
\hline Salvelinus anaktuvukensis & - & - & - \\
\hline Salvelinus andriashevi & - & - & - \\
\hline Salvelinus boganidae & - & - & - \\
\hline Salvelinus colii & - & - & - \\
\hline Salvelinus confluentus & - & - & yes \\
\hline Salvelinus czerskii & - & - & - \\
\hline Salvelinus drjagini & - & - & - \\
\hline Salvelinus elgyticus & - & - & - \\
\hline Salvelinus fimbriatus & - & - & - \\
\hline
\end{tabular}




\begin{tabular}{|l|c|c|c|}
\hline Scientific Name & fishery & aquaculture & gamefish \\
\hline Salvelinus fontinalis & minor & commercial & yes \\
\hline Salvelinus gracillimus & - & - & - \\
\hline Salvelinus grayi & - & - & - \\
\hline Salvelinus inframundus & - & - & - \\
\hline Salvelinus jacuticus & - & - & - \\
\hline Salvelinus japonicus & - & - & - \\
\hline Salvelinus killinensis & - & - & - \\
\hline Salvelinus leucomaenis imbrius & - & - & - \\
\hline Salvelinus leucomaenis leucomaenis & commercial & - & yes \\
\hline Salvelinus leucomaenis pluvius & - & experimental & - \\
\hline Salvelinus levanidovi & - & - & - \\
\hline Salvelinus lonsdalii & - & - & - \\
\hline Salvelinus mallochi & - & - & - \\
\hline Salvelinus malma krascheninnikova & - & - & - \\
\hline Salvelinus malma malma & commercial & - & yes \\
\hline Salvelinus malma miyabei & - & - & - \\
\hline Salvelinus maxillaris & - & - & - \\
\hline Salvelinus murta & - & - & - \\
\hline Salvelinus namaycush & - & - & - \\
\hline Salvelinus neiva & commercial & commercial & yes \\
\hline Salvelinus obtusus & - & - & - \\
\hline Salvelinus perisii & - & - & - \\
\hline Salvelinus profundus & - & - & - \\
\hline Salvelinus scharffi & - & - & - \\
\hline Salvelinus struanensis & - & - & - \\
\hline
\end{tabular}




\begin{tabular}{|l|c|c|c|}
\hline Scientific Name & fishery & aquaculture & gamefish \\
\hline Salvelinus thingvallensis & - & - & - \\
\hline Salvelinus tolmachoffi & - & - & - \\
\hline Salvelinus trevelyani & - & - & - \\
\hline Salvelinus umbla & - & - & - \\
\hline Salvelinus willoughbii & - & - & - \\
\hline Salvelinus youngeri & - & - & - \\
\hline Salvethymus svetovidovi & minor & commercial & yes \\
\hline Stenodus leucichthys & minor & - & yes \\
\hline Thymallus arcticus arcticus & - & - & - \\
\hline Thymallus arcticus baicalensis & - & - & - \\
\hline Thymallus arcticus mertensii & - & - & - \\
\hline Thymallus arcticus pallasii & - & - & - \\
\hline Thymallus brevirostris & - & - & - \\
\hline Thymallus grubii & - & - & - \\
\hline Thymallus nigrescens & commercial & commercial & yes \\
\hline Thymallus thymallus & - & - & - \\
\hline Thymallus yaluensis & & & \\
\hline Adapted from Froese and Pauly. 2005 & & & \\
\hline
\end{tabular}


Table 2. Subspecies of Oncorhynchus mykiss

\begin{tabular}{|l|l|}
\hline O. mykiss stonei & McCloud River redband, Sacramento red band trout \\
\hline O. mykiss gairdneri & Columbia River red band trout \\
\hline O. mykiss aquilarium & Eagle Lake Trout \\
\hline O. mykiss aguabonita & California golden trout \\
\hline O. mykiss whitei & Little Kern golden trout \\
\hline O. mykiss irideus & coastal steelhead, freshwater resident coastal rainbow \\
\hline O. mykiss nelsoni & Rio Santo Domingo, Baja, Mexico \\
\hline O. mykiss newberri & Great Basin Redband Trout \\
\hline O. mykiss gilberti & Kern \& Little Kern golden trout \\
\hline O. mykiss mykiss & Kamchatkan rainbow trout \\
\hline Adapted from Froese and Pauly. 2005 & \\
\hline
\end{tabular}


Table 3. A Survey of Literature of Genetic Analysis in Salmonids

\begin{tabular}{|c|c|c|c|c|}
\hline Species & $\begin{array}{l}\text { type of } \\
\text { population }\end{array}$ & Marker type/method & Use & Reference \\
\hline OC henshawi & $\mathrm{W}$ & microsatellites & genetic variation, population structure & Peacock et al., 2004 \\
\hline $\begin{array}{l}\text { OC, OT, OKi, } \\
\text { OI, OR, SN }\end{array}$ & $\mathrm{w} \& \mathrm{~h}$ & mtDNA gene sequencing & phylogenic relationships of Oncorhynchus & McKay et al., 1996 \\
\hline $\mathrm{OC}$ & $\mathrm{W}$ & mtDNA haplotype & $\begin{array}{l}\text { relationship of mtDNA genotype, nuclear genotype and } \\
\text { phenotype }\end{array}$ & Forbes \& Allendorf, 1991b \\
\hline $\begin{array}{l}\text { OC lesisi X OC } \\
\text { bouvieri }\end{array}$ & $\mathrm{W}$ & $\begin{array}{l}\text { mtDNA, protein } \\
\text { electrophoresis }\end{array}$ & relationship of mtDNA genotype and nuclear genotype & Forbes \& Allendorf, 1991a \\
\hline $\mathrm{OC}$ & $\mathrm{w} \& \mathrm{~h}$ & protein electrophoresis & $\begin{array}{l}\text { examination of population structure; recommendations } \\
\text { on conservation }\end{array}$ & Allendorf \& Leary, 1981 \\
\hline $\mathrm{OC}$ & $\mathrm{W}$ & protein electrophoresis & genetic differentiation, population subdivision & Campton \& Utter, 1987 \\
\hline $\mathrm{OC}$ & $\mathrm{h}$ & protein electrophoresis & linkage of duplicate loci & Allendorf \& Utter, 1976 \\
\hline $\mathrm{OC}$ & $\mathrm{w} \& \mathrm{~h}$ & protein electrophoresis & loss of genetic variation & Allendorf \& Phelps, 1980 \\
\hline $\mathrm{OG}$ & $\mathrm{h}$ & microsatellite, AFLP, PINE & gene-centromere mapping & Linder et al., 2000 \\
\hline $\mathrm{OG}$ & $\mathrm{W}$ & microsatellites & genetic variation & Olsen et al., 1998 \\
\hline $\mathrm{OG}$ & $\mathrm{h}$ & microsatellites & microsatellite mutations & Steinberg et al., 2002 \\
\hline $\mathrm{OG}$ & $\mathrm{h}$ & $\begin{array}{l}\text { microsatellites, RAPD, AFLP, } \\
\text { PINE }\end{array}$ & $\begin{array}{l}\text { analysis of markers for suitability in developing a } \\
\text { linkage map }\end{array}$ & Spruell et al., 1999 \\
\hline $\mathrm{OG}$ & $\mathrm{W}$ & $\begin{array}{l}\text { microsatellites; growth } \\
\text { hormone locus }\end{array}$ & variation of morphological traits & Funk et al., 2005 \\
\hline $\mathrm{OG}$ & $\mathrm{w}$ & mtDNA & genetic differences in time of spawning & Brykov et al., 1999 \\
\hline $\mathrm{OG}$ & $\mathrm{W}$ & protein electrophoresis & $\begin{array}{l}\text { genetic varibility, examination of the neutral mutation- } \\
\text { random drift hypothesis }\end{array}$ & Aspinwall, 1974 \\
\hline $\mathrm{OG}$ & $\mathrm{w}$ & protein electrophoresis & inheritance of 2 co-dominant alleles & Aspinwall, 1973a \\
\hline $\mathrm{OG}$ & $\mathrm{h}$ & protein electrophoresis & linkage mapping & Matsuoka et al., 2004 \\
\hline $\mathrm{OG}$ & $\mathrm{W}$ & protein electrophoresis & population structure & Shaklee et al., 1991 \\
\hline $\mathrm{OG}$ & $\mathrm{h}$ & $\begin{array}{l}\text { selective matings, protein } \\
\text { electrophoresis }\end{array}$ & male fertility & Gharrett \& Shirley, 1985 \\
\hline $\mathrm{OK}$ & $\mathrm{w}$ & minisatellite & population structure $\&$ identification & Taylor et al., 1994 \\
\hline
\end{tabular}




\begin{tabular}{|c|c|c|c|c|}
\hline Species & $\begin{array}{l}\text { type of } \\
\text { population }\end{array}$ & Marker type/method & Use & Reference \\
\hline OK & $\mathrm{W}$ & protein electrophoresis & determination of continent of origin & Winans et al., 1994 \\
\hline $\mathrm{OK}$ & $\mathrm{w}$ & protein electrophoresis & stock identification; genetic variation & Beacham et al., 1987 \\
\hline $\mathrm{OK}$ & $\mathrm{W}$ & protein electrophoresis & stock structure & Wilmot et al., 1994 \\
\hline Oki & $\mathrm{h}$ & selective matings & effects of selection & Hershberger et al., 1990 \\
\hline $\mathrm{OKi}$ & $\mathrm{U}$ & PCR of growth hormone gene & genetic variation & Forbes et al., 1994 \\
\hline $\mathrm{OKi}$ & $\mathrm{U}$ & microsatellites & marker development, cross-species amplification & Smith et al., 1998 \\
\hline OKi & $\mathrm{W}$ & microsatellites & population structure & Small et al., 1998 \\
\hline Oki & $\mathrm{W}$ & microsatellites; 2 MHC exons & stock composition in mixed-stock fishery & Beacham et al., 2001 \\
\hline Oki & $\mathrm{W}$ & minisatellite & stock identification & Beacham et al., 1996 \\
\hline $\mathrm{OM}$ & $\mathrm{h}$ & selective matings & $\begin{array}{l}\text { abnormal body curvatures, egg } \& \text { fry mortality due to } \\
\text { inbreeding } \& \text { high incubation temperature }\end{array}$ & Aulstad \& Kittelsen, 1971 \\
\hline OM & $\mathrm{h}$ & AFLP & QTL for C. shasta resistance & Nichols et al., 2003 \\
\hline $\mathrm{OM}$ & $\mathrm{N} / \mathrm{A}$ & BAC library & gene duplication, mapping & Palti et al., 2004 \\
\hline $\mathrm{OM}$ & $\mathrm{w} \& \mathrm{~h}$ & chromosome evaluation & chromosomal differences & Thorgaard, 1983a \\
\hline $\mathrm{OM}$ & $\mathrm{h}$ & chromosome evaluation & chromosomal structural changes, tetraploidy & Delaney \& Bloom, 1984 \\
\hline $\mathrm{OM}$ & $\mathrm{h}$ & chromosome evaluation & natural occurance of triploidy & Thorgaard et al., 1979 \\
\hline $\mathrm{OM}(\mathrm{s})$ & $\mathrm{W}$ & chromosome evaluation & chromosomal differnces between populations & Thorgaard, 1977 \\
\hline $\mathrm{OM}, \mathrm{OC}$ & $\mathrm{h}$ & $\begin{array}{l}\text { DNA fingerprinting via } \\
\text { oligonucleotide probes }\end{array}$ & genetic variability among strains & Palti et al., 1996 \\
\hline $\begin{array}{l}\text { OM, OC lewisi, } \\
\text { OC bouvieri }\end{array}$ & $\mathrm{h}$ & $\begin{array}{l}\text { DNA fingerprinting via } \\
\text { oligonucleotide probes }\end{array}$ & genetic variability between species & Palti et al., 1997 \\
\hline $\mathrm{OM}$ & $\mathrm{w} \& \mathrm{~h}$ & fin removal & determination of optimal time of release & Wagner et al., 1963 \\
\hline $\mathrm{OM}(\mathrm{s})$ & $\mathrm{w} \& \mathrm{~h}$ & gene frequency analysis & breeding structure of populations & Utter et al., 1977 \\
\hline $\mathrm{OM}$ & $\mathrm{w} \& \mathrm{~h}$ & $\begin{array}{l}\text { glycerophosphate } \\
\text { dehydrogenase alleles }\end{array}$ & interaction between wild \& hatchery steelhead & Crawford, year? \\
\hline OM, SS, SA & $\begin{array}{l}\mathrm{h} \text { (mapped } \\
\text { families) }\end{array}$ & GNRH3 gene & sequence divergence & Leder et al., 2004 \\
\hline $\mathrm{OM}$ & $\mathrm{h}$ & maintenance of separate stocks & $\begin{array}{l}\text { influence of strain on body composition (protein, } \\
\text { moisture, ash) \& growth }\end{array}$ & Reinitz et al., 1979 \\
\hline $\mathrm{OM}$ & $\mathrm{w} \& \mathrm{~h}$ & maintenance of separate stocks & stress response & Woodward \& Strange, 1987 \\
\hline
\end{tabular}




\begin{tabular}{|c|c|c|c|c|}
\hline Species & $\begin{array}{l}\text { type of } \\
\text { population }\end{array}$ & Marker type/method & Use & Reference \\
\hline $\mathrm{OM}$ & $\mathrm{h}$ & $\begin{array}{l}\text { meristic characgters, protein } \\
\text { electrophoresis }\end{array}$ & developmental rate, developmental stability & Ferguson et al., 1988b \\
\hline $\mathrm{OM}$ & $\mathrm{w} \& \mathrm{~h}$ & meristic characters & differences in life histories of wild $\&$ hatchery fishes & Leider et al., 1986 \\
\hline $\mathrm{OM}$ & $\mathrm{w}$ & $\begin{array}{l}\text { meristic characters, protein } \\
\text { electrophoresis }\end{array}$ & genetic comparison of stream populations & Northcote et al., 1970 \\
\hline $\begin{array}{l}\text { OM, OC } \\
\text { seleniris, OC } \\
\text { henshawi }\end{array}$ & $\mathrm{w} \& \mathrm{~h}$ & $\begin{array}{l}\text { meristic characters, protein } \\
\text { electrophoresis }\end{array}$ & hybridization, introgression & Busack et al., 1981 \\
\hline $\begin{array}{l}\text { OM aquilarum, } \\
\text { OC }\end{array}$ & $\mathrm{w} \& \mathrm{~h}$ & $\begin{array}{l}\text { meristic characters, protein } \\
\text { electrophoresis, chromosome } \\
\text { evaluation }\end{array}$ & identification of Eagle Lake trout as rainbow trout & Busack et al., 1980 \\
\hline $\mathrm{OM}$ & $\mathrm{h}$ & MHC gene & gene duplication, mapping & Phillips et al., 2003 \\
\hline $\mathrm{OM}$ & $\mathrm{h}$ & $\begin{array}{l}\text { microsatellies, protein } \\
\text { electrophoresis }\end{array}$ & heterozygosity-fitness correlations & Thelen \& Allendorf, 2001 \\
\hline $\mathrm{OM}$ & $\mathrm{h}$ & microsatellite & development of linkage map & Sakamoto et al., 2000 \\
\hline $\mathrm{OM}$ & $\mathrm{h}$ & microsatellite & growth \& survival & Herbinger et al, 1995 \\
\hline OM & $\mathrm{h}$ & microsatellite & identification of individuals to determine pedigree & Chevassus et al., 2002 \\
\hline $\mathrm{OM}$ & $\mathrm{h}$ & microsatellite & QTL for IHN virus resistance & Khoo et al., 2004 \\
\hline $\mathrm{OM}$ & $\mathrm{h}$ & microsatellite, AFLP & mapping of dominant albino locus & Nakamura et al., 2001 \\
\hline $\mathrm{OM}$ & $\mathrm{h}$ & microsatellites & $\begin{array}{l}\text { characterization of markers from EST vs. genomic } \\
\text { libraries }\end{array}$ & Coulibaly et al., 2005 \\
\hline $\mathrm{OM}$ & $\mathrm{N} / \mathrm{A}$ & microsatellites & development of linkage map & Ozaki et al., 2003 \\
\hline $\mathrm{OM}$ & $\mathrm{N} / \mathrm{A}$ & microsatellites & development of linkage map & Palti et al., 2002a \\
\hline OM & $\mathrm{w}$ & microsatellites & differentation of populations & O'Connell et al., 1997 \\
\hline $\mathrm{OM}$ & $\mathrm{h}$ & microsatellites & epistasis of QTL for survival and morphological traits & Perry et al., 2003 \\
\hline OM & $\mathrm{N} / \mathrm{A}$ & microsatellites & $\begin{array}{l}\text { ESTs containing microsatellites, cross-species } \\
\text { amplification }\end{array}$ & Rexroad et al., 2005 \\
\hline $\mathrm{OM}$ & $\mathrm{h}$ & microsatellites & $\begin{array}{l}\text { feed conversion, specific growth, response to IHN } \\
\text { virus, diversity }\end{array}$ & Overturf et al., 2003 \\
\hline OM & $\mathrm{W}$ & microsatellites & genetic divergence & Narum et al., 2005 \\
\hline OM & $\mathrm{h}$ & microsatellites & genetic diversity & Ward et al., 2003 \\
\hline
\end{tabular}




\begin{tabular}{|c|c|c|c|c|}
\hline Species & $\begin{array}{l}\text { type of } \\
\text { population }\end{array}$ & Marker type/method & Use & Reference \\
\hline $\mathrm{OM}$ & $\mathrm{h}$ & microsatellites & genetic variation & Silverstein et al., 2004 \\
\hline $\mathrm{OM}$ & $\mathrm{h}$ & microsatellites & growth \& precocious puberty; QTL for body mass & Martyniuk et al., 2003 \\
\hline $\mathrm{OM}$ & $\mathrm{w} \& \mathrm{~h}$ & microsatellites & $\begin{array}{l}\text { identification of a null allele in microsatellite } \\
\text { OMY3DIAS }\end{array}$ & Holm et al., 2001 \\
\hline $\mathrm{OM}$ & $\mathrm{N} / \mathrm{A}$ & microsatellites & marker development, cross-species amplification & Morris et al., 1996 \\
\hline $\mathrm{OM}$ & $\mathrm{N} / \mathrm{A}$ & microsatellites & marker development, cross-species amplification & Rexroad et al., 1998 \\
\hline $\mathrm{OM}$ & $\mathrm{N} / \mathrm{A}$ & microsatellites & marker development, cross-species amplification & Rexroad et al., 2002b \\
\hline $\mathrm{OM}$ & $\mathrm{N} / \mathrm{A}$ & microsatellites & marker development, cross-species amplification & Rexroad et al., 2002c \\
\hline $\mathrm{OM}$ & $\mathrm{N} / \mathrm{A}$ & microsatellites & marker development, cross-species amplification & Rodriguez et al., 2003 \\
\hline $\mathrm{OM}$ & $\mathrm{N} / \mathrm{A}$ & microsatellites & $\begin{array}{l}\text { marker development, cross-species amplification, } \\
\text { suitability for linkage mapping }\end{array}$ & Rexroad et al., 2002a \\
\hline $\mathrm{OM}$ & N/A & microsatellites & marker development, suitability for linkage mapping & Rexroad et al., 2003 \\
\hline $\mathrm{OM}$ & N/A & microsatellites & $\begin{array}{l}\text { marker development; suitability for genetic \& } \\
\text { population studies }\end{array}$ & Sakamoto et al., 1994 \\
\hline $\mathrm{OM}$ & N/A & microsatellites & $\begin{array}{l}\text { marker loci duplication, application of markers to other } \\
\text { Salmonids }\end{array}$ & Palti et al., 2002b \\
\hline $\mathrm{OM}$ & $\mathrm{h}$ & microsatellites & multiplexing of microsatellite reactions & Fishback et al., 1999 \\
\hline $\mathrm{OM}$ & $\mathrm{h}$ & microsatellites & parentage determination & Estoup et al., 1998a \\
\hline $\mathrm{OM}$ & $\mathrm{h}$ & microsatellites & parentage determination & O'Reilly et al., 1998 \\
\hline $\mathrm{OM}$ & $\mathrm{h}$ & microsatellites & pedigrees for heritability estimates & Fishback et al., 2002 \\
\hline $\mathrm{OM}$ & $\mathrm{h}$ & microsatellites & QTL for IPN virus & Ozaki et al., 2001 \\
\hline $\mathrm{OM}$ & $\mathrm{h}$ & microsatellites & QTL for spawning date $\&$ body weight & O'Malley et al., 2002 \\
\hline $\mathrm{OM}$ & $\mathrm{w} \& \mathrm{~h}$ & microsatellites & QTL for spawning time & Sakamoto et al., 1999 \\
\hline $\mathrm{OM}$ & $\mathrm{w} \& \mathrm{~h}$ & microsatellites & QTL for upper temperature tolerance \& growth & Perry et al., 2005 \\
\hline $\mathrm{OM}$ & $\mathrm{h}$ & microsatellites & QTL of upper temperature tolererance & Perry et al., 2001 \\
\hline $\mathrm{OM}$ & $\mathrm{w} \& \mathrm{~h}$ & microsatellites & QTL-temperature tolerance & Danzmann et al., 1999 \\
\hline $\mathrm{OM}$ & $\mathrm{h}$ & microsatellites & QTL-time of spawning & Fishback et al., 2000 \\
\hline $\mathrm{OM}$ & $\mathrm{h}$ & microsatellites & relatedness determination, broodstock selection & McDonald et al., 2004 \\
\hline $\mathrm{OM}$ & $\mathrm{w}$ & microsatellites & reproductive success, mating system & Seamons et al., 2004 \\
\hline $\mathrm{OM}$ & & microsatellites & genetic comparison & McConnell et al., 1995c \\
\hline $\mathrm{OM}(\mathrm{s})$ & $\mathrm{W}$ & microsatellites & changes in population structure over 40 years & Health et al., 2002 \\
\hline
\end{tabular}




\begin{tabular}{|c|c|c|c|c|}
\hline Species & $\begin{array}{l}\text { type of } \\
\text { population }\end{array}$ & Marker type/method & Use & Reference \\
\hline OM stonei & $\mathrm{W}$ & microsatellites & population structure of relic population & Nielsen JL et al., 1999 \\
\hline $\mathrm{OM}(\mathrm{s})$ & $\mathrm{w} \& \mathrm{~h}$ & microsatellites & reproductive success of wild vs stocked hatchery fishes & McLean et al., 2003 \\
\hline $\mathrm{OM}(\mathrm{s})$ & $\mathrm{w} \& \mathrm{~h}$ & microsatellites & reproductive success of wild vs stocked hatchery fishes & McLean et al., 2004 \\
\hline OM, SA & $\mathrm{h}$ & microsatellites & QTL for upper temperatuer tolerance & Somorjai et al., 2003 \\
\hline $\begin{array}{l}\text { OM, SA, SS, } \\
\text { ST, SN }\end{array}$ & N/A & microsatellites & mapping of sex-linkage groups & Woram et al., 2003b \\
\hline OM, SS, SA & $\mathrm{h}$ & microsatellites & QTL for body weight \& condition factor & Reid et al., 2005 \\
\hline OM, OC & $\mathrm{w}$ & $\begin{array}{l}\text { microsatellites (SSRs using } \\
\text { spPCR }\end{array}$ & identification of subspecies & Ostberg \& Rodriguez, 2002 \\
\hline $\mathrm{OM}$ & $\mathrm{h}$ & microsatellites, AFLP & QTL for NK cell-like activity & Zimmerman et al., 2004 \\
\hline $\mathrm{OM}(\mathrm{s} \mathrm{X} \mathrm{r})$ & $\mathrm{h}$ & microsatellites, AFLP, & QTL for IHN virus resistance & Rodriguez et al., 2004 \\
\hline $\mathrm{OM}$ & $\mathrm{h}$ & $\begin{array}{l}\text { microsatellites, AFLP, PCR of } \\
\text { type I loci, }\end{array}$ & development of linkage map & Nichols et al., 2002 \\
\hline $\mathrm{OM}$ & $\mathrm{h}$ & $\begin{array}{l}\text { microsatellites, AFLP, PCR of } \\
\text { type I loci, }\end{array}$ & development of linkage map & Nichols et al., 2002 \\
\hline $\mathrm{OM}$ & $\mathrm{h}$ & $\begin{array}{l}\text { microsatellites, AFLP, RAPD, } \\
\text { SINE }\end{array}$ & development of linkage map & Young et al., 1998 \\
\hline $\mathrm{OM}$ & $\mathrm{h}$ & $\begin{array}{l}\text { microsatellites, protein } \\
\text { electrophoresis, RAPD }\end{array}$ & QTL for upper temperature tolerance & Jackson et al., 1998 \\
\hline $\mathrm{OM}$ & $\mathrm{h}$ & $\begin{array}{l}\text { microsatellites, RFLP of } \\
\text { mtDNA, allozymes }\end{array}$ & comparison of marker types & Ferguson \& Danzmann, 1998 \\
\hline $\mathrm{OM}$ & $\mathrm{w} \& \mathrm{~h}$ & minisatellite & genetic variation & Taylor et al., 1995 \\
\hline $\mathrm{OM}$ & $\mathrm{h}$ & mtDNA & genetic variation & Sajedi et al., 2003 \\
\hline $\mathrm{OM}$ & $\mathrm{W}$ & mtDNA & identification of redband and coastal trout & Williams et al., 2000 \\
\hline $\mathrm{OM}$ & $\mathrm{w}$ & mtDNA & population structure & Dueck \& Danzmann, 1996 \\
\hline $\mathrm{OM}$ & $\mathrm{w} \& \mathrm{~h}$ & mtDNA & population structure & Rossi et al., 2004 \\
\hline $\mathrm{OM}$ & $\mathrm{w} \& \mathrm{~h}$ & mtDNA (RFLP) & $\begin{array}{l}\text { genetic variation between hatchery sources and a } \\
\text { naturalized population }\end{array}$ & Danzmann et al., 1993 \\
\hline $\mathrm{OM}$ & $\mathrm{h}$ & mtDNA (RFLP) & maternal genetic contribution to date of spawning & Danzmann et al., 1994 \\
\hline $\mathrm{OM}(\mathrm{s} \& \mathrm{r}), \mathrm{OC}$ & $\mathrm{W}$ & mtDNA (RFLP) & comparison of species and populations & Wilson et al., 1985 \\
\hline
\end{tabular}




\begin{tabular}{|c|c|c|c|c|}
\hline Species & $\begin{array}{l}\text { type of } \\
\text { population }\end{array}$ & Marker type/method & Use & Reference \\
\hline $\mathrm{OM}$ & unspecified & mtDNA (sequence) & comparison of sequence to other species & Digby et al., 1992 \\
\hline $\mathrm{OM}$ & $\mathrm{N} / \mathrm{A}$ & $\begin{array}{l}\text { mtDNA, protein } \\
\text { electrophoresis }\end{array}$ & phylogenic relationships of Oncorhynchus & Utter \& Allendorf, 1994 \\
\hline $\begin{array}{l}\text { OM, OC lewisi, } \\
\text { hybrids }\end{array}$ & $\mathrm{w}$ & mtDNA, RFLP & incidence of hybridization \& introgression & Rubridge et al., 2001 \\
\hline $\mathrm{OM}$ & $\mathrm{w} \& \mathrm{~h}$ & mtDNA, scnDNA, SSCP & $\begin{array}{l}\text { assess genetic structure and relatedness; comparison of } \\
\text { mtDNA \& scnDNA diversity }\end{array}$ & Bagley \& Gall, 1998 \\
\hline $\mathrm{OM}$ & $\mathrm{w}$ & N/A (review) & $\begin{array}{l}\text { specific attributes of different strains (adaptation to } \\
\text { alkaline waters, disease resistance, reduced migration) }\end{array}$ & Kinunen \& Moring \\
\hline $\begin{array}{l}\text { OM irideus, OC } \\
\text { clarki }\end{array}$ & $\mathrm{w} \& \mathrm{~h}$ & $\begin{array}{l}\text { PCR \& RFLPof protein-coding } \\
\text { loci; RFLP of mtDNA }\end{array}$ & frequency of hybridization & Docker et al., 2003 \\
\hline $\mathrm{OM}$ & N/A & PCR of 5S rDNA & product identity & Carrera et al., 2000a \\
\hline $\mathrm{OM}$ & N/A & PCR of mtDNA gene & product identity & Carrera et al., 1998 \\
\hline OM, SS & N/A & PCR of p53 gene & product identity & Carrera et al., $2000 \mathrm{~b}$ \\
\hline $\mathrm{OM}, \mathrm{SS}$ & N/A & PCR-RFLP of COII gene & product identity & Carrera et al., 1999a \\
\hline OM, SS & N/A & PCR-RFLP of mtDNA gene & product identity & Carrera et al., 1999b \\
\hline $\begin{array}{l}\text { OM, OC lewisi, } \\
\text { OC Bouvieri }\end{array}$ & $\mathrm{w}$ & PINE & hybridization, introgression & Hitt et al., 2003 \\
\hline OM, ST & $\mathrm{h}$ & ploidy (triploid vs. diploid) & genetic differences in growth & Bonnet et al., 1999 \\
\hline $\mathrm{OM}$ & $\mathrm{w} \& \mathrm{~h}$ & protein electrophoresis & comparison of wild \& hatchery stocks & Campton \& Johnson, 1985 \\
\hline $\mathrm{OM}$ & $\mathrm{h}$ & protein electrophoresis & developmental \& survival rate & Ferguson et al., 1988b \\
\hline $\mathrm{OM}$ & $\mathrm{h}$ & protein electrophoresis & developmental stablity $\&$ heterozygosity & Leary et al., 1983 \\
\hline $\mathrm{OM}$ & $\mathrm{h}$ & protein electrophoresis & developmental stablity \& heterozygosity & Leary et al., $1985 \mathrm{a}$ \\
\hline $\mathrm{OM}$ & $\mathrm{h}$ & protein electrophoresis & developmental stablity \& heterozygosity & Leary et al., $1987 \mathrm{~b}$ \\
\hline $\mathrm{OM}$ & $\mathrm{w} \& \mathrm{~h}$ & protein electrophoresis & $\begin{array}{l}\text { differential reproductive success of wild } \& \text { hatchery } \\
\text { fishes }\end{array}$ & Leider et al., 1990 \\
\hline $\mathrm{OM}$ & $\mathrm{W}$ & protein electrophoresis & disease resistance & Ferguson \& Drahuschak, 1990 \\
\hline $\mathrm{OM}$ & $\mathrm{h}$ & protein electrophoresis & disomic vs. tetrasomic inheritance of allozymes & Allendorf \& Utter, 1973 \\
\hline $\mathrm{OM}$ & $\mathrm{w}$ & protein electrophoresis & $\begin{array}{l}\text { distribution of LDH-B gene in anadramous \& resident } \\
\text { populataions }\end{array}$ & Huzyk \& Tsuyuki, 1974 \\
\hline
\end{tabular}




\begin{tabular}{|c|c|c|c|c|}
\hline Species & $\begin{array}{l}\text { type of } \\
\text { population }\end{array}$ & Marker type/method & Use & Reference \\
\hline $\mathrm{OM}$ & $\mathrm{h}$ & protein electrophoresis & $\begin{array}{l}\text { effects of genotype } \& \text { temperature on hatching } \& \\
\text { survival }\end{array}$ & Danzmann, 1988a \\
\hline $\mathrm{OM}$ & $\mathrm{h}$ & protein electrophoresis & gene-centromere mapping & Allendorf et al., 1986 \\
\hline $\mathrm{OM}$ & $\mathrm{h}$ & protein electrophoresis & gene-centromere mapping & Thorgaard, $1983 \mathrm{c}$ \\
\hline $\mathrm{OM}$ & $\mathrm{w} \& \mathrm{~h}$ & protein electrophoresis & genetic adaptation to higher temperature & Fisher et al, 1982 \\
\hline $\mathrm{OM}$ & $\mathrm{h}$ & protein electrophoresis & genetic analysis of androgenic individuals & Scheerer et al., 1991 \\
\hline OM & $\mathrm{W}$ & protein electrophoresis & genetic comparison of naturalized populations & Krueger \& May, 1987b \\
\hline OM & $\mathrm{w} \& \mathrm{~h}$ & protein electrophoresis & genetic divergence & Okazaki, 1984 \\
\hline $\mathrm{OM}$ & $\mathrm{h}$ & protein electrophoresis & genetic identification & Thompson, 1985 \\
\hline $\mathrm{OM}$ & $\mathrm{h}$ & protein electrophoresis & genetic variation & Leary et al., 1989 \\
\hline $\mathrm{OM}$ & $\mathrm{h}$ & protein electrophoresis & genetic variation, egg size $\&$ developmental rate & Danzman et al., 1989 \\
\hline $\mathrm{OM}$ & $\mathrm{h}$ & protein electrophoresis & heterozygosity \& rate of development & Danzmann et al., 1985a \\
\hline $\mathrm{OM}$ & $\mathrm{h}$ & protein electrophoresis & heterozygosity \& rate of development & Danzman et al, 1986 \\
\hline $\mathrm{OM}$ & $\mathrm{h}$ & protein electrophoresis & linkage and segregation of loci & May et al., 1982 \\
\hline $\mathrm{OM}$ & $\mathrm{h}$ & protein electrophoresis & $\begin{array}{l}\text { response of hetero- and homozygotes to differing } \\
\text { rearing temperatures }\end{array}$ & Danzmann, 1988b \\
\hline $\mathrm{OM}$ & $\mathrm{w} \& \mathrm{~h}$ & protein electrophoresis & review; genetic population structure & Allendorf \& Phelps, 1981 \\
\hline $\mathrm{OM}$ & $\mathrm{h}$ & protein electrophoresis & sex-linkage of loci & Allendorf et al., 1994 \\
\hline $\mathrm{OM}$ & $\mathrm{w} \& \mathrm{~h}$ & protein electrophoresis & stock structure & Milner et al.,. 1979 \\
\hline $\mathrm{OM}$ & $\mathrm{h}$ & protein electrophoresis & timing of gene expression & Danzmann et al., $1985 \mathrm{~b}$ \\
\hline $\mathrm{OM}$ & $\mathrm{h}$ & protein electrophoresis & verification of unlinked, duplicate loci, tetraploidy & Gall,\& Bentley, 1982 \\
\hline $\mathrm{OM}$ & $\mathrm{h}$ & protein electrophoresis & genetic variability & Guyomard, 1981 \\
\hline $\mathrm{OM}(\mathrm{s} \& \mathrm{r})$ & $\mathrm{U}$ & protein electrophoresis & genetic variation & Cederbaum \& Yoshida, 1972 \\
\hline $\mathrm{OM}(\mathrm{s})$ & $\mathrm{W}$ & protein electrophoresis & comparison of summer \& winter populations & Chilcote et al., 1980 \\
\hline $\mathrm{OM}(\mathrm{s})$ & $\mathrm{w}$ & protein electrophoresis & genetic variation & Riesenbichler \& Phelps, 1989 \\
\hline $\mathrm{OM}(\mathrm{s})$ & $\mathrm{W}$ & protein electrophoresis & genetic variation & Reisenbichler et al., 1992 \\
\hline $\mathrm{OM}(\mathrm{s})$ & $\mathrm{W}$ & protein electrophoresis & genetic variation & Parkinson, 1984 \\
\hline $\mathrm{OM}(\mathrm{s})$ & $\mathrm{W}$ & protein electrophoresis & reproductive success of wild vs hatchery & Chilcote et al., 1986 \\
\hline $\mathrm{OM}(\mathrm{s})$ & $\mathrm{W}$ & protein electrophoresis & stock structure of mixed fishery & Milner, 1977 \\
\hline OM London & $\mathrm{h}$ & protein electrophoresis & stock structure & Gregg, 2001 \\
\hline
\end{tabular}




\begin{tabular}{|c|c|c|c|c|}
\hline Species & $\begin{array}{l}\text { type of } \\
\text { population }\end{array}$ & Marker type/method & Use & Reference \\
\hline $\mathrm{OM}(\mathrm{s})$ & $\mathrm{w} \& \mathrm{~h}$ & protein electrophoresis & reproductive success & Campton,1991 \\
\hline $\mathrm{OM}(\mathrm{s})$ & $\mathrm{w} \& \mathrm{~h}$ & protein electrophoresis & reproductive success & Chilcote et al., 1991 \\
\hline $\mathrm{OM}, \mathrm{OC}$ & $\mathrm{w}$ & protein electrophoresis & $\begin{array}{l}\text { failure of PGI in distinction of rainbow and cutthroat } \\
\text { trout }\end{array}$ & Allendorf et al., 1978 \\
\hline OM, OKi, ON & $\mathrm{h}$ & protein electrophoresis & variation in gene loci & Utter \& Hodgins, 1972 \\
\hline $\begin{array}{l}\text { OM, } \\
\text { Oncorhynchus } \\
\text { sp. }\end{array}$ & $\mathrm{w} \& \mathrm{~h}$ & protein electrophoresis & genetic variation & Utter, 1971 \\
\hline OM, OT & $\mathrm{w} \& \mathrm{~h}$ & protein electrophoresis & effective population size & Bartley et al., 1992a \\
\hline OM, OT & $\mathrm{w} \& \mathrm{~h}$ & protein electrophoresis & stock identification & Milner et al., 1980 \\
\hline $\mathrm{OM}, \mathrm{SC}$ & $\mathrm{w} \& \mathrm{~h}$ & protein electrophoresis & identification of subspecies, genetic divergence & Leary et al., 1987a \\
\hline $\begin{array}{l}\text { OM, SC lewisi, } \\
\text { SF }\end{array}$ & $\mathrm{w} \& \mathrm{~h}$ & protein electrophoresis & developmental stablity \& heterozygosity & Leary et al., 1984 \\
\hline $\begin{array}{l}\mathrm{OM}, \mathrm{SC}, \mathrm{OM} x \\
\text { SC hybrids }\end{array}$ & $\mathrm{w} \& \mathrm{~h}$ & protein electrophoresis & identification of rainbow, cutthroat, and their hybrids & Reinitz et al., 1977 \\
\hline $\mathrm{OM}, \mathrm{SF}$ & $\mathrm{w} \& \mathrm{~h}$ & protein electrophoresis & number of genes \& alleles of LDH & Bailey et al., 1976 \\
\hline $\begin{array}{l}\text { OM, SS, ST, } \\
\text { ON }\end{array}$ & $\mathrm{N} / \mathrm{A}$ & protein electrophoresis & genetic comparison of species & Ryman, 1983 \\
\hline $\mathrm{OM}, \mathrm{ST}$ & $\mathrm{w} \& \mathrm{~h}$ & protein electrophoresis & comparison of hatchery and source stocks & Ferguson et al., 1991 \\
\hline $\begin{array}{l}\text { OM, ST, } 3 \\
\text { interspecific } \\
\text { hybrid } \\
\text { Salmonids }\end{array}$ & $\mathrm{h}$ & protein electrophoresis & $\begin{array}{l}\text { conservation of linkage relationships among salmonid } \\
\text { species }\end{array}$ & Johnson et al., 1987 \\
\hline OM, ST, SS & $\mathrm{w} \& \mathrm{~h}$ & protein electrophoresis & genetic variation; taxonomy & Ferguson \& Fleming, 1983 \\
\hline $\mathrm{OM}(\mathrm{s})$ & $\mathrm{w} \& \mathrm{~h}$ & quantitative scale analysis & population structure & Daugherty et al, 2003 \\
\hline $\mathrm{OM}$ & $\mathrm{w} \& \mathrm{~h}$ & RAPD-SSCP & population structure & Bagley et al., 1997 \\
\hline $\mathrm{OM}, \mathrm{OC}$ & $\mathrm{h}$ & RFLP & IHN virus resistance $\&$ susceptibility & Palti et al., 1999 \\
\hline $\mathrm{OM}$ & $\mathrm{h}$ & RFLP (VNTR probes) & verification of homozygous, clonal lines & Young et al., 1996 \\
\hline $\mathrm{OM}$ & $\mathrm{w} \& \mathrm{~h}$ & $\begin{array}{l}\text { RFLP of mtDNA; protein } \\
\text { electrophoresis }\end{array}$ & genetic variation & Ferguson A et al., 1993 \\
\hline $\mathrm{OM}(\mathrm{s})$ & $\mathrm{h}$ & scale characteristics & heritability of age at maturity & Tipping, 1991 \\
\hline
\end{tabular}




\begin{tabular}{|c|c|c|c|c|}
\hline Species & $\begin{array}{l}\text { type of } \\
\text { population }\end{array}$ & Marker type/method & Use & Reference \\
\hline $\mathrm{OM}(\mathrm{s})$ & $\mathrm{w} \& \mathrm{~h}$ & scale characteristics & identification of wild \& hatchery & Seelbach \& Whelan \\
\hline $\mathrm{OM}(\mathrm{s})$ & $\mathrm{h}$ & selective matings & selection for early spawning & Millenbach, 1973 \\
\hline $\mathrm{OM}(\mathrm{s})$ & $\mathrm{W}$ & selective matings & selection for time of return $\&$ body size & Garrison, 1977 \\
\hline $\mathrm{OM}, \mathrm{OC}$ & $\mathrm{W}$ & SINE, minisatellite & hybridization between two species & Kanda, 2002a \\
\hline $\mathrm{OM}$ & $\mathrm{h}$ & selective matings & age \& weight at sexual maturity & Crandall \& Gall, 1993b \\
\hline $\mathrm{OM}$ & $\mathrm{h}$ & selective matings & body weight \& sexual maturity & Crandall \& Gall, 1993a \\
\hline $\mathrm{OM}$ & $\mathrm{h}$ & selective matings & disease resistance & Bartholomew et al., 2001 \\
\hline $\mathrm{OM}$ & $\mathrm{h}$ & selective matings & disease resistance & Ibarra, 1994 \\
\hline $\mathrm{OM}$ & $\mathrm{h}$ & selective matings & effect of inbreeding on body weight & Pante et al., 2001a \\
\hline $\mathrm{OM}$ & $\mathrm{h}$ & selective matings & effects of genotype $\&$ temperature on growth \& size & Wanglia \& Dick, 1988 \\
\hline $\mathrm{OM}$ & $\mathrm{h}$ & selective matings & effects of inbreeding on growth $\&$ reproductive traits & Su et al., 1996a \\
\hline $\mathrm{OM}$ & $\mathrm{h}$ & selective matings & effects of inbreeding on growth \& survival & Gjerde et al., 1983 \\
\hline $\mathrm{OM}$ & $\mathrm{h}$ & selective matings & genetic influence on length $\&$ weight & Gunnes et al., 1981 \\
\hline $\mathrm{OM}$ & $\mathrm{h}$ & selective matings & genetic variance components & Pante et al., 2002 \\
\hline $\mathrm{OM}$ & $\mathrm{h}$ & selective matings & genetic variation in reproductive traits & Gall, 1975 \\
\hline $\mathrm{OM}$ & $\mathrm{w} \& \mathrm{~h}$ & selective matings & growth & Tymchuk et al., 2005 \\
\hline $\mathrm{OM}$ & $\mathrm{w} \& \mathrm{~h}$ & selective matings & growth and survival & Ayles, 1975 \\
\hline $\mathrm{OM}$ & $\mathrm{w} \& \mathrm{~h}$ & selective matings & growth, feed coversion & Fessler, 1977 \\
\hline $\mathrm{OM}$ & $\mathrm{w} \& \mathrm{~h}$ & selective matings & $\begin{array}{l}\text { heat tolerande \& growth characteristics in selected \& } \\
\text { non-selected stocks }\end{array}$ & Molony et al., 2004 \\
\hline $\mathrm{OM}$ & $\mathrm{h}$ & selective matings & heritability of age at spawning & Gall, 1988 \\
\hline $\mathrm{OM}$ & $\mathrm{h}$ & selective matings & interaction of strain \& environment on growth & Klupp et al., 1978 \\
\hline $\mathrm{OM}$ & $\mathrm{h}$ & selective matings & levels of inbreeding & Pante et al., 2001b \\
\hline $\mathrm{OM}$ & $\begin{array}{l}\text { w, h, w x h } \\
\text { hybrid }\end{array}$ & selective matings & lipid \& dry matter content & Ayles, 1979 \\
\hline $\mathrm{OM}$ & $\mathrm{h}$ & selective matings & potential to select improved appearance & Kause et al., 2004 \\
\hline $\mathrm{OM}$ & $\mathrm{h}$ & selective matings & reproductive performance & Gall \& Gross, 1978 \\
\hline $\mathrm{OM}$ & $\mathrm{h}$ & selective matings & selection for early spawning & Siitonen \& Gall, 1989 \\
\hline $\mathrm{OM}$ & $\mathrm{h}$ & selective matings & variation in body weight & Su et al, 1996b \\
\hline $\mathrm{OM}$ & $\mathrm{h}$ & selective matings & variation in female reproductive traits & Su et al., 1997 \\
\hline
\end{tabular}




\begin{tabular}{|c|c|c|c|c|}
\hline Species & $\begin{array}{l}\text { type of } \\
\text { population }\end{array}$ & Marker type/method & Use & Reference \\
\hline OM, SS & $\mathrm{w} \& \mathrm{~h}$ & selective matings & heritabilities of carcass traits & Gjerde et al., 1984 \\
\hline $\begin{array}{l}\text { OM, ST X SN } \\
\text { hybrids }\end{array}$ & $\mathrm{h}$ & $\begin{array}{l}\text { selective matings, } \\
\text { hybridization of species }\end{array}$ & susceptibility to IHN virus & LaPatra et al., 1996 \\
\hline $\mathrm{OM}$ & $\mathrm{h}$ & $\begin{array}{l}\text { selective matings, protein } \\
\text { electrophoresis }\end{array}$ & effects of stocking density on growth & Bagley et al., 1994 \\
\hline $\mathrm{OM}$ & $\mathrm{h}$ & $\begin{array}{l}\text { selective matings, protein } \\
\text { electrophoresis }\end{array}$ & genetic variability differences among mating strategies & Gile \& Ferguson, 1990 \\
\hline $\mathrm{OM}$ & $\mathrm{w} \& \mathrm{~h}$ & $\begin{array}{l}\text { selective matings, protein } \\
\text { electrophoresis }\end{array}$ & growth \& survival & Reisenbichler, 1977 \\
\hline $\begin{array}{l}\text { OM X OC } \\
\text { hybrids }\end{array}$ & $\mathrm{h}$ & $\mathrm{SSCP}$ & IHN virus resistance \& susceptibility & Palti et al., 2001 \\
\hline $\mathrm{OM}$ & $\begin{array}{l}\mathrm{h} \text { (reference } \\
\text { family) }\end{array}$ & $\mathrm{SSCP}$, microsatellite & gene linkages & Gharbi et al., 2004 \\
\hline ON & $\mathrm{w}$ & microsatellites & identification of individuals to source population & Beacham et al., 2002 \\
\hline ON & $\mathrm{w}$ & microsatellites & genetic divergence \& variation, population bottleneck & Ramstad et al., 2004 \\
\hline ON & $\mathrm{w}$ & microsatellites & marker development, cross-species amplification & Scribner et al., 1996b \\
\hline ON (Walbaum) & $\mathrm{w}$ & microsatellites & population structure & Withler et al., 2000 \\
\hline ON (Walbaum) & $\mathrm{w}$ & microsatellites & stock identification & Beacham et al., 2000a \\
\hline ON (Walbaum) & $\mathrm{w}$ & microsatellites & stock identification & Beacham et al., 2000b \\
\hline $\mathrm{ON}$ & $\mathrm{W}$ & minisatellite & stock identification & Beacham et al., 1995 \\
\hline ON & $\mathrm{w}$ & minisatelllites, mtDNA & genetic variation & Taylor et al., 1996 \\
\hline ON & $\mathrm{W}$ & mtDNA (PCR) & genetic variation, stock structure & Bickham et al., 1995 \\
\hline ON & $\mathrm{w}$ & protein electrophoresis & genetic divergence & Wood \& Foote, 1996 \\
\hline ON & $\mathrm{w}$ & protein electrophoresis & genetic variation & Foote et al, 1989 \\
\hline ON & $\mathrm{W}$ & protein electrophoresis & genetic variation & Varnavskaya et al., 1994 \\
\hline ON & $\mathrm{w}$ & protein electrophoresis & genetic variation & Winans et al., 1996 \\
\hline ON & $\mathrm{w}$ & protein electrophoresis & population structure & Hendry et al., 1996 \\
\hline $\mathrm{ON}$ & $\mathrm{w}$ & protein electrophoresis & stock identification & Shaklee et al., 1996 \\
\hline
\end{tabular}




\begin{tabular}{|c|c|c|c|c|}
\hline Species & $\begin{array}{l}\text { type of } \\
\text { population }\end{array}$ & Marker type/method & Use & Reference \\
\hline $\mathrm{ON}$ & $\mathrm{w}$ & $\begin{array}{l}\text { scale patterns, protein } \\
\text { electrophoresis }\end{array}$ & stock identification & Wood et al., 1989 \\
\hline $\mathrm{ON}, \mathrm{OK}$ & $\mathrm{w}$ & protein electrophoresis & genetic variation & Akulin et al., 1975 \\
\hline $\begin{array}{l}\text { Oncorhynchus } \\
\text { spp. }\end{array}$ & $\mathrm{N} / \mathrm{A}$ & $\begin{array}{l}\text { mathematical/computer } \\
\text { modeling }\end{array}$ & modeling changes in allele frequency & Waples, 1990 \\
\hline $\begin{array}{l}\text { Oncorhynchus } \\
\text { spp. }\end{array}$ & $\mathrm{N} / \mathrm{A}$ & $\mathrm{N} / \mathrm{A}$ & $\begin{array}{l}\text { review; genetic variation in susceptibility to whirling } \\
\text { disesase }\end{array}$ & Allendorf, 2001 \\
\hline $\begin{array}{l}\text { Oncorhynchus } \\
\text { spp. }\end{array}$ & $\mathrm{W}$ & previously published data & genetic diversity & Waples et al, 2001 \\
\hline OT & $\mathrm{w} \& \mathrm{~h}$ & protein electrophoresis & population structure & Marshall et al., 2004 \\
\hline OT & $\mathrm{w}$ & microsatellite & stock structure & Banks et al., 1996 \\
\hline OT & $\mathrm{w} \& \mathrm{~h}$ & microsatellites & genetic comparison/diversity & Banks et al., 2000 \\
\hline OT & $\mathrm{h}$ & microsatellites & identification of microsatellites; inheritance of loci & Banks et al., 1999 \\
\hline OT & $\mathrm{W}$ & microsatellites & stock structure & Beacham et al., 2003a \\
\hline OT (Walbaum) & $\mathrm{W}$ & microsatellites & stock identification & Beacham et al, 2003b \\
\hline OT, OKi, ON & $\mathrm{U}$ & microsatellites & $\begin{array}{l}\text { identification, verification of Mendelian inheritance of } \\
\text { the markers }\end{array}$ & Nelson \& Beacham, 1999 \\
\hline OT & $\mathrm{w} \& \mathrm{~h}$ & minisatellites & stock identification & Beacham et al., 1996 \\
\hline OT & $\mathrm{W}$ & mtDNA & comparison of spawning runs & Nielsen et al. 1994 \\
\hline OT & $\mathrm{W}$ & mtDNA (RFLP) & population structure & Wilson et al., 1987 \\
\hline OT, OK & $\mathrm{W}$ & mtDNA (RFLP) & genetic variation & Cronin et al., 1993 \\
\hline OT & $\mathrm{W}$ & PCR of MHC gene & population structure & Kim et al., 1999 \\
\hline OT & $\mathrm{h}$ & protein electrophoresis & fertilization succes of individual males with pooled milt & Withler, 1988 \\
\hline SA & $\mathrm{w}$ & $\begin{array}{l}\text { chromosome evaluation, } \\
\text { mtDNA (RFLP \& sequencing), } \\
\text { protein electrophoresis }\end{array}$ & population structure & Hartley et al., 1992 \\
\hline SA & $\mathrm{h}$ & microsatellites & development of linkage map & Woram et al., 2003a \\
\hline SA & $\mathrm{w} \& \mathrm{~h}$ & microsatellites & genetic variation & Lundrigan et al., 2005 \\
\hline SA & $\mathrm{w}$ & microsatellites & population structure & Wilson et al., 2004 \\
\hline
\end{tabular}




\begin{tabular}{|c|c|c|c|c|}
\hline Species & $\begin{array}{l}\text { type of } \\
\text { population }\end{array}$ & Marker type/method & Use & Reference \\
\hline $\begin{array}{l}\text { SA, } 6 \text { additional } \\
\text { salmonid } \\
\text { species }\end{array}$ & $\mathrm{h}$ & microsatellites & amplification of SA microsatellites in other Salmonids & McGowan et al., 2004 \\
\hline $\mathrm{SA}, \mathrm{SF}$ & $\mathrm{w} \& \mathrm{~h}$ & mtDNA (RFLP) & introgression, $\mathrm{mt}$ genome of SA present in SF & Bernatchez et al., 1995 \\
\hline SA & $\mathrm{W}$ & protein electrophoresis & genetic variability & Anderson et al., 1983 \\
\hline SA & $\mathrm{W}$ & selective matings & evaluation of time of first feeding & Skulason et al., 1989 \\
\hline Salmosp. & $\mathrm{w}$ & $\begin{array}{l}\text { mtDNA (RFLP, sequence), } \\
\text { protein electrophoresis }\end{array}$ & genetic variation, phylogenic relationships & Bernatchez L, Osinov, 1995 \\
\hline Salvelinus spp & $\mathrm{W}$ & microsatellites & $\begin{array}{l}\text { use of microsatellites from brook char in other } \\
\text { Salvelinus spp }\end{array}$ & Angers \& Bernatchez, 1996 \\
\hline Salvelinus spp & $\mathrm{h}$ & protein electrophoresis & linkage and segregation of loci & May et al., 1979b \\
\hline $\begin{array}{l}\text { SC bouvieri, SC } \\
\text { lewisi }\end{array}$ & $\mathrm{W}$ & chromosome evaluation & taxonomy, genetic relationship between the subspecies & $\begin{array}{l}\text { Loudenslager \& Thorgaard, } \\
1979\end{array}$ \\
\hline SC lewisi & $\mathrm{w} \& \mathrm{~h}$ & meristic characters & developmental stablity \& heterozygosity & Leary et al., $1985 \mathrm{~b}$ \\
\hline $\mathrm{SC}$ & $\mathrm{w}$ & microsatellites & population structure & Spruell et al., 2003 \\
\hline $\mathrm{SC}, \mathrm{PW}$ & $\mathrm{W}$ & microsatellites & genetic variation, genetic divergence & Whiteley et al., 2004 \\
\hline $\begin{array}{l}\text { SC lewisi, SC } \\
\text { bouvieri }\end{array}$ & $\mathrm{w}$ & microsatellites, mtDNA & population structure & Kanda \& Allendorf, 2001 \\
\hline $\begin{array}{l}\text { SC lewisi, SC } \\
\text { bouvieri }\end{array}$ & $\mathrm{w}$ & $\begin{array}{l}\text { mtDNA, protein } \\
\text { electrophoresis }\end{array}$ & introgression between the subspecies & Gyllensten et al., 1985 \\
\hline $\mathrm{SC}, \mathrm{SF}$ & $\mathrm{W}$ & $\begin{array}{l}\text { PINE PCR, protein } \\
\text { electrophoresis }\end{array}$ & hybridization, introgression & Kanda et al., 2002b \\
\hline $\mathrm{SC}$ & $\mathrm{W}$ & protein electrophoresis & population structure & Leary et al., 1993 \\
\hline $\mathrm{SC}$ & $\mathrm{w}$ & protein electrophoresis & introgression and hybridization & Marnell et al., 1987 \\
\hline $\mathrm{SC}, \mathrm{SMa}$ & $\mathrm{W}$ & protein electrophoresis & identification of distinct, sympatric species & Leary \& Allendorf, 1997 \\
\hline SF & $\mathrm{W}$ & microsatellites & population structure & Angers et al., 1995 \\
\hline SF & $\mathrm{W}$ & mtDNA (RFLP) & genetic variation & Danzmann \& Ihssen, 1995 \\
\hline SF Mitchill & $\mathrm{w} \& \mathrm{~h}$ & mtDNA (RFLP) & genetic variation, phylogenic relationships & $\begin{array}{l}\text { Bernatchez \& Danzmann, } \\
1993\end{array}$ \\
\hline $\mathrm{SF}, \mathrm{SC}, \mathrm{Sma}$ & $\mathrm{W}$ & PINE-PCR & hybridization & Spruell et al., 2001 \\
\hline SF & $\mathrm{w} \& \mathrm{~h}$ & protein electrophoresis & genetic variation & Wright \& Atherton, 1968 \\
\hline
\end{tabular}




\begin{tabular}{|c|c|c|c|c|}
\hline Species & $\begin{array}{l}\text { type of } \\
\text { population }\end{array}$ & Marker type/method & Use & Reference \\
\hline SF & $\mathrm{h}$ & protein electrophoresis & linkage of duplicate loci & Wright et al., 1980 \\
\hline $\mathrm{SF}$ & $\mathrm{w}$ & protein electrophoresis & null alleles, loss of duplicate loci & Stoneking et al., 1981 \\
\hline SL & $\mathrm{h}$ & mtDNA (RFLP) & genetic variation & Danzmann et al., 1991 \\
\hline SL & N/A & protein electrophoresis & effects of hatchery fishes on wild population & Ryman et al., 1993 \\
\hline SN & $\mathrm{w} \& \mathrm{~h}$ & protein electrophoresis & genetic differentiation & Ihssen et al., 1988 \\
\hline SN & $\begin{array}{l}\mathrm{w}(\mathrm{h} \\
\text { stocks })\end{array}$ & $\begin{array}{l}\text { mtDNA, protein } \\
\text { electrophoresis }\end{array}$ & identification of successful stocked strains & Grewe et al., 1994 \\
\hline SN x SF hybrids & $\mathrm{h}$ & protein electrophoresis & linkage and segregation of loci & May et al., 1980 \\
\hline $\begin{array}{l}\text { SS, ST, and } \\
\text { hybrids }\end{array}$ & $\mathrm{w}$ & 5s rDNA & species identification & Pendas et al., 1995 \\
\hline SS & $\mathrm{w}$ & microsatellites & development of linkage map & Gilbey et al., 2003 \\
\hline SS & $\mathrm{w}$ & microsatellites & distribution of related individuals & Fontaine \& Dodson, 1999 \\
\hline SS & $\mathrm{w} \& \mathrm{~h}$ & microsatellites & genetic differentiation & McConnell et al, 1995a \\
\hline SS & $\mathrm{w} \& \mathrm{~h}$ & microsatellites & genetic diversity & Kloljonen et al., 2002 \\
\hline SS & $\mathrm{w} \& \mathrm{~h}$ & microsatellites & genetic diversity & Norris et al., 1999 \\
\hline SS & $\mathrm{w}$ & microsatellites & genetic variation & McConnell et al, 1995b \\
\hline SS & $\mathrm{w} \& \mathrm{~h}$ & microsatellites & genetic variation & O' Reilly et al., 1996 \\
\hline SS & $\mathrm{w}$ & microsatellites & genetic variation in extinct \& extant populations & Nielsen EE et al., 1999 \\
\hline SS & $\mathrm{w}$ & microsatellites & growth \& development & Gilbey et al., 2005 \\
\hline SS & $\mathrm{h}$ & microsatellites & parentage and relatedness & Norris et al., 2000 \\
\hline SS & $\mathrm{h}$ & microsatellites & parentage determination & O'Reilly et al., 1998 \\
\hline SS & $\mathrm{w} \& \mathrm{~h}$ & microsatellites & $\begin{array}{l}\text { performance comparison of native-wild, native-cultured } \\
\& \text { non-native stocks }\end{array}$ & McGinnity et al., 2004 \\
\hline SS & $\mathrm{w} \& \mathrm{~h}$ & microsatellites & $\begin{array}{l}\text { performance comparison of wild \& hatchery-reared } \\
\text { individuals }\end{array}$ & Skilbrei et al., 2004 \\
\hline SS, ST & $\mathrm{n} / \mathrm{a}$ & minisatellite & marker development, cross-species amplification & Prodohl et al., 1995 \\
\hline SS L. & $\mathrm{W}$ & microsatellites & genetic variation, population structure & Tessier et al., 1999 \\
\hline SS, SA & $\mathrm{h}$ & microsatellites & ability to predict genetic variability & Primmer et al., 2003 \\
\hline SS & $\mathrm{W}$ & microsatellites, 4 loci & population structure & Beacham \& Dempson 1998 \\
\hline SS & $\mathrm{w}$ & microsatellites, MCH gene & population structure & Landry \& Bernatchez \\
\hline
\end{tabular}




\begin{tabular}{|c|c|c|c|c|}
\hline Species & $\begin{array}{l}\text { type of } \\
\text { population }\end{array}$ & Marker type/method & Use & Reference \\
\hline SS L. & $\mathrm{w}$ & $\begin{array}{l}\text { microsatellites, mtDNA, } \\
\text { protein electrophoresis }\end{array}$ & genetic variation & Tessier et al., 1995 \\
\hline SS L. & $\mathrm{w}$ & $\begin{array}{l}\text { microsatellites, protein } \\
\text { electrophoresis }\end{array}$ & genetic varability, comparison of methods & Sanchez et al., 1996 \\
\hline SS & $\mathrm{w}$ & minisatellite & $\begin{array}{l}\text { marker development, evolutionary conservation of } \\
\text { marker }\end{array}$ & Bentzen \& Wright, 1993 \\
\hline SS L. & $\mathrm{h}$ & minisatellite & locus inheritance \& segregation & Taggart et al., 1995a \\
\hline SS L. & N/A & minisatellite & $\begin{array}{l}\text { marker development; suitability for genetic \& } \\
\text { population studies }\end{array}$ & Taggart \& Ferguson, 1990 \\
\hline SS L. & $\mathrm{h}$ & minisatellite, 1 locus & genetic stock identification & Galvin et al., 1995 \\
\hline SS & $\mathrm{w}$ & minisatellites & discrimination of European and North American strains & Taggart et al., $1995 \mathrm{~b}$ \\
\hline SS & $\mathrm{w} \& \mathrm{~h}$ & minisatellites & population structure & Galvin et al., 1996 \\
\hline SS L. & $\mathrm{w}$ & mtDNA & population structure & King et al., 2000 \\
\hline SS L. & $\mathrm{h}$ & mtDNA & identification of stocks & Palva et al., 1989 \\
\hline SS & $\mathrm{h}$ & mtDNA (RFLP) & identification of stock source & Bermingham et al., 1991 \\
\hline SS & $\mathrm{w}$ & protein electrophoresis & $\begin{array}{l}\text { association of geography, enivornmment, and } \\
\text { population genetic structure }\end{array}$ & Jordan et al., 2005 \\
\hline SS & $\mathrm{w} \& \mathrm{~h}$ & protein electrophoresis & contribution of wild \& stocked to fishery & Garcie de Leaniz et al., 1989 \\
\hline SS & $\mathrm{w} \& \mathrm{~h}$ & protein electrophoresis & $\begin{array}{l}\text { differences in genetic variation of wild \& hatchery } \\
\text { fishes }\end{array}$ & Stahl, 1983 \\
\hline SS & $\mathrm{w}$ & protein electrophoresis & effect of transplantation of wild parr & Moran et al., 1994b \\
\hline SS & $\mathrm{h}$ & protein electrophoresis & effects of hatchery fishes on wild population & Vazquez et al., 1993 \\
\hline SS & $\mathrm{w}$ & protein electrophoresis & genetic variation & Blanco et al., 2005 \\
\hline SS & $\mathrm{w}$ & protein electrophoresis & genetic variation & Cordes et al., 2005 \\
\hline SS & $\mathrm{w} \& \mathrm{~h}$ & protein electrophoresis & genetic variation & Crosier \& Moffett, 1989 \\
\hline SS & $\mathrm{w}$ & protein electrophoresis & genetic variation & Jordan et al., 1992 \\
\hline SS & $\mathrm{w}$ & protein electrophoresis & genetic variation & McElligot \& Cross, 1991 \\
\hline SS & $\mathrm{w}$ & protein electrophoresis & genetic variation & Moran et al., 1994a \\
\hline SS & $\mathrm{w}$ & protein electrophoresis & genetic variation & Moran et al., 2005 \\
\hline SS & $\mathrm{w}$ & protein electrophoresis & genetic variation & Skaala et al., 1998 \\
\hline SS & $\mathrm{w}$ & protein electrophoresis & genetic variation & Verspoor et al., 1989 \\
\hline
\end{tabular}




\begin{tabular}{|c|c|c|c|c|}
\hline Species & $\begin{array}{l}\text { type of } \\
\text { population }\end{array}$ & Marker type/method & Use & Reference \\
\hline SS & $\mathrm{w} \& \mathrm{~h}$ & protein electrophoresis & genetic variation of wild and hatchery fish & Youngson et al., 1991 \\
\hline SS & $\mathrm{w}$ & protein electrophoresis & genetic variation, population structure & Sanchez et al., 1991 \\
\hline SS & $\mathrm{w} \& \mathrm{~h}$ & protein electrophoresis & $\begin{array}{l}\text { loss of genetic variation due to selection of hatchery- } \\
\text { raised fishes }\end{array}$ & Cross \& King, 1983 \\
\hline SS & $\mathrm{h}$ & protein electrophoresis & loss of genetic variation in hatchery fishes & Verspoor, 1988 \\
\hline SS & $\mathrm{W}$ & protein electrophoresis & seasonal changes in stock composition & Koljonen \& McKinnell, 1996 \\
\hline SS & $\mathrm{W}$ & protein electrophoresis & selection \& gene flow & Verspoor et al., 1991 \\
\hline SS L. & $\mathrm{W}$ & protein electrophoresis & genetic differentiation & Blanco et al., 1992 \\
\hline SS L. & $\mathrm{W}$ & protein electrophoresis & genetic variation & Cross \& Ward, 1980 \\
\hline$\overline{\text { SS L. }}$ & $\mathrm{W}$ & protein electrophoresis & genetic variation & Hurrel \& Price 1993 \\
\hline SS L. & w \& h & protein electrophoresis & genetic variation & Verspoor \& McCarthy, 1997 \\
\hline SS L. & $\mathrm{w} \& \mathrm{~h}$ & protein electrophoresis & genetic variation & Verspoor, 2005 \\
\hline SS L. & $\mathrm{w}$ & protein electrophoresis & natural selection, population structure & Jordan et al., 1997 \\
\hline SS L. & $\mathrm{W}$ & protein electrophoresis & reproductive success of males & Jordan \& Youngson, 1992 \\
\hline SS sebago & $\mathrm{w}$ & protein electrophoresis & genetic variation & Vuorinen, 1982 \\
\hline$\overline{S S}$ & w \& h & protein electrophoresis & genetic variation & Bourke et al., 1997 \\
\hline SS & $\mathrm{w} \& \mathrm{~h}$ & protein electrophoresis & genetic structure & Danielsdottir et al., 1997 \\
\hline SS & $\mathrm{h} \& \mathrm{w}$ & RFLP of mtDNA, minisatellite & identification of wild \& hatchery & Clifford et al., 1998 \\
\hline SS & $\mathrm{h}$ & selective matings & disease resistance, genetic change due to selection & Gjedrem \& Aulstad, 1974 \\
\hline SS & $\mathrm{h}$ & selective matings & resistance to louse & Kolstad, 2005 \\
\hline SS & $\mathrm{h}$ & selective matings & $\begin{array}{l}\text { return of released smolts, comparison of weight gain in } \\
\text { sea-verus land-ranched }\end{array}$ & Jonassen et al., 1997 \\
\hline SS & $\mathrm{h}$ & selective matings & diesease resistance & Gjedrem et al., 1991 \\
\hline SS L. & $\mathrm{h}$ & selective matings & genetic variation in immune response & Lund et al., 1995 \\
\hline $\mathrm{ST}$ & $\mathrm{N} / \mathrm{A}$ & computer simulation & $\begin{array}{l}\text { mathematic model to evaluate the effects of selective } \\
\text { fishing on population genetics }\end{array}$ & Favro et al., 1979 \\
\hline $\mathrm{ST}$ & $\mathrm{w}$ & $\begin{array}{l}\text { DNA fingerprinting via } \\
\text { minisatellite probes }\end{array}$ & genetic variability & Prodohl et al., 1992 \\
\hline $\mathrm{ST}$ & $\mathrm{h}$ & LDH-gene & $\begin{array}{l}\text { marker development, potential use of marker in } \\
\text { population genetic studies }\end{array}$ & McMeel et al., 2001 \\
\hline ST & $\mathrm{w}$ & microsatellites & effects of supplemental stocking & Hansen, 2002 \\
\hline
\end{tabular}




\begin{tabular}{|c|c|c|c|c|}
\hline Species & $\begin{array}{l}\text { type of } \\
\text { population }\end{array}$ & Marker type/method & Use & Reference \\
\hline ST & $\mathrm{w} \& \mathrm{~h}$ & microsatellites & fate of stocked invididuals, stocking impact, migration & Ruzzante et al., 2004 \\
\hline ST & $\mathrm{w} \& \mathrm{~h}$ & microsatellites & species identification; impact of introduced O. mykiss & Fritzner et al., 2001 \\
\hline ST & $\mathrm{w} \& \mathrm{~h}$ & $\begin{array}{l}\text { microsatellites \& protein } \\
\text { electrophoresis }\end{array}$ & comparison of analyses (microsatellite vs. allozyme) & Estoup et al., 1998b \\
\hline ST & $\mathrm{w}$ & $\begin{array}{l}\text { microsatellites, protein } \\
\text { electrophoresis }\end{array}$ & population structure & Corujo et al., 2004 \\
\hline ST & $\mathrm{W}$ & mtDNA & genetic differentiation & Hansen \& Loeschcke, 1996 \\
\hline ST & $\mathrm{W}$ & mtDNA & genetic differentiation & Hansen et al., 1998 \\
\hline ST & $\mathrm{W}$ & mtDNA (sequence) & genetic variation, phylogenic relationships & Bernatchez et al., 1992 \\
\hline ST & $\mathrm{w} \& \mathrm{~h}$ & protein electrophoresis & $\begin{array}{l}\text { comparison of wild \& nonwild; comparison of } \\
\text { pigmentation pattern to allozyme identification of } \\
\text { stocks }\end{array}$ & Aparicio et al, 2005 \\
\hline ST & $\mathrm{W}$ & protein electrophoresis & examination of dupliate loci \& null alleles & Allendorf, Stahl, Ryman \\
\hline ST & $\mathrm{W}$ & protein electrophoresis & genetic diversity, population structure & Faundez et al., 1997 \\
\hline ST & $\mathrm{w} \& \mathrm{~h}$ & protein electrophoresis & genetic variability, genetic divergence & Martinez et al., 1993 \\
\hline ST & $\mathrm{w} \& \mathrm{~h}$ & protein electrophoresis & genetic variation & Garcia-Marin et al., 1991 \\
\hline ST & $\mathrm{w} \& \mathrm{~h}$ & protein electrophoresis & genetic variation & Kreig \& Guyomard, 1985 \\
\hline ST & $\mathrm{W}$ & protein electrophoresis & genetic variation, population structure & Chakraborty et al., 1982 \\
\hline ST & $\mathrm{W}$ & protein electrophoresis & identification of reproductively isolated populations & Ferguson \& Mason, 1981. \\
\hline ST & $\mathrm{w} \& \mathrm{~h}$ & protein electrophoresis & impact of hatchery fish on wild stocks & Skaala et al., 1996 \\
\hline ST & $\mathrm{W}$ & protein electrophoresis & population structure & Crozier \& Ferguson, 1986 \\
\hline ST & $\mathrm{W}$ & protein electrophoresis & population structure & Sanz et al., 2002 \\
\hline ST & $\mathrm{w} \& \mathrm{~h}$ & protein electrophoresis & population structure, genetic change in hatchery stocks & Ryman \& Stahl, 1980 \\
\hline ST & $\mathrm{W}$ & protein electrophoresis & reproductive isolation & Ryman et al, 1979 \\
\hline ST & $\mathrm{W}$ & protein electrophoresis & stock identification & Krueger \& May, 1987a \\
\hline ST & $\mathrm{W}$ & protein electrophoresis & viability of stocked fish & Arias et al., 1995 \\
\hline ST & $\mathrm{h}$ & protein electrophoresis & inheritance \& segragation of loci & May et al., 1979a \\
\hline ST L & $\mathrm{N} / \mathrm{A}$ & microsatellites & $\begin{array}{l}\text { marker development, inheritance of loci, marker use in } \\
\text { other salmonids }\end{array}$ & Estoup, 1993 \\
\hline ST L & $\mathrm{W}$ & PCR-RFLP & genetic differentiation; phylogeny & Apostolidis, 1996 \\
\hline ST L & $\mathrm{W}$ & protein electrophoresis & genetic variation, geographical distribution & Garcia-Marin et al., 1999 \\
\hline
\end{tabular}




\begin{tabular}{|c|c|c|c|c|}
\hline Species & $\begin{array}{l}\text { type of } \\
\text { population }\end{array}$ & Marker type/method & Use & Reference \\
\hline ST L. & $\mathrm{w}$ & $\begin{array}{l}\text { microsatellites, protein } \\
\text { electrophoresis }\end{array}$ & examination of genetic diversity & Colihueque et al., 2003 \\
\hline ST L. & $\mathrm{h}$ & minisatellite & locus inheritance, joint segregation analysis & Prodohl et al., 1994 \\
\hline ST L. & $\mathrm{W}$ & mtDNA & genetic variation & Bernatchez et al., 2001 \\
\hline ST L. & $\mathrm{w}$ & mtDNA & phylogeography & Apostolidis, 1997 \\
\hline ST L. & $\mathrm{w}$ & mtDNA (RFLP) & phylogeny, population structure & Hynes et al., 1996 \\
\hline ST L. & $\mathrm{w}$ & mtDNA, minisatellites & genetic variation & Prodohl et al., 1997 \\
\hline ST L. & $\mathrm{w} \& \mathrm{~h}$ & protein electrophoresis & failure of stocking enhancement of wild population & Moran et al., 1991 \\
\hline ST L. & $\mathrm{w}$ & protein electrophoresis & gene flow between populations & Moran et al, 1995 \\
\hline ST L. & $\mathrm{w} \& \mathrm{~h}$ & protein electrophoresis & genetic variability & Guyomard \& Kreig, 1983 \\
\hline ST L. & $\mathrm{w}$ & protein electrophoresis & genetic variation & Allendorf et al ., 1976 \\
\hline ST L. & $\mathrm{W}$ & protein electrophoresis & genetic variation & Allendorf et al., 1977 \\
\hline ST L. & $\mathrm{w}$ & protein electrophoresis & genetic variation & Berrebi et al., 2000 \\
\hline ST L. & $\mathrm{W}$ & protein electrophoresis & hybridization, introgression & Largiader \& Scholl, 1996 \\
\hline ST L. & $\mathrm{W}$ & protein electrophoresis & identification of ancestral populations & Hamilton et al., 1989 \\
\hline ST L., ST F. & $\mathrm{h}$ & selective matings & $\begin{array}{l}\text { influence of heredity \& environment on fin coloration } \\
\& \text { body length at sexual maturity }\end{array}$ & Alm, 1949 \\
\hline $\begin{array}{l}\text { ST X SS } \\
\text { hybrids }\end{array}$ & $\mathrm{w}$ & protein electrophoresis & identification of naturally occuring hybrids & Crosier, 1984 \\
\hline ST, OM, SS & $\mathrm{h}$ & microsatellites & use of markers for interspecific comparison & Presa et al., 1996 \\
\hline ST, SM & $\mathrm{w} \& \mathrm{~h}$ & microsatellites & introgression of native and non-native & Jug et al., 2005 \\
\hline unspecified & N/A & computer simulation & $\begin{array}{l}\text { mathematic model to evaluate the effects of selective } \\
\text { fishing on growth rate }\end{array}$ & Favro et al., 1979 \\
\hline $\begin{array}{l}\text { various } \\
\text { Oncorhynchus }\end{array}$ & $\mathrm{w} \& \mathrm{~h}$ & mtDNA (RFLP) & salmonid evolution, phylogeny & Thomas et al., 1986 \\
\hline various & $\mathrm{w} \& \mathrm{~h}$ & N/A (review) & effects of Salmonid introductions & Krueger \& May, 1991 \\
\hline various & $\mathrm{u}$ & mtDNA gene sequencing & phylogenic relationships & McVeigh \& Davidson, 1991 \\
\hline various & N/A & $\begin{array}{l}\text { mtDNA and nuclear DNA } \\
\text { sequence }\end{array}$ & phylogeny & Crespi \& Fulton, 2004 \\
\hline various & N/A & N/A (review) & $\begin{array}{l}\text { review of methods in molecular biology as it applies to } \\
\text { identification }\end{array}$ & Ferguson et al., 1995 \\
\hline
\end{tabular}




\begin{tabular}{|l|l|l|l|l|} 
Species & $\begin{array}{l}\text { type of } \\
\text { population }\end{array}$ & Marker type/method & Use & Reference \\
\hline various & w \& h & protein electrophoresis & isozymes of malate dehydrogenase in Salmonids & Bailey et al., 1970 \\
\hline various & N/A & RFLP of ribosomal DNA & phylogeny & Phillips et al., 1992 \\
\hline various & w & protein electrophoresis & review; evaluation of stock structure & Altukhov, 1981 \\
\hline various & N/A & N/A (review) & review of heritabilities, effects of selection & Gjedrem, 1976 \\
\hline various & w \& h & microsatellites & $\begin{array}{l}\text { examination of one microsatellite locus among } \\
\text { Salmonids }\end{array}$ & Angers \& Bernatchez, 1997 \\
\hline various & N/A & SINE & phylogenic relationships of Salmonidae & Murata et al., 1993 \\
\hline
\end{tabular}

$\mathrm{w}=$ wild, $\mathrm{h}=$ hatchery, $\mathrm{u}=$ unspecified

$\mathrm{OC}=\mathrm{O}$. clarki; $\mathrm{OG}=\mathrm{O}$. gorbuscha; $\mathrm{OI}=\mathrm{O}$. ishikawai; $\mathrm{OM}=\mathrm{O}$. mykiss, $(\mathrm{s})=$ steelhead, $\mathrm{r}=$ rainbow; $\mathrm{ON}=\mathrm{O}$. nerka; $\mathrm{OK}=\mathrm{O}$. keta

Oki $=$ O. kisutch; $O R=O$. rhoduras; $O T=O$. tshawytscha; $P W=P$. williamsoni; $S A=S$. alpinus; $S C=S$. confluentus; $S F=S$. fontinalis

Sma $=$ S. malma; $S M=$ S. marmoratus; $S N=$ S. namaycush; $S S=$ S. salar $; S T=S$. trutta

AFLP, Amplified fragment length polymorphism; BAC, bacterial artificial chromosome; mtDNA, mitochondrial DNA; PINE, paired interspersed

nuclear element; RAPD, randomly amplified polymorphic DNA; RFLP, restriction fragment length polymorphism; scnDNA, single copy nuclear DNA;

SINE, short interspersed nuclear element; SSCP, single strand conformational polymorphism; VNTR, variable number tandem repeat; QTL, quantitative

trait loci; EST, expressed sequence tag 
Table 4. Strains of Rainbow Trout used in Microsatellite Analysis

\begin{tabular}{|c|c|c|c|c|}
\hline $\begin{array}{l}\text { ID } \\
\text { No. }\end{array}$ & Strain ID & Broodstock & Hatchery & $\begin{array}{l}\text { Location of } \\
\text { Stock/Collection }\end{array}$ \\
\hline 4 & Arlee (ARL) & ARD/Arlee-D & Erwin NFH & Erwin, TN \\
\hline 21 & Big Spring (BS) & Big Spring (PA) 1 & Huntsdale FCS & Carlisle, PA \\
\hline 156 & Colorado River (CR) & CR-GS & Glenwood Springs Hatchery & Glenwood Springs, CO \\
\hline 44 & Eagle Lake (EL) & Eagle Lake (ERW) & Erwin NFH & Erwin, TN \\
\hline 53 & Ennis $(\mathrm{EN})$ & Paint Bank & Paint Bank FCS & Paint Bank, VA \\
\hline 56 & Erwin (ERW) & Erwin (ENN) & Ennis NFH & Ennis, MT \\
\hline 85 & Kamloops (KLS) & Lake Superior & French River Coldwater SFH & Duluth, MN \\
\hline 92 & Kamloops (KTL) & Trout Lodge (MD) & Albert Powell SFH & Hagerstown, MD \\
\hline 127 & Shasta (SHA) & Shasta (IA) & Manchester SFH & Manchester, IA \\
\hline 148 & Wytheville (WYT) & Petersburg & Petersburg SFH & Petersburg, WV \\
\hline
\end{tabular}


Table 5. Microsatellites Identified in Rainbow Trout TAGA and ATG Repeat-Enriched Libraries

\begin{tabular}{|c|c|c|c|c|c|c|c|c|}
\hline Marker ID & Repeat & $\begin{array}{c}\text { Forward Primer } \\
\text { Sequence }\end{array}$ & $\begin{array}{c}\text { Reverse Primer } \\
\text { Sequence }\end{array}$ & $\begin{array}{l}\text { Annealing } \\
\text { Temp, }{ }^{\circ} \mathrm{C} \\
\end{array}$ & $\begin{array}{c}\text { Product } \\
\text { Length, } \\
\text { bp } \\
\end{array}$ & $\begin{array}{c}\text { Successful } \\
\text { PCR } \\
\end{array}$ & $\begin{array}{c}\begin{array}{c}\text { Poly- } \\
\text { morphic }\end{array} \\
\end{array}$ & GenBank ID \\
\hline OMM1443 & (GT)17 & $\begin{array}{c}\text { ACC CGT AGT GTA } \\
\text { TTA GCT GGC }\end{array}$ & $\begin{array}{c}\text { TCT TGT GTG TCC } \\
\text { CCT ATC TGT }\end{array}$ & 55 & 311 & $\mathrm{Y}$ & $\mathrm{Y}$ & BV079588 \\
\hline OMM1445 & (GT) 15 & $\begin{array}{c}\text { CTG CGT TAT TGG } \\
\text { TAG CTT GTG } \\
\end{array}$ & $\begin{array}{c}\text { CCC GGT AAT GTA } \\
\text { GTT CCT GTC }\end{array}$ & $60-64$ & 181 & $\mathrm{Y}$ & $\mathrm{Y}$ & BV079589 \\
\hline OMM1447 & (GT)15 & $\begin{array}{c}\text { AGC TTA TCT TTT } \\
\text { CCT CCA CTG }\end{array}$ & $\begin{array}{c}\text { TTT GTG ACC TTA } \\
\text { ATT GCC TAC }\end{array}$ & 55 & 195 & $\mathrm{Y}$ & $\mathrm{Y}$ & BV079591 \\
\hline OMM1448 & $\begin{array}{c}\text { (GATA)IMPER- } \\
\text { FECT \& (GA) } 8\end{array}$ & $\begin{array}{c}\text { TCT GGG ATG GCA } \\
\text { CTA TCT TC }\end{array}$ & $\begin{array}{c}\text { TCC CTG TAG ACT } \\
\text { TCA AAC ACG } \\
\end{array}$ & 55 & 284 & $\mathrm{Y}^{*}$ & $\mathrm{Y}$ & BV079592 \\
\hline$\underset{D}{D M M 1449}$ & (CTAT) 15 & $\begin{array}{c}\text { CTT GCA GAG CCA } \\
\text { CAC TAA AC }\end{array}$ & $\begin{array}{c}\text { ACG ACA CTG TCT } \\
\text { GGG TAA GAG }\end{array}$ & 60 & 159 & $\mathrm{Y}$ & $\mathrm{Y}$ & BV079593 \\
\hline OMM1452 & (CAT)6 & $\begin{array}{c}\text { GCA GCA AAA GGT } \\
\text { GGC ACT ACA }\end{array}$ & $\begin{array}{c}\text { CCG AAC ATT ACA } \\
\text { CCA TCC TTG C }\end{array}$ & 65 & 365 & $\mathrm{Y}$ & $\mathrm{Y}$ & BV079596 \\
\hline OMM1453 & $\begin{array}{l}\text { (AC)8--(AC)12-- } \\
\text { (GAAA)3(CA)8 }\end{array}$ & $\begin{array}{c}\text { TTG GGA TGC GGA } \\
\text { CAG TTT G }\end{array}$ & $\begin{array}{c}\text { ACG AGG GAA ATA } \\
\text { AAA ATG CAG TC }\end{array}$ & $66-7$ & 324 & $\mathrm{Y}$ & $\mathrm{Y}$ & BV079597 \\
\hline OMM1454 & $(\mathrm{CCAT}) 11$ & $\begin{array}{c}\text { GTC CAG TTG ATG } \\
\text { AGC ATT GTG }\end{array}$ & $\begin{array}{c}\text { GCT TAC TGA TCC } \\
\text { ACC ATG TTG }\end{array}$ & 64 & 248 & $\mathrm{Y}$ & $\mathrm{Y}$ & BV079598 \\
\hline OMM1455 & (CATC) 7 & $\begin{array}{c}\text { CAT CTC TCG CTG } \\
\text { TCC CTC TA }\end{array}$ & $\begin{array}{c}\text { GGG AAG GGT AGG } \\
\text { GAA TGG }\end{array}$ & 64 & 206 & $\mathrm{Y}$ & $\mathrm{Y}$ & BV079599 \\
\hline OMM1456 & (AG) 21 & $\begin{array}{c}\text { CCA CGC AAG CCA } \\
\text { GCA AAA C }\end{array}$ & $\begin{array}{c}\text { TCC GCT GCT CTC } \\
\text { CTC TGA CTG }\end{array}$ & 68 & 334 & $\mathrm{Y}$ & $\mathrm{Y}$ & BV079600 \\
\hline
\end{tabular}




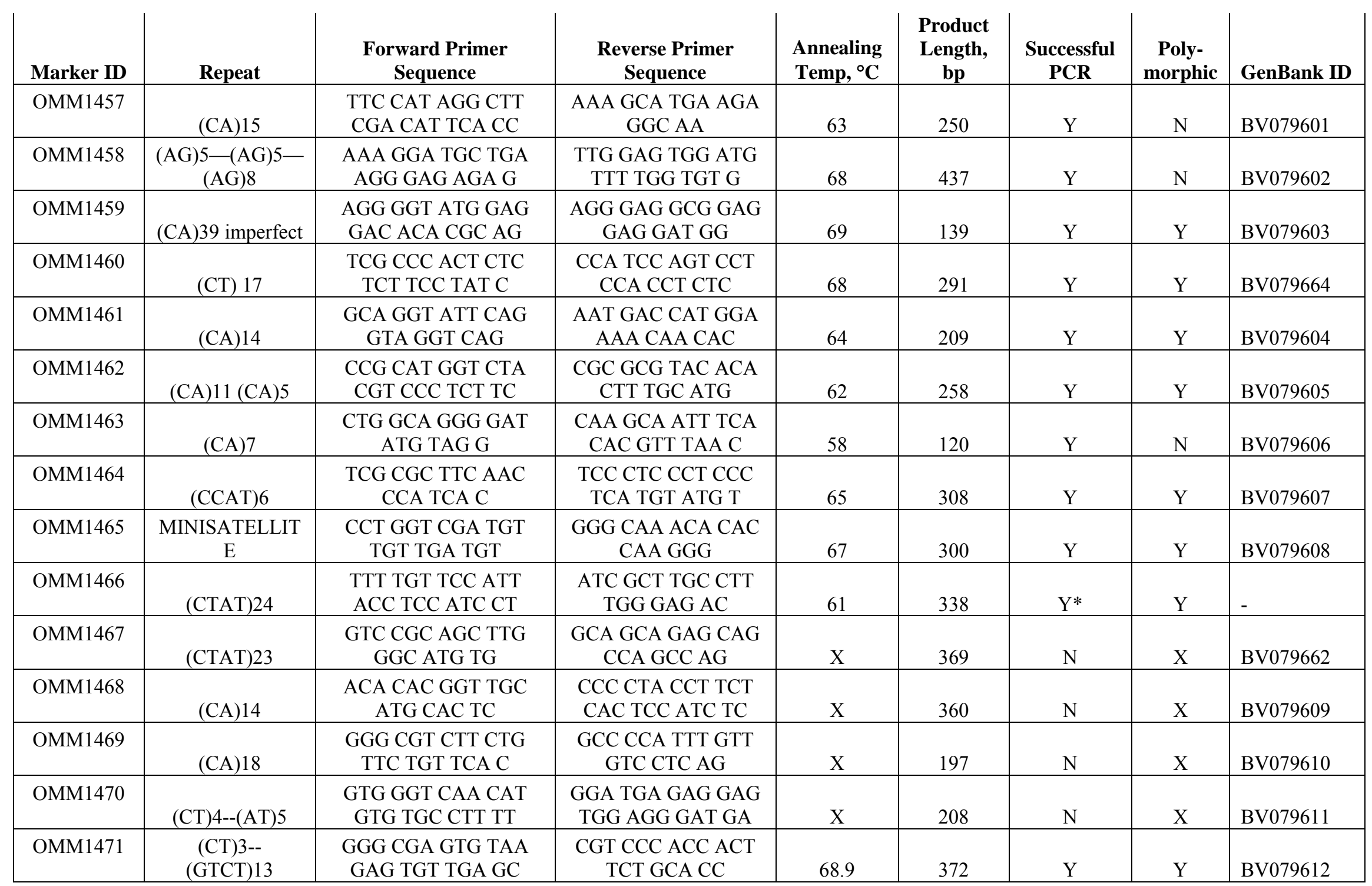




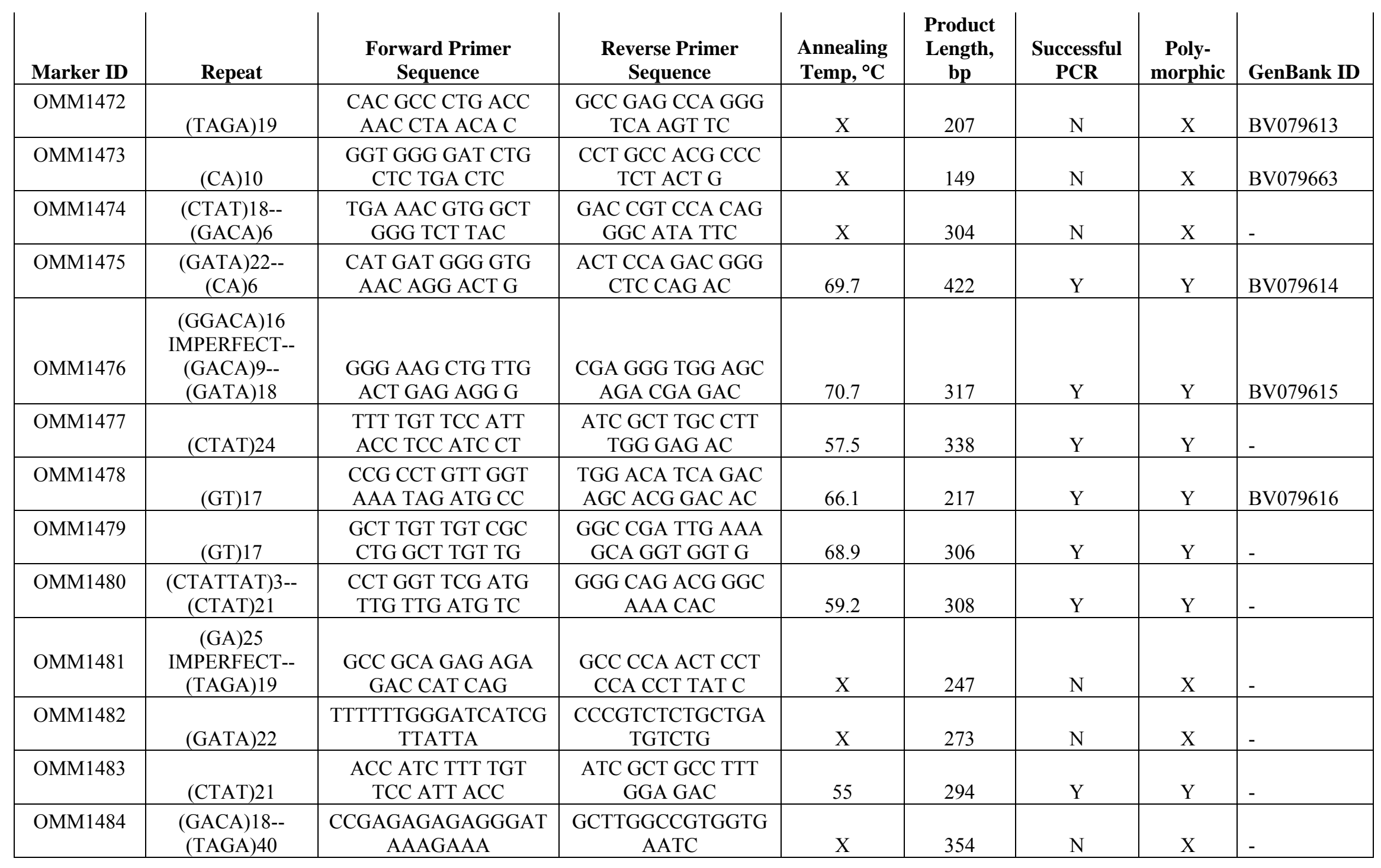




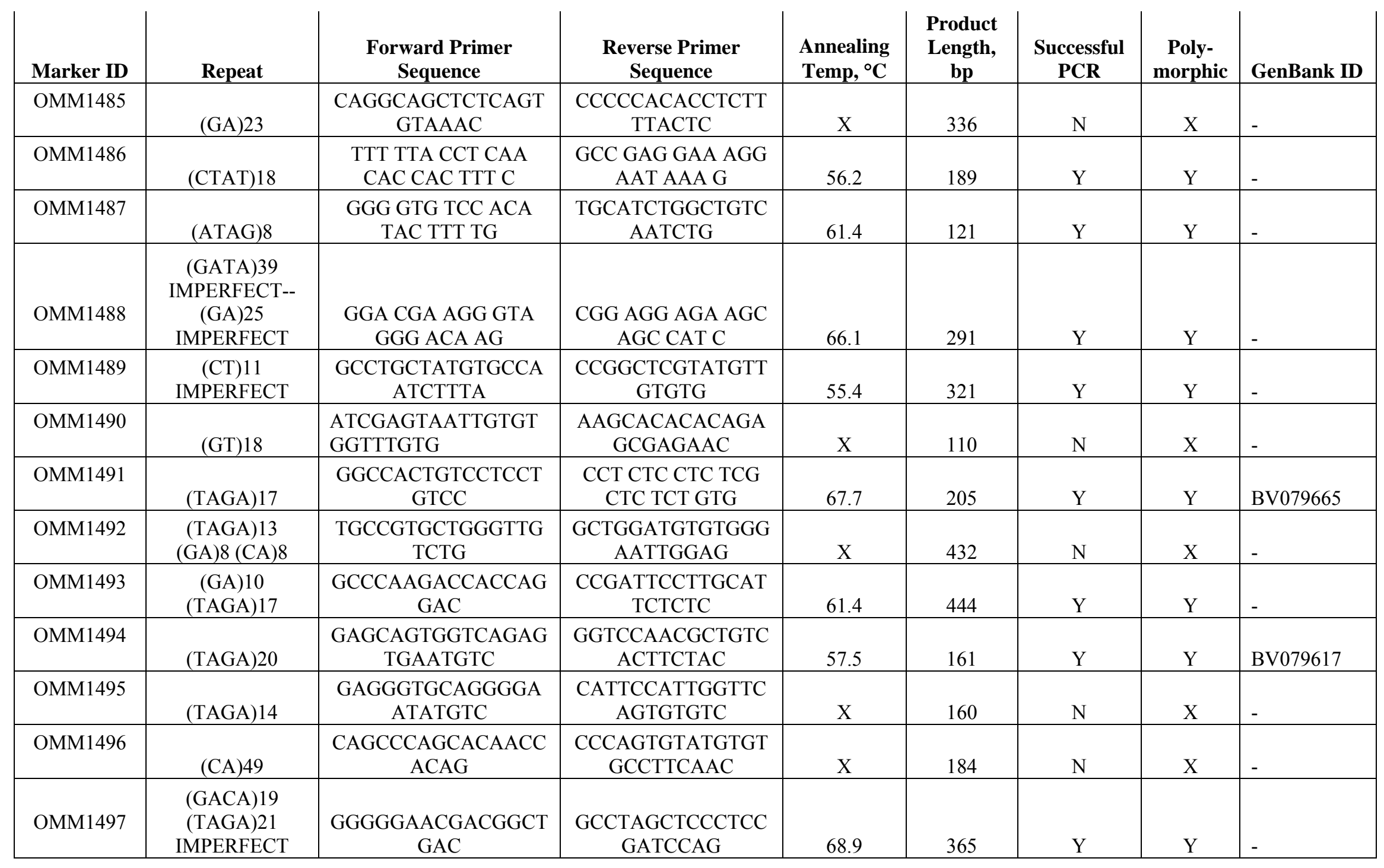




\begin{tabular}{|c|c|c|c|c|c|c|c|c|}
\hline Marker ID & Repeat & $\begin{array}{c}\text { Forward Primer } \\
\text { Sequence }\end{array}$ & $\begin{array}{c}\text { Reverse Primer } \\
\text { Sequence }\end{array}$ & $\begin{array}{l}\text { Annealing } \\
\text { Temp, }{ }^{\circ} \mathrm{C}\end{array}$ & $\begin{array}{c}\text { Product } \\
\text { Length, } \\
\text { bp }\end{array}$ & $\begin{array}{l}\text { Successful } \\
\text { PCR }\end{array}$ & $\begin{array}{c}\text { Poly- } \\
\text { morphic }\end{array}$ & GenBank ID \\
\hline OMM1498 & $\begin{array}{l}\text { (TAGA)20 } \\
\text { IMPERFECT }\end{array}$ & $\begin{array}{c}\text { CAATTGGAAGGTCAT } \\
\text { GGTAACTC }\end{array}$ & $\begin{array}{c}\text { CTCCCACCGTCCTT } \\
\text { GTCTCTC }\end{array}$ & $\mathrm{X}$ & 306 & $\mathrm{~N}$ & $X$ & \\
\hline
\end{tabular}

*amplification required 45 cycles and additional template DNA 
Table 6. The Variety of Alleles Found at Each Microsatellite Locus in 10 Strains of Rainbow Trout

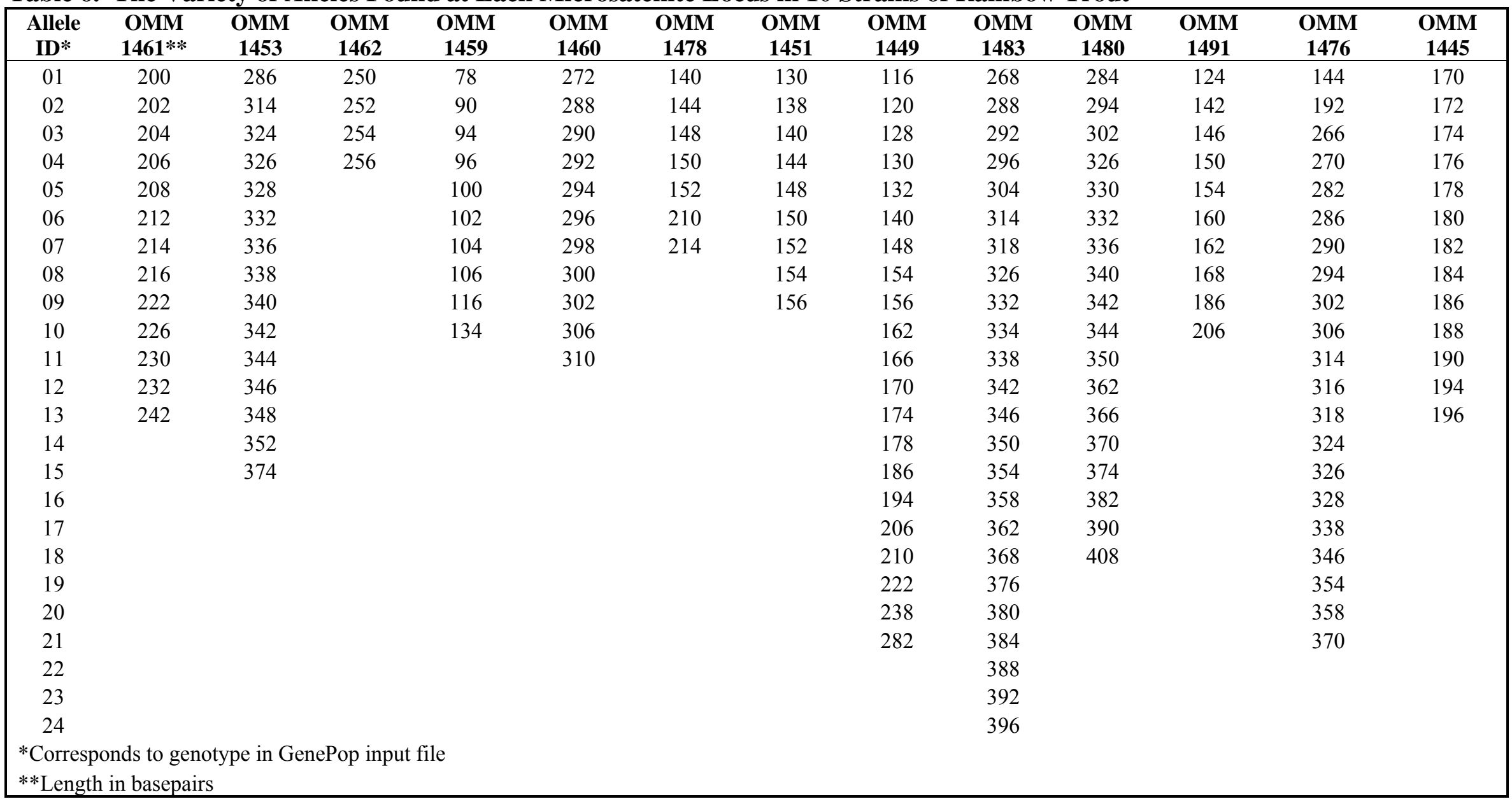


Table 7. Strains of Rainbow Trout with Unique Alleles at Each Locus

\begin{tabular}{|c|c|c|c|c|c|c|c|c|c|c|c|c|c|c|}
\hline Strain & $\begin{array}{c}\text { Locus } \\
\text { OMM } \\
1461 \\
\end{array}$ & $\begin{array}{c}\text { OMM } \\
1453 \\
\end{array}$ & $\begin{array}{c}\text { OMM } \\
1462 \\
\end{array}$ & $\begin{array}{c}\text { OMM } \\
1459 \\
\end{array}$ & $\begin{array}{c}\text { OMM } \\
1460 \\
\end{array}$ & $\begin{array}{c}\text { OMM } \\
1478 \\
\end{array}$ & $\begin{array}{c}\text { OMM } \\
1451 \\
\end{array}$ & $\begin{array}{c}\text { OMM } \\
1449 \\
\end{array}$ & $\begin{array}{c}\text { OMM } \\
1483 \\
\end{array}$ & $\begin{array}{c}\text { OMM } \\
1480 \\
\end{array}$ & $\begin{array}{c}\text { OMM } \\
1491 \\
\end{array}$ & $\begin{array}{c}\text { OMM } \\
1476 \\
\end{array}$ & $\begin{array}{c}\text { OMM } \\
1445 \\
\end{array}$ & Tota \\
\hline ARL & 206 & & & & & & 130 & & 338 & & & 324 & & 3 \\
\hline BS & $\begin{array}{l}200, \\
230\end{array}$ & 344 & & & & & & 130 & & 362 & & $\begin{array}{l}144, \\
290, \\
326\end{array}$ & & 8 \\
\hline CR & - & $\begin{array}{l}314, \\
332\end{array}$ & & & & & 156 & 156 & $\begin{array}{l}350, \\
368\end{array}$ & & $\begin{array}{l}142, \\
162 \\
\end{array}$ & $\begin{array}{l}192, \\
370\end{array}$ & & 10 \\
\hline EL & 242 & $\begin{array}{l}286, \\
374 \\
\end{array}$ & & & 306 & 140 & & & 288 & & & $\begin{array}{c}266, \\
294 \\
\end{array}$ & & 8 \\
\hline EN & 222 & 0 & 0 & & & & & & $\begin{array}{c}296, \\
314\end{array}$ & 390 & & 316 & & 5 \\
\hline ERW & & & & & & & & & 392 & & & & & 1 \\
\hline KLS & 216 & $\begin{array}{l}328, \\
342, \\
352 \\
\end{array}$ & 0 & & & 0 & $\begin{array}{l}138, \\
154 \\
\end{array}$ & $\begin{array}{l}116, \\
120, \\
132 \\
\end{array}$ & 396 & 344 & 124 & & & 12 \\
\hline KTL & & 338 & & & & & & & & & & & & 1 \\
\hline SHA & & & & & & & & & $\begin{array}{c}292, \\
332 \\
\end{array}$ & $\begin{array}{l}382, \\
408 \\
\end{array}$ & & 258 & 194 & 6 \\
\hline WYT & 0 & & & $\begin{array}{c}90, \\
94,96 \\
\end{array}$ & - & $\begin{array}{l}210, \\
214 \\
\end{array}$ & 0 & & & 294 & & & & 7 \\
\hline $\begin{array}{c}\text { Total } \\
\text { Unique }\end{array}$ & 6 & 9 & 0 & 3 & 1 & 3 & 4 & 5 & 334 & 6 & 3 & 10 & 1 & 385 \\
\hline $\begin{array}{l}0 \text { (did no } \\
\text { unavaila }\end{array}$ & $\begin{array}{l}\text { amplify) } \\
\text { le) }\end{array}$ & & ata & & & & & & & & & & & \\
\hline
\end{tabular}


Table 8. Number of Alleles in Each Rainbow Trout Strain and Average Heterozygosity (H) Within and Among Strains

\begin{tabular}{|c|c|c|c|c|c|c|c|c|c|c|c|}
\hline Locus & $\begin{array}{c}\text { Avg. } \\
\text { H }\end{array}$ & $\begin{array}{l}\text { ARL } \\
\text { No. } \\
\text { alleles }\end{array}$ & $\mathrm{H}$ & $\begin{array}{c}\text { BS } \\
\text { No. } \\
\text { alleles }\end{array}$ & $\mathrm{H}$ & $\begin{array}{c}\mathrm{CR} \\
\text { No. } \\
\text { alleles }\end{array}$ & $\mathrm{H}$ & $\begin{array}{c}\text { EL } \\
\text { No. } \\
\text { alleles }\end{array}$ & $\mathrm{H}$ & $\begin{array}{c}\text { EN } \\
\text { No. } \\
\text { alleles }\end{array}$ & $\mathrm{H}$ \\
\hline OMM1461 & 0.564 & 4 & 0.500 & 7 & 0.700 & - & - & 4 & 0.600 & 5 & 0.600 \\
\hline OMM1453 & 0.561 & 5 & 0.800 & 4 & 0.600 & 3 & 0.125 & 4 & 0.667 & 0 & 0.000 \\
\hline OMM1462 & 0.370 & 1 & 0.000 & 3 & 0.400 & 4 & 0.500 & 2 & 0.400 & 2 & 0.500 \\
\hline OMM1459 & 0.620 & 4 & 1.000 & 4 & 0.800 & 6 & 0.700 & 3 & 0.400 & 0 & 0.000 \\
\hline OMM1460 & 0.278 & 4 & 0.500 & 5 & 0.571 & 8 & 0.600 & 5 & 0.300 & 3 & 0.100 \\
\hline OMM1478 & 0.000 & 3 & 0.000 & 2 & 0.000 & 3 & 0.000 & 5 & 0.000 & 2 & 0.000 \\
\hline OMM1451 & 0.430 & 4 & 0.500 & 2 & 0.800 & 4 & 0.700 & 5 & 0.500 & 2 & 0.100 \\
\hline OMM1449 & 0.563 & 3 & 0.667 & 6 & 0.700 & 7 & 0.600 & 6 & 0.400 & 4 & 0.667 \\
\hline OMM1483 & 0.768 & 6 & 0.889 & 5 & 0.778 & 8 & 0.700 & 10 & 0.900 & 7 & 0.800 \\
\hline OMM1480 & 0.735 & 3 & 0.333 & 6 & 0.500 & - & - & 7 & 0.889 & 6 & 0.900 \\
\hline OMM1491 & 0.561 & 5 & 0.800 & 5 & 1.000 & 7 & 0.889 & 5 & 0.600 & 3 & 0.100 \\
\hline OMM1476 & 0.451 & 7 & 0.600 & 7 & 0.900 & 3 & 0.200 & 6 & 0.600 & 3 & 0.000 \\
\hline OMM1445 & 0.620 & 8 & 0.900 & 8 & 0.900 & 5 & 1.000 & 8 & 0.700 & 8 & 0.600 \\
\hline $\begin{array}{c}\text { MEAN } \\
\pm \text { SE }\end{array}$ & 0.502 & 4.4 & $\begin{array}{c}0.576 \pm \\
0.089\end{array}$ & 4.9 & $\begin{array}{c}0.665 \pm \\
0.073\end{array}$ & 5.3 & $\begin{array}{c}0.547 \pm \\
0.095\end{array}$ & 5.4 & $\begin{array}{c}0.535 \pm \\
0.068\end{array}$ & 4.1 & $\begin{array}{c}0.397 \pm \\
0.103\end{array}$ \\
\hline
\end{tabular}




\begin{tabular}{|c|c|c|c|c|c|c|c|c|c|c|}
\hline Locus & $\begin{array}{l}\text { ERW } \\
\text { No. } \\
\text { alleles }\end{array}$ & $\mathrm{H}$ & $\begin{array}{c}\text { KLS } \\
\text { No. } \\
\text { alleles }\end{array}$ & $\mathrm{H}$ & $\begin{array}{c}\text { KTL } \\
\text { No. } \\
\text { alleles }\end{array}$ & $\mathrm{H}$ & $\begin{array}{l}\text { SHA } \\
\text { No. } \\
\text { alleles }\end{array}$ & $\mathrm{H}$ & $\begin{array}{c}\text { WYT } \\
\text { No. } \\
\text { alleles }\end{array}$ & $\mathrm{H}$ \\
\hline OMM1461 & 5 & 0.500 & 7 & 0.800 & 5 & 0.600 & 4 & 0.778 & 0 & 0.000 \\
\hline OMM1453 & - & - & 7 & 0.800 & 5 & 0.556 & 3 & 0.600 & 4 & 0.900 \\
\hline OMM1462 & 2 & 0.556 & 0 & 0.000 & 3 & 0.500 & 3 & 0.444 & 3 & 0.400 \\
\hline OMM1459 & 4 & 0.700 & 7 & 0.700 & 3 & 0.500 & 3 & 0.400 & 6 & 1.000 \\
\hline OMM1460 & 3 & 0.000 & 4 & 0.400 & 3 & 0.000 & 4 & 0.111 & 3 & 0.200 \\
\hline OMM1478 & 3 & 0.000 & 0 & 0.000 & 2 & 0.000 & 3 & 0.000 & 4 & 0.000 \\
\hline OMM1451 & 3 & 0.400 & 6 & 0.800 & 2 & 0.100 & 3 & 0.400 & 0 & 0.000 \\
\hline OMM1449 & 5 & 0.600 & 9 & 1.000 & 4 & 0.700 & 4 & 0.300 & 1 & 0.000 \\
\hline OMM1483 & 6 & 0.556 & 7 & 0.800 & 6 & 0.900 & 10 & 0.800 & 4 & 0.556 \\
\hline OMM1480 & 3 & 1.000 & 5 & 0.750 & 5 & 0.556 & 7 & 0.800 & 6 & 0.889 \\
\hline OMM1491 & 4 & 0.625 & 6 & 1.000 & 3 & 0.600 & 1 & 0.000 & 2 & 0.000 \\
\hline OMM1476 & 5 & 0.375 & 6 & 0.714 & 5 & 0.500 & 3 & 0.250 & 5 & 0.375 \\
\hline OMM1445 & 7 & 0.600 & 7 & 0.200 & 5 & 0.300 & 10 & 1.000 & 3 & 0.000 \\
\hline MEAN \pm & & $0.493 \pm$ & & $0.724 \pm$ & & $0.447 \pm$ & & $0.453 \pm$ & & $0.393 \pm$ \\
\hline SE & 4.2 & 0.103 & 6.5 & 0.071 & 3.9 & 0.076 & 4.5 & 0.09 & 3.7 & 0.119 \\
\hline
\end{tabular}


Table 9. Mean Heterozygosity Within Each Strain of Rainbow Trout

\begin{tabular}{|ccccc|}
\hline Strain & Observed & SE & $\begin{array}{c}\text { Hardy Weinberg } \\
\text { expected }\end{array}$ & SE \\
\hline ARL & 0.576 & 0.089 & 0.644 & 0.06 \\
\hline BS & 0.665 & 0.073 & 0.681 & 0.049 \\
\hline CR & 0.547 & 0.095 & 0.709 & 0.049 \\
\hline EL & 0.535 & 0.068 & 0.716 & 0.048 \\
\hline EN & 0.397 & 0.103 & 0.588 & 0.067 \\
\hline ERW & 0.493 & 0.081 & 0.683 & 0.036 \\
\hline KLS & 0.724 & 0.071 & 0.800 & 0.02 \\
\hline KTL & 0.447 & 0.076 & 0.627 & 0.05 \\
\hline SHA & 0.453 & 0.09 & 0.616 & 0.064 \\
\hline WYT & 0.393 & 0.119 & 0.653 & 0.072 \\
\hline mean & 0.523 & & 0.6717 & \\
\hline
\end{tabular}


Table 10. F IS Values for Each Locus Within Each Strain of Rainbow Trout*

\begin{tabular}{|c|c|c|c|c|c|c|c|c|c|c|c|c|}
\hline $\begin{array}{l}\text { Locus } \\
\text { Strain }\end{array}$ & $\begin{array}{c}\text { OMM1461 } \\
\text { Fis }\end{array}$ & HetExp & HetObs & $\begin{array}{c}\text { OMM1453 } \\
\text { Fis } \\
\end{array}$ & HetExp & HetObs & $\begin{array}{c}\text { OMM1462 } \\
\text { Fis }\end{array}$ & HetExp & HetObs & $\begin{array}{c}\text { OMM1459 } \\
\text { Fis }\end{array}$ & HetExp & HetObs \\
\hline ARL & 0.0000 & 5.0000 & 5 & -0.0827 & 7.4211 & 8 & $* *$ & $* *$ & $* *$ & -0.3433 & 7.5700 & 10 \\
\hline BS & 0.1370 & 8.0526 & 7 & 0.1880 & 7.3158 & 6 & 0.3628 & 6.1579 & 4 & -0.1339 & 7.1053 & 8 \\
\hline $\mathrm{CR}$ & - & - & - & 0.6500 & 2.7333 & 1 & 0.1385 & 4.6000 & 4 & 0.0667 & 7.4737 & 7 \\
\hline EL & -0.2135 & 5.0000 & 6 & 0.2000 & 2.4000 & 2 & 0.2727 & 2.6667 & 2 & -0.1250 & 3.5789 & 4 \\
\hline EN & 0.2230 & 7.6316 & 6 & - & - & - & 0.0465 & 4.7895 & 5 & - & - & - \\
\hline ERW & 0.2562 & 6.6316 & 5 & - & - & - & 0.0526 & 4.7647 & 5 & -0.1455 & 6.1579 & 7 \\
\hline KLS & 0.0069 & 8.0526 & 8 & 0.0649 & 8.5263 & 8 & - & - & - & 0.0935 & 7.6842 & 7 \\
\hline KTL & 0.2000 & 7.4211 & 6 & 0.1011 & 5.5294 & 5 & 0.2105 & 6.2632 & 5 & -0.1842 & 4.2632 & 5 \\
\hline SHA & -0.3176 & 5.4118 & 7 & -0.3012 & 4.6842 & 6 & 0.3263 & 5.8235 & 4 & 0.4000 & 6.5263 & 4 \\
\hline WYT & - & - & - & 0.1571 & 7.8421 & 9 & 0.3846 & 6.3684 & 4 & -0.2500 & 8.1053 & 10 \\
\hline $\begin{array}{l}\text { Locus } \\
\text { Strain } \\
\end{array}$ & $\begin{array}{c}\text { OMM1460 } \\
\text { Fis }\end{array}$ & HetExp & HetObs & $\begin{array}{c}\text { OMM1478 } \\
\text { Fis } \\
\end{array}$ & HetExp & HetObs & $\begin{array}{c}\text { OMM1451 } \\
\text { Fis }\end{array}$ & HetExp & HetObs & $\begin{array}{c}\text { OMM1449 } \\
\text { Fis }\end{array}$ & HetExp & HetObs \\
\hline ARL & 0.1743 & 6.0000 & 5 & 1.0000 & 4.0000 & $\mathbf{0}$ & 0.2969 & 7.0000 & 5 & 0.1111 & 2.2000 & 2 \\
\hline $\mathrm{CR}$ & 0.3533 & 9.1053 & 6 & 1.0000 & 6.5263 & $\mathbf{0}$ & -0.1250 & 6.2632 & 7 & 0.2800 & 8.2100 & 6 \\
\hline EL & 0.6327 & 7.8947 & 3 & 1.0000 & 7.1579 & $\mathbf{0}$ & 0.1262 & 5.6842 & 5 & 0.5135 & 8.0000 & 4 \\
\hline EN & 0.8125 & 5.1053 & 1 & 1.0000 & 3.3684 & $\mathbf{0}$ & 0.6400 & 2.6842 & 1 & 0.0588 & 6.3529 & 6 \\
\hline ERW & 1.0000 & 6.9474 & $\mathbf{0}$ & 1.0000 & 5.8947 & $\mathbf{0}$ & 0.0649 & 4.2632 & 4 & 0.1429 & 6.9474 & 6 \\
\hline KLS & 0.3950 & 6.4737 & 4 & - & - & $\mathbf{0}$ & -0.0435 & 7.6842 & 8 & 0.1613 & 8.6842 & 10 \\
\hline KTL & 1.0000 & 6.7368 & $\mathbf{0}$ & 1.0000 & 3.3684 & $\mathbf{0}$ & 0.6400 & 2.6842 & 1 & 0.0308 & 7.2105 & 7 \\
\hline SHA & 0.7778 & 4.2941 & 1 & 1.0000 & 5.6471 & $\mathbf{0}$ & 0.2727 & 5.4211 & 4 & 0.6197 & 7.6316 & 3 \\
\hline WYT & 0.6757 & 5.9474 & 2 & 1.0000 & 7.3684 & $\mathbf{0}$ & - & - & & $* *$ & $* *$ & \\
\hline
\end{tabular}


Table 11. $F_{\text {IS }}, F_{\text {ST, }}$ and $F_{\text {IT }}$ values for Each Microsatellite Locus

\begin{tabular}{c|c|c|c}
\hline Locus & $\mathrm{F}_{\text {IS }}$ & $\mathrm{F}_{\mathrm{ST}}$ & $\mathrm{F}_{\text {IT }}$ \\
\hline OMM1461 & 0.0634 & 0.1222 & 0.1788 \\
\hline OMM1453 & 0.0329 & 0.1897 & 0.2164 \\
\hline OMM1462 & 0.2139 & 0.2111 & 0.3798 \\
\hline OMM1459 & -0.0639 & 0.1523 & 0.0982 \\
\hline OMM1460 & 0.6066 & 0.1530 & 0.6668 \\
\hline OMM1478 & 1.0000 & 0.2062 & 1.0000 \\
\hline OMM1451 & 0.0883 & 0.1030 & 0.1822 \\
\hline OMM1449 & 0.2041 & 0.1597 & 0.3312 \\
\hline OMM1483 & 0.0652 & 0.0927 & 0.1519 \\
\hline OMM1480 & 0.0254 & 0.1732 & 0.1943 \\
\hline OMM1491 & 0.0841 & 0.2559 & 0.3185 \\
\hline OMM1476 & 0.3763 & 0.1721 & 0.4837 \\
\hline OMM1445 & 0.2164 & 0.3640 & 0.2450 \\
\hline mean & 0.2182 & 0.1533 & 0.3380
\end{tabular}


Table 12. Mean Strain FIS Values for Each Strain of Rainbow Trout

\begin{tabular}{cc|} 
Strain & Mean FIS \\
ARL & 0.1238 \\
BS & 0.0651 \\
CR & 0.2657 \\
EL & 0.2396 \\
EN & 0.4206 \\
ERW & 0.2795 \\
KLS & 0.1303 \\
KTL & 0.3225 \\
SHA & 0.2827 \\
WYT & 0.4628 \\
\hline
\end{tabular}


Table 13. Individual Rainbow Trout Assigned Incorrectly to Strain of Origin

\begin{tabular}{|ll|} 
Strain-Indiv & Population assigned \\
\hline BS-1 & Arlee \\
CR-7 & Ennis \\
EN-9 & Erwin \\
ERW-7 & Kamloops Trout Lodge \\
ERW-10 & Ennis \\
KLS-4 & Arlee \\
KTL-6 & Colorado River \\
WYT-2 & Kamloops Trout Lodge \\
\hline
\end{tabular}

Table 14. Genetic Differentiation (Pairwise $F_{S T}$ ) Between Strains of Rainbow Trout

\begin{tabular}{|c|ccccccccc|} 
Strain & ARL & BS & CR & EL & EN & ERW & KLS & KTL & SHA \\
\cline { 2 - 11 } BS & 0.1406 & & & & & & & & \\
CR & 0.1268 & 0.1727 & & & & & & & \\
EL & 0.1667 & 0.1583 & 0.1309 & & & & & & \\
EN & 0.2595 & 0.1872 & 0.1897 & 0.1413 & & & & & \\
ERW & 0.1612 & 0.1370 & 0.1143 & 0.0858 & 0.0642 & & & & \\
KLS & 0.0971 & 0.1049 & 0.1201 & 0.1157 & 0.1360 & 0.0996 & & & \\
KTL & 0.1976 & 0.1744 & 0.1237 & 0.1283 & 0.0678 & 0.0519 & 0.1100 & & \\
SHA & 0.1815 & 0.2132 & 0.1776 & 0.1329 & 0.2583 & 0.1772 & 0.1639 & 0.2219 & \\
WYT & 0.1944 & 0.1845 & 0.1703 & 0.1691 & 0.2559 & 0.1855 & 0.1120 & 0.1833 & 0.2237 \\
\hline
\end{tabular}


Table 15. Genetic Distance Between Strains of Rainbow Trout*

\begin{tabular}{|c|c|c|c|c|c|c|c|c|c|c|}
\hline Population & ARL & $\mathrm{BS}$ & $\mathrm{CR}$ & EL & $\mathrm{EN}$ & ERW & KLS & KTL & SHA & WYT \\
\hline ARL & - & & & & & & & & & \\
\hline $\mathrm{BS}$ & 0.56915 & - & & & & & & & & \\
\hline CR & 0.61711 & 0.63700 & - & & & & & & & \\
\hline EL & 0.62567 & 0.60328 & 0.62905 & - & & & & & & \\
\hline $\mathrm{EN}$ & 0.65178 & 0.53692 & 0.63332 & 0.60807 & - & & & & & \\
\hline ERW & 0.57567 & 0.53978 & 0.58786 & 0.57226 & 0.43855 & - & & & & \\
\hline KLS & 0.55933 & 0.59133 & 0.61440 & 0.64711 & 0.64245 & 0.61936 & - & & & \\
\hline KTL & 0.59673 & 0.57357 & 0.56141 & 0.59104 & 0.48442 & 0.46843 & 0.61722 & - & & \\
\hline SHA & 0.60395 & 0.63379 & 0.62486 & 0.51453 & 0.68715 & 0.61417 & 0.64034 & 0.63313 & - & \\
\hline $\begin{array}{l}\text { WYT } \\
\text { (Biosys } 1.7\end{array}$ & $\begin{array}{l}0.66020 \\
\text { Cavalli-s }\end{array}$ & $\begin{array}{l}0.68177 \\
\text { forza \& E }\end{array}$ & $\begin{array}{c}0.66361 \\
\text { dwards (1) }\end{array}$ & $\begin{array}{l}0.71451 \\
67) \text { chord }\end{array}$ & $\begin{array}{c}0.71280 \\
\text { distance) }\end{array}$ & 0.65904 & 0.65260 & 0.60602 & 0.73634 & - \\
\hline
\end{tabular}

Table 16. Summary of BLAST Searches, Clustered Sequences, and Redundant Clones in Rainbow Trout Expressed Sequence Tags

\begin{tabular}{|l|cccc|}
\hline \multirow{2}{*}{ ID } & Intestine & Kidney & Liver & Ovary \\
\cline { 2 - 5 } No ID & 112 & 45 & 75 & 10 \\
Clusters & 90 & 19 & 6 & 45 \\
Redundant Clones & 29 & 0 & 1 & 11 \\
Novel ESTs & 73 & 25 & 51 & 8 \\
Known ESTs (genes) & 90 & 19 & 6 & 50 \\
\hline
\end{tabular}


Table 17. Summary of Gene Classifications of Rainbow Trout Expressed Sequence Tags [No. Genes (No. Clones)]

\begin{tabular}{|lcccc|}
\hline \multirow{2}{*}{ Binding/transport } & Intestine & Kidney & Liver & Ovary \\
\cline { 2 - 5 } Enzymatic & $20(24)$ & $16(17)$ & $28(59)$ & $3(4)$ \\
Immune system & $27(39)$ & $8(8)$ & $22(23)$ & $1(2)$ \\
Microsatellite & $9(10)$ & $6(7)$ & $4(11)$ & $1(1)$ \\
Miscellaneous & $5(5)$ & $1(1)$ & 0 & 0 \\
Mitochondrial & $8(8)$ & $4(4)$ & $4(5)$ & $3(4)$ \\
Repeat/SINE & $6(6)$ & $2(2)$ & $3(3)$ & 0 \\
Ribosomal & $4(4)$ & 0 & 0 & 0 \\
Structural & $15(15)$ & $4(10)$ & $9(9)$ & $1(2)$ \\
Transcription/translation & $6(6)$ & $1(1)$ & 0 & 0 \\
Unknown function & $12(12)$ & $3(3)$ & $5(5)$ & $1(1)$ \\
\end{tabular}


Table 18. Rainbow Trout Expressed Sequence Tags with Putative IDs Matching Other Species

\begin{tabular}{|l|cccc|}
\multicolumn{1}{l}{ Mammal } & No. clones & No. genes & \% clones & \% within class \\
\cline { 2 - 4 } Human & $\mathbf{7 0}$ & $\mathbf{6 3}$ & $\mathbf{1 6 . 8}$ & \\
Rat & 32 & 29 & 7.7 & 45.7 \\
Mouse & 14 & 12 & 3.4 & 20 \\
Other mammals & 15 & 14 & 3.6 & 21.4 \\
& 9 & 8 & 2.2 & 12.9 \\
Fish sp & & & & \\
O mykiss & $\mathbf{3 1 7}$ & $\mathbf{1 7 7}$ & $\mathbf{7 6 . 2}$ & \\
D rerio & 149 & 55 & 35.8 & 47 \\
Other salmonid & 64 & 56 & 15.4 & 20.2 \\
Other fish species & 47 & 23 & 11.3 & 14.8 \\
I punctatus & 41 & 32 & 9.9 & 12.9 \\
P flesus & 14 & 9 & 3.4 & 4.4 \\
& 2 & 2 & 0.5 & 0.6 \\
Miscellaneous & 14 & 10 & 3.4 & \\
Xenopus sp & 8 & 7 & 1.9 & \\
Chicken & 4 & 3 & 1 & \\
Drosophila sp & 3 & 2 & 0.7 & \\
\hline
\end{tabular}


Table 19. Expressed Sequence Tag Clones Found in Multiple Tissues of Rainbow Trout

\begin{tabular}{|c|c|c|c|c|}
\hline sequence ID & tissue & ID & putative ID & category \\
\hline RTI 16 & $\mathrm{I}, \mathrm{K}$ & AF012125 & beta actin & structural \\
\hline RTI 9, RTK 20 & $\mathrm{I}, \mathrm{K}$ & AF125208 & cytochrome b & mitochondrial \\
\hline CD810907 & $\mathrm{I}, \mathrm{K}$ & U34341 & $28 \mathrm{~S}$ ribosomal RNA & ribosomal \\
\hline BG360528 & $\mathrm{L}, \mathrm{I}$ & AAH42347 & chaperonin subunit 2 (beta) & transcription/translation \\
\hline BG360525 & $\mathrm{L}, \mathrm{I}$ & AAL48192 & cathespin $\mathrm{C}$ & enzymatic \\
\hline BG360527 & $\mathrm{L}, \mathrm{I}$ & $\mathrm{AB} 027708$ & chaperonin & transcription/translation \\
\hline BG360534 & $\mathrm{L}, \mathrm{I}$ & AF157110 & L-plastin & binding/transport \\
\hline BG360526 & $\mathrm{L}, \mathrm{I}$ & AF358667 & procathepsin B & enzymatic \\
\hline BG360533 & $\mathrm{L}, \mathrm{I}$ & AF401559 & ribosomal protein L7 mRNA & ribosomal \\
\hline BG360530 & $\mathrm{L}, \mathrm{I}$ & AF506216 & solute carrier family 25 member 5 & binding/transport \\
\hline BG360541 & $\mathrm{L}, \mathrm{I}$ & AJ315933 & type II keratin E3 & structural \\
\hline BG360547 & $\mathrm{L}, \mathrm{I}$ & AY198323 & dipeptidyl peptidase & enzymatic \\
\hline BG360524 & $\mathrm{L}, \mathrm{I}$ & AY333289 & cathepsin & enzymatic \\
\hline BG360546 & $\mathrm{L}, \mathrm{I}$ & AY357069 & 40S ribosomal protein $\mathrm{S} 30$ & ribosomal \\
\hline BG360548 & $\mathrm{L}, \mathrm{I}$ & AY388590 & 46ii genomic sequence & unknown \\
\hline BG360538 & $\mathrm{L}, \mathrm{I}$ & $\mathrm{BC} 001138.2$ & hexosaminidase A (alpha polypeptide) & enzymatic \\
\hline BG360549 & $\mathrm{L}, \mathrm{I}$ & $\mathrm{BC} 025121$ & serine/cysteine proteinase inhibitor & miscellaneous \\
\hline BG360521 & $\mathrm{L}, \mathrm{I}$ & $\mathrm{BC} 047181$ & ATP-binding cassette & binding/transport \\
\hline BG360542 & $\mathrm{L}, \mathrm{I}$ & $\mathrm{BC} 055257$ & septin & binding/transport \\
\hline BG360535 & $\mathrm{L}, \mathrm{I}$ & P19179 & fimbrin & binding/transport \\
\hline BG360550 & $\mathrm{L}, \mathrm{I}$ & Q00796 & sorbitol dehydrogenase & enzymatic \\
\hline BG360544 & $\mathrm{L}, \mathrm{I}$ & XM_233884 & STAGA complex 65 gamma subunit & transcription/translation \\
\hline BG360543 & $\mathrm{L}, \mathrm{I}$ & AF025803 & cyclophilin 1 & enzymatic \\
\hline CD811014 & $\mathrm{L}, \mathrm{I}$ & AF042218 & apolipoprotein A-I-1 & binding/transport \\
\hline RTI 48, CD568259 & $\mathrm{I}, \mathrm{O}$ & D86625 & ferritin $\mathrm{H} 1$ & binding/transport \\
\hline BG360532 & $\mathrm{L}, \mathrm{I}$ & AF074094 & 5' external transcribed spacer $\&$ intergenic spacer region & ribosomal \\
\hline BE669086, BE859126 & $\mathrm{L}, \mathrm{K}$ & AF533016 & hyperosmotic glycine rich protein & binding/transport \\
\hline CD810904 & $\mathrm{I}, \mathrm{L}, \mathrm{K}$ & L29771, NC_ 001717 & mitochondrion complete genome & mitochondrial \\
\hline BG360537, BE859117 & $\mathrm{I}, \mathrm{L}, \mathrm{K}$ & AF361365 & polyubiquitin & binding/transport \\
\hline BG360539, BE859105 & $\mathrm{I}, \mathrm{L}, \mathrm{K}$ & AF401554 & ribosomal protein L3 & ribosomal \\
\hline
\end{tabular}


Figure 1. Genetic Distance Among Strains of Rainbow Trout

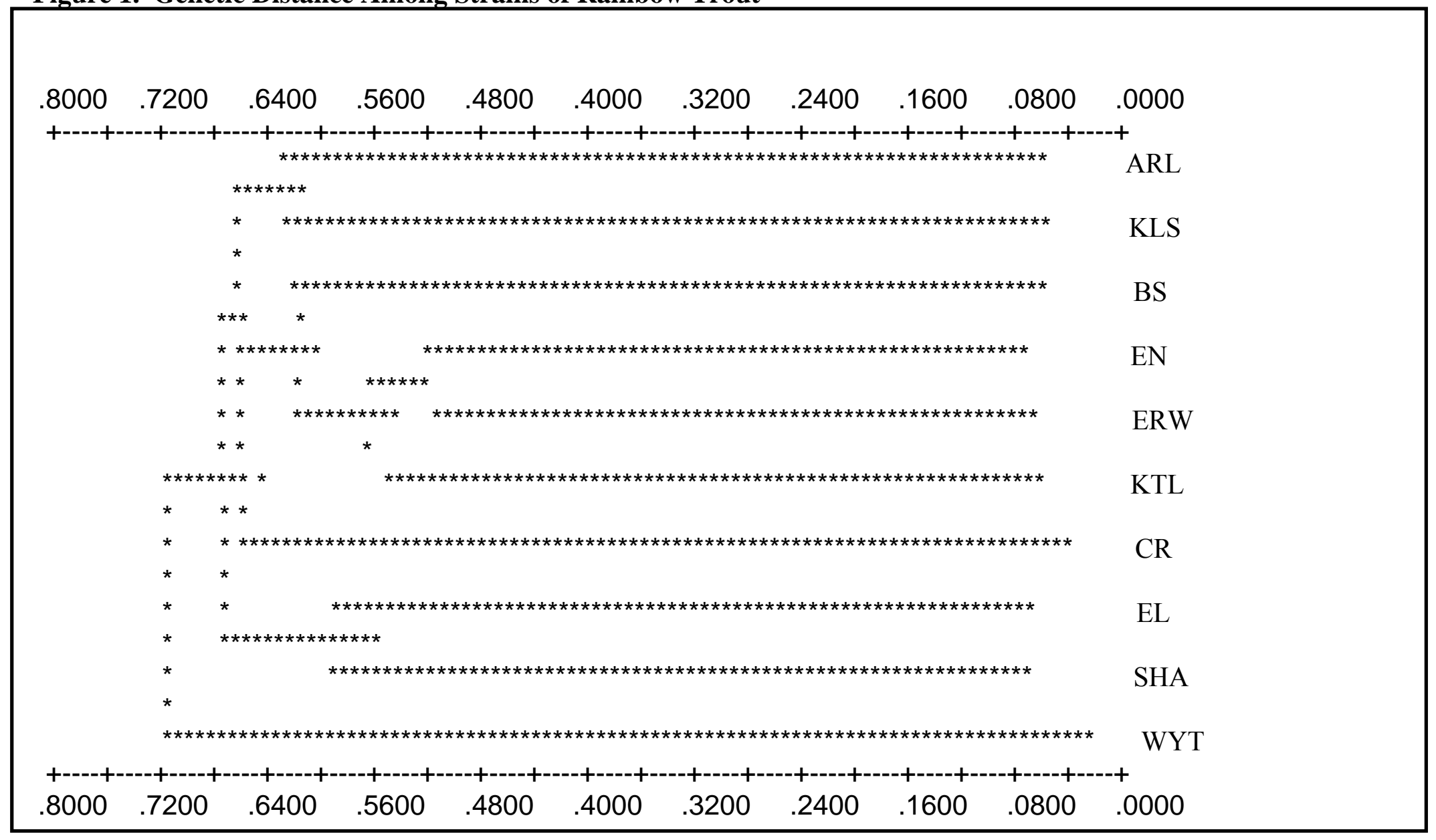


Figure 2. Number of Expressed Sequence Tag Clones in Identification Categories for Evaluated Tissue in Rainbow Trout

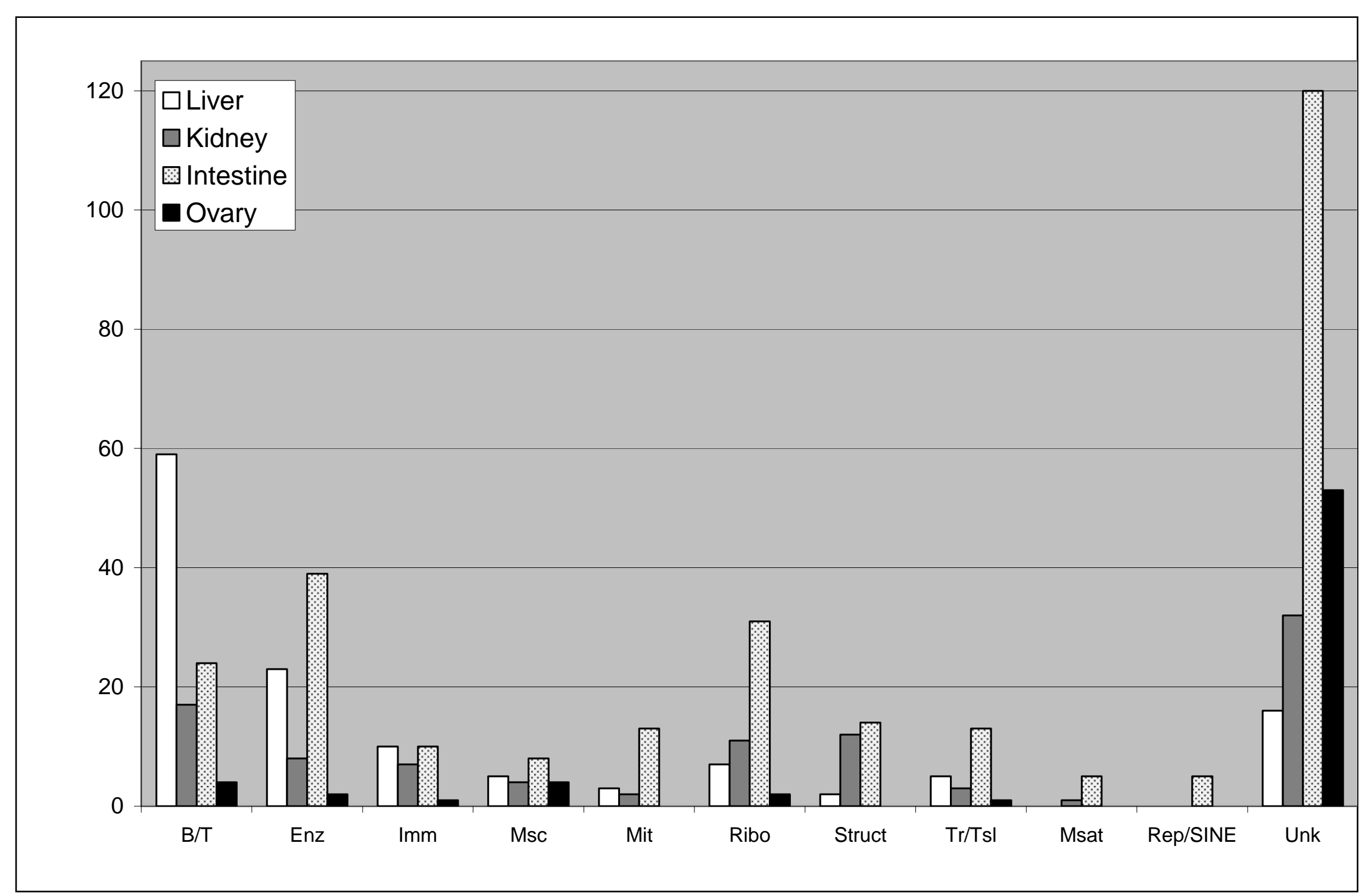


Figure 3. Percentage of Expressed Sequence Tag Clones in Identification Categories for Evaluated Tissue in Rainbow Trout

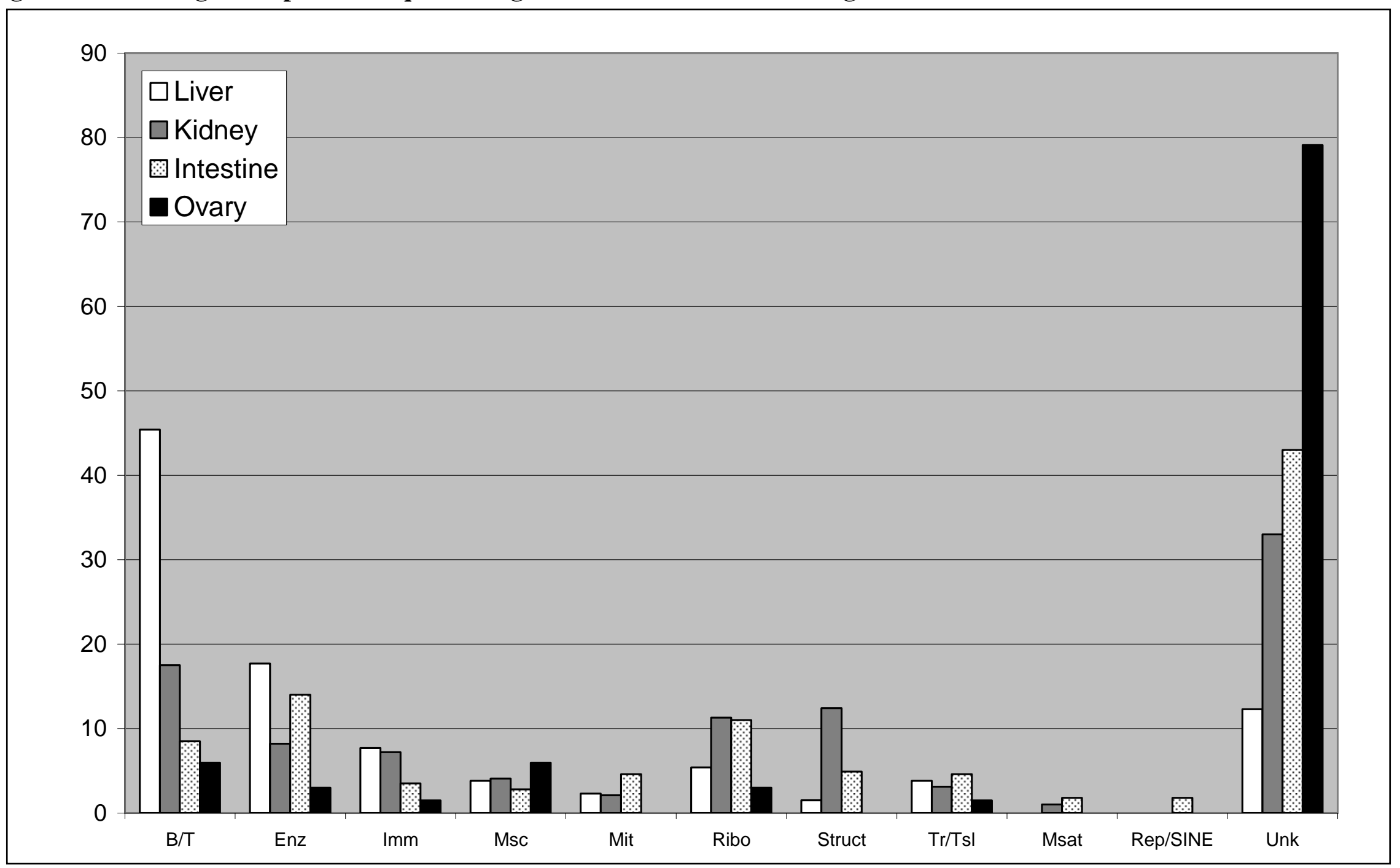


Appendix 1. Genotypes of Individual Rainbow Trout

\begin{tabular}{|c|c|c|c|c|c|c|c|c|c|c|c|c|c|}
\hline $\begin{array}{l}\text { Strain- } \\
\text { Indiv. \# }\end{array}$ & $\begin{array}{c}\text { OMM } \\
1461\end{array}$ & $\begin{array}{c}\text { OMM } \\
1453\end{array}$ & $\begin{array}{c}\text { OMM } \\
1462\end{array}$ & $\begin{array}{c}\text { OMM } \\
1459\end{array}$ & $\begin{array}{c}\text { OMM } \\
1460\end{array}$ & $\begin{array}{c}\text { OMM } \\
1478\end{array}$ & $\begin{array}{c}\text { OMM } \\
1451\end{array}$ & $\begin{array}{c}\text { OMM } \\
1449\end{array}$ & $\begin{array}{c}\text { OMM } \\
1483\end{array}$ & $\begin{array}{c}\text { OMM } \\
1480\end{array}$ & $\begin{array}{c}\text { OMM } \\
1491\end{array}$ & $\begin{array}{c}\text { OMM } \\
1476\end{array}$ & $\begin{array}{c}\text { OMM } \\
1445\end{array}$ \\
\hline ARL-1 & 0405 & 0209 & 0202 & 0109 & 0909 & 0000 & 0606 & 0000 & 1122 & 0909 & 0306 & 0916 & 0606 \\
\hline 2 & 0412 & 0204 & 0202 & 0106 & 0202 & 0303 & 0507 & 0000 & 2222 & 0313 & 0304 & 1616 & 0604 \\
\hline 3 & 0505 & 0709 & 0202 & 0109 & 0202 & 0303 & 0507 & 0314 & 1213 & 0909 & 0304 & 1616 & 0304 \\
\hline 4 & 0505 & 0202 & 0202 & 0106 & 0209 & 0404 & 0606 & 0000 & 1215 & 0000 & 0308 & 0416 & 0108 \\
\hline 5 & 0505 & 0202 & 0202 & 0608 & 0209 & 0303 & 0506 & 0312 & 1516 & 0000 & 0303 & 1314 & 0607 \\
\hline 6 & 0512 & 0712 & 0202 & 0106 & 0209 & 0505 & 0707 & 0000 & 1522 & 0000 & 0306 & 1617 & 0406 \\
\hline 7 & 0507 & 0209 & 0000 & 0609 & 0202 & 0000 & 0606 & 0000 & 1315 & 0000 & 0309 & 1416 & 0611 \\
\hline 8 & 0505 & 0409 & 0202 & 0109 & 0202 & 0404 & 0506 & 0000 & 1522 & 0000 & 0303 & 0411 & 0306 \\
\hline 9 & 0505 & 0204 & 0202 & 0609 & 0409 & 0000 & 0106 & 1414 & 1113 & 0000 & 0306 & 1616 & 0911 \\
\hline 10 & 0512 & 0204 & 0202 & 0809 & 0609 & 0000 & 0707 & 0000 & 0000 & 0000 & 0406 & 0404 & 0308 \\
\hline BS-1 & 0205 & 0411 & 0103 & 0608 & 0000 & 0404 & 0606 & 1414 & 1521 & 0000 & 0000 & 0616 & 0310 \\
\hline 2 & 0105 & 0407 & 0202 & 0608 & 0000 & 0000 & 0607 & 0814 & 2022 & 0000 & 0608 & 0115 & 0408 \\
\hline 3 & 0212 & 0202 & 0103 & 0610 & 0104 & 0404 & 0607 & 0607 & 1515 & 0608 & 0000 & 0616 & 0809 \\
\hline 4 & 0511 & 0411 & 0202 & 0810 & 0909 & 0404 & 0607 & 0410 & 2121 & 0609 & 0310 & 1616 & 0411 \\
\hline 5 & 0211 & 1111 & 0202 & 0106 & 0404 & 0505 & 0707 & 0714 & 1521 & 0606 & 0305 & 0616 & 0303 \\
\hline 6 & 0611 & 0211 & 0202 & 0606 & 0408 & 0404 & 0607 & 0707 & 1521 & 0606 & 0308 & 0716 & 0508 \\
\hline 7 & 0505 & 0202 & 0103 & 0810 & 0409 & 0404 & 0607 & 1014 & 2122 & 1214 & 0305 & 0616 & 0310 \\
\hline 8 & 0505 & 0411 & 0202 & 1010 & 0407 & 0404 & 0607 & 0707 & 1621 & 0606 & 0306 & 0916 & 0210 \\
\hline 9 & 0510 & 0211 & 0303 & 0610 & 0808 & 0404 & 0607 & 1014 & 0000 & 0606 & 0000 & 1016 & 0311 \\
\hline 10 & 1212 & 0404 & 0203 & 0610 & 0000 & 0404 & 0607 & 0714 & 1622 & 0615 & 0000 & 0616 & 0911 \\
\hline CR-1 & - & 0202 & 0000 & 0106 & 0307 & 0303 & 0505 & 1515 & 1318 & - & 0206 & 0000 & 0506 \\
\hline 2 & - & 0202 & 0202 & 0106 & 0408 & 0303 & 0507 & 1118 & 1318 & - & 0206 & 0000 & 0506 \\
\hline 3 & - & 0202 & 0303 & 0101 & 0109 & 0505 & 0707 & 1515 & 1419 & - & 0406 & 1818 & 0613 \\
\hline 4 & - & 0206 & 0203 & 0101 & 0606 & 0202 & 0407 & 0818 & 1321 & - & 0307 & 1818 & 0306 \\
\hline 5 & - & 0000 & 0102 & 0107 & 0909 & 0303 & 0507 & 0911 & 2121 & - & 0205 & 0000 & 0306 \\
\hline 6 & - & 0202 & 0204 & 0708 & 0308 & 0505 & 0709 & 1515 & 1819 & - & 0206 & 0000 & 0313 \\
\hline 7 & - & 0303 & 0202 & 0506 & 0109 & 0505 & 0707 & 1011 & 0808 & - & 0000 & 0218 & 0308 \\
\hline 8 & - & 0202 & 0202 & 0110 & 0408 & 0303 & 0507 & 1111 & 1217 & - & 0208 & 0000 & 0305 \\
\hline 9 & - & 0202 & 0000 & 0110 & 0707 & 0303 & 0507 & 0811 & 2121 & - & 0206 & 2121 & 0608 \\
\hline 10 & - & 0000 & 0203 & 0606 & 0202 & 0202 & 0407 & 0814 & 1821 & - & 0303 & 2121 & 0313 \\
\hline
\end{tabular}




\begin{tabular}{|c|c|c|c|c|c|c|c|c|c|c|c|c|c|}
\hline Strain- & OMM & OMM & OMM & OMM & OMM & $\mathrm{OMM}$ & OMM & OMM & OMM & $\mathrm{OMM}$ & OMM & OMM & OMM \\
\hline Indiv.\# & 1461 & 1453 & 1462 & 1459 & 1460 & 1478 & 1451 & 1449 & 1483 & 1480 & 1491 & 1476 & 1445 \\
\hline EL-1 & 1012 & 0101 & 0202 & 0606 & 1010 & 0303 & 0507 & 0708 & 0202 & 0000 & 0305 & 0518 & 0710 \\
\hline 2 & 1010 & 0000 & 0102 & 0606 & 0909 & 0404 & 0707 & 0606 & 1022 & 0509 & 0406 & 0818 & 0409 \\
\hline 3 & 0510 & 0415 & 0102 & 0606 & 0808 & 0505 & 0707 & 0606 & 1617 & 0815 & 0405 & 0410 & 0610 \\
\hline 4 & 0510 & 0000 & 0101 & 0607 & 0510 & 0303 & 0507 & 0303 & 0521 & 0104 & 0505 & 0404 & 0202 \\
\hline 5 & 1013 & 0109 & 0202 & 0606 & 0808 & 0505 & 0307 & 1515 & 1016 & 0101 & 0303 & 0404 & 0408 \\
\hline 6 & 1010 & 0000 & 0000 & 0608 & 1010 & 0101 & 0306 & 0306 & 0716 & 0108 & 0306 & 0418 & 0606 \\
\hline 7 & 1010 & 0000 & 0000 & 0606 & 0508 & 0505 & 0707 & 0307 & 1021 & 0415 & 0303 & 0303 & 0308 \\
\hline 8 & 0510 & 0000 & 0000 & 0607 & 0511 & 0505 & 0707 & 0317 & 1516 & 0715 & 0505 & 0808 & 0203 \\
\hline 9 & 1010 & 0000 & 0000 & 0608 & 0909 & 0202 & 0405 & 0707 & 2021 & 0108 & 0308 & 1018 & 0306 \\
\hline 10 & 1013 & 0000 & 0000 & 0606 & 0808 & 0505 & 0707 & 0606 & 1522 & 0709 & 0305 & 0810 & 0202 \\
\hline EN-1 & 0510 & 0000 & 0101 & 0000 & 0909 & 0404 & 0606 & 0000 & 1212 & 0117 & 0606 & 0606 & 0309 \\
\hline 2 & 0510 & 0000 & 0202 & 0000 & 0909 & 0505 & 0707 & 1313 & 2121 & 0611 & 0306 & 1212 & 0206 \\
\hline 3 & 0303 & 0000 & 0101 & 0000 & 0808 & 0505 & 0707 & 1314 & 1721 & 0606 & 0606 & 0000 & 0808 \\
\hline 4 & 1010 & 0000 & 0101 & 0000 & 0808 & 0505 & 0707 & 1314 & 0622 & 0306 & 0606 & 0000 & 0303 \\
\hline 5 & 0305 & 0000 & 0102 & 0000 & 0909 & 0404 & 0607 & 1014 & 0622 & 0306 & 0606 & 0606 & 0309 \\
\hline 6 & 0510 & 0000 & 0102 & 0000 & 0808 & 0505 & 0707 & 1013 & 1221 & 0111 & 0606 & 0909 & 0309 \\
\hline 7 & 0310 & 0000 & 0102 & 0000 & 0909 & 0505 & 0707 & 1213 & 2021 & 0106 & 0606 & 1212 & 0513 \\
\hline 8 & 1010 & 0000 & 0102 & 0000 & 0909 & 0505 & 0707 & 1414 & 1220 & 0611 & 0808 & 0606 & 1010 \\
\hline 9 & 0306 & 0000 & 0102 & 0000 & 0109 & 0505 & 0707 & 1013 & 0422 & 0307 & 0606 & 0909 & 0303 \\
\hline 10 & 0909 & 0000 & 0101 & 0000 & 0909 & 0505 & 0707 & 1414 & 1220 & 0106 & 0606 & 0606 & 0309 \\
\hline $\begin{array}{r}\text { ERW- } \\
1 \\
\end{array}$ & 0505 & - & 0102 & 0608 & 0707 & 0303 & 0506 & 1414 & 2222 & 0307 & 0608 & 0916 & 0509 \\
\hline 2 & 1010 & - & 0102 & 0606 & 0909 & 0505 & 0707 & 1319 & 2121 & 0308 & 0608 & 1313 & 0505 \\
\hline 3 & 0305 & - & 0102 & 0808 & 0707 & 0303 & 0507 & 1313 & 2121 & - & 0808 & 0909 & 0707 \\
\hline 4 & 1010 & - & 0101 & 0608 & 0707 & 0505 & 0707 & 1414 & 1523 & - & 0309 & 0609 & 0309 \\
\hline 5 & 1010 & - & 0102 & 0606 & 0909 & 0505 & 0707 & 1314 & 1721 & - & 0909 & 0000 & 0307 \\
\hline 6 & 0510 & - & 0202 & 0608 & 0808 & 0505 & 0607 & 1316 & 1212 & - & 0808 & 1616 & 0303 \\
\hline 7 & 0510 & - & 0000 & 0608 & 0808 & 0404 & 0707 & 1013 & 0000 & - & 0609 & 1618 & 0202 \\
\hline 8 & 0610 & - & 0101 & 0608 & 0707 & 0505 & 0607 & 1414 & 2123 & - & 0306 & 1313 & 0311 \\
\hline 9 & 0505 & - & 0202 & 0708 & 0808 & 0404 & 0707 & 1419 & 2122 & - & 0000 & 0909 & 0305 \\
\hline 10 & 0507 & - & 0102 & 0106 & 0909 & 0505 & 0707 & 1314 & 1721 & - & 0000 & 0000 & 0313 \\
\hline
\end{tabular}




\begin{tabular}{|c|c|c|c|c|c|c|c|c|c|c|c|c|c|}
\hline $\begin{array}{l}\text { Strain- } \\
\text { Indiv. \# }\end{array}$ & $\begin{array}{c}\text { OMM } \\
1461 \\
\end{array}$ & $\begin{array}{c}\text { OMM } \\
1453 \\
\end{array}$ & $\begin{array}{c}\text { OMM } \\
1462 \\
\end{array}$ & $\begin{array}{c}\text { OMM } \\
1459 \\
\end{array}$ & $\begin{array}{c}\text { OMM } \\
1460 \\
\end{array}$ & $\begin{array}{c}\text { OMM } \\
1478 \\
\end{array}$ & $\begin{array}{c}\text { OMM } \\
1451 \\
\end{array}$ & $\begin{array}{c}\text { OMM } \\
1449 \\
\end{array}$ & $\begin{array}{c}\text { OMM } \\
1483 \\
\end{array}$ & $\begin{array}{c}\text { OMM } \\
1480 \\
\end{array}$ & $\begin{array}{c}\text { OMM } \\
1491 \\
\end{array}$ & $\begin{array}{c}\text { OMM } \\
1476 \\
\end{array}$ & $\begin{array}{c}\text { OMM } \\
1445 \\
\end{array}$ \\
\hline KLS-1 & 0510 & 0404 & 0000 & 0606 & 0309 & 0000 & 0306 & 0712 & 1224 & 0505 & 0408 & 0000 & 0808 \\
\hline 2 & 0207 & 0510 & 0000 & 0106 & 0303 & 0000 & 0707 & 0310 & 1621 & 0000 & 0406 & 0505 & 1313 \\
\hline 3 & 0212 & 0413 & 0000 & 0609 & 0707 & 0000 & 0507 & 0105 & 0108 & 0000 & 0310 & 0518 & 0909 \\
\hline 4 & 0812 & 0914 & 0000 & 0909 & 0909 & 0000 & 0707 & 0314 & 1213 & 0000 & 0103 & 0516 & 0606 \\
\hline 5 & 0505 & 0213 & 0000 & 0710 & 0309 & 0000 & 0203 & 0305 & 1212 & 1415 & 0308 & 1016 & 0303 \\
\hline KLS-6 & 0505 & 0213 & 0000 & 0606 & 0909 & 0000 & 0207 & 0305 & 1221 & 0000 & 0308 & 0616 & 0303 \\
\hline 7 & 0207 & 0510 & 0000 & 0608 & 0303 & 0000 & 0607 & 1020 & 1224 & 0513 & 0406 & 1616 & 0404 \\
\hline 8 & 0512 & 0404 & 0000 & 0506 & 0909 & 0000 & 0507 & 0512 & 1212 & 0000 & 0810 & 0617 & 0311 \\
\hline 9 & 0507 & 0510 & 0000 & 0610 & 0209 & 0000 & 0508 & 0205 & 0812 & 1014 & 0608 & 0000 & 0608 \\
\hline 10 & 0506 & 0413 & 0000 & 0109 & 0309 & 0000 & 0307 & 0510 & 1213 & 0000 & 0608 & 0000 & 0303 \\
\hline KTL-1 & 0512 & 0202 & 0102 & 0606 & 0909 & 0505 & 0707 & 1113 & 2022 & 0107 & 0404 & 1119 & 0203 \\
\hline 2 & 0505 & 0209 & 0101 & 0606 & 0909 & 0505 & 0707 & 1014 & 0721 & 0505 & 0306 & 1111 & 0208 \\
\hline 3 & 0507 & 0902 & 0101 & 0606 & 0909 & 0505 & 0707 & 1314 & 2122 & 0101 & 0606 & 1818 & 0108 \\
\hline 4 & 0307 & 0912 & 0203 & 0606 & 0909 & 0505 & 0707 & 1414 & 2021 & 0000 & 0606 & 1616 & 0303 \\
\hline 5 & 0305 & 0202 & 0102 & 0608 & 0808 & 0404 & 0606 & 1314 & 0722 & 0107 & 0406 & 0000 & 0303 \\
\hline 6 & 1010 & 0207 & 0303 & 0106 & 0707 & 0505 & 0707 & 1111 & 2121 & 0711 & 0606 & 1818 & 0808 \\
\hline 7 & 0303 & 0812 & 0101 & 0606 & 0707 & 0505 & 0707 & 1314 & 0719 & 0507 & 0406 & 1819 & 0909 \\
\hline 8 & 0305 & 0202 & 0203 & 0608 & 0707 & 0404 & 0607 & 1314 & 1922 & 0708 & 0406 & 0000 & 0303 \\
\hline 9 & 0512 & 0202 & 0101 & 0106 & 0808 & 0505 & 0707 & 1111 & 1319 & 0505 & 0304 & 1316 & 0303 \\
\hline 10 & 0505 & 0000 & 0102 & 0106 & 0707 & 0505 & 0707 & 1314 & 2122 & 0101 & 0406 & 1118 & 0101 \\
\hline SHA-1 & 0505 & 0204 & 0202 & 0707 & 0808 & 0404 & 0607 & 0606 & 1012 & 0815 & 0303 & 0520 & 0108 \\
\hline 2 & 0512 & 0204 & 0202 & 0607 & 0505 & 0303 & 0507 & 0306 & 2222 & 0505 & 0303 & 2020 & 0107 \\
\hline 3 & 0510 & 0413 & 0103 & 0707 & 0707 & 0303 & 0507 & 1515 & 0510 & 1518 & 0303 & 0505 & 0406 \\
\hline 4 & 0510 & 0204 & 0102 & 0101 & 0808 & 0505 & 0707 & 0303 & 1017 & 0508 & 0303 & 0404 & 0103 \\
\hline 5 & 0512 & 0204 & 0202 & 0707 & 0000 & 0505 & 0707 & 1515 & 0910 & 0815 & 0303 & 0520 & 0507 \\
\hline 6 & 0512 & 0404 & 0000 & 0606 & 0808 & 0303 & 0505 & 2121 & 1617 & 0516 & 0303 & 2020 & 0406 \\
\hline 7 & 0507 & 0404 & 0101 & 0107 & 0811 & 0303 & 0505 & 2121 & 1616 & 0708 & 0303 & 0000 & 0412 \\
\hline 8 & 0505 & 0404 & 0202 & 0107 & 0808 & 0505 & 0707 & 0321 & 0103 & 0509 & 0303 & 0505 & 0212 \\
\hline 9 & 0000 & 0404 & 0103 & 0607 & 0808 & 0505 & 0707 & 1521 & 1522 & 0505 & 0303 & 2020 & 0108 \\
\hline 10 & 0510 & 0204 & 0103 & 0101 & 0808 & 0000 & 0507 & 1515 & 1016 & 0515 & 0303 & 0000 & 0110 \\
\hline
\end{tabular}




\begin{tabular}{|r|c|c|c|c|c|c|c|c|c|c|c|c|c|} 
Strain- & OMM & OMM & OMM & OMM & OMM & OMM & OMM & OMM & OMM & OMM & OMM & OMM & OMM \\
Indiv. \# & 1461 & 1453 & 1462 & 1459 & 1460 & 1478 & 1451 & 1449 & 1483 & 1480 & 1491 & 1476 & 1445 \\
\hline WYT-1 & 0000 & 0709 & 0303 & 0206 & 0909 & 0404 & 0000 & 1010 & 1221 & 0407 & 0404 & 0000 & 1313 \\
\hline 2 & 0000 & 0212 & 0404 & 0308 & 0707 & 0404 & 0000 & 0000 & 0722 & 0107 & 0303 & 1111 & 0808 \\
\hline 3 & 0000 & 0212 & 0304 & 0607 & 0207 & 0303 & 0000 & 0000 & 0707 & 0204 & 0303 & 0611 & 0707 \\
\hline 4 & 0000 & 0209 & 0304 & 0608 & 0707 & 0606 & 0000 & 0000 & 0707 & 0203 & 0303 & 1119 & - \\
\hline 5 & 0000 & 0912 & 0202 & 0206 & 0707 & 0707 & 0000 & 0000 & 1212 & 0714 & 0303 & 1818 & - \\
\hline 6 & 0000 & 0202 & 0404 & 0207 & 0909 & 0303 & 0000 & 0000 & 0712 & 0207 & 0404 & 0606 & - \\
\hline 7 & 0000 & 0912 & 0203 & 0206 & 0209 & 0707 & 0000 & 0000 & 1212 & 0202 & 0303 & 1616 & - \\
\hline 8 & 0000 & 0709 & 0303 & 0207 & 0909 & 0404 & 0000 & 0000 & 1221 & 0407 & 0404 & 0000 & - \\
\hline 9 & 0000 & 0712 & 0304 & 0408 & 0909 & 0303 & 0000 & 0000 & 1221 & 0107 & 0404 & 1611 & - \\
\hline 10 & 0000 & 0709 & 0303 & 0206 & 0909 & 0303 & 0000 & 0000 & 0000 & 0000 & 0303 & 0606 & - \\
\hline
\end{tabular}

